UNIVERSIDADE DE SÃO PAULO

INSTITUTO DE GEOCIÊNCIAS

\title{
MICROBIOTA FÓSSIL EM SÍLEX DA FORMAÇÃO ASSISTÊNCIA (SUBGRUPO IRATI, PERMIANO, BACIA DO PARANÁ) NO ESTADO DE SÃO PAULO
}

\section{Cleber Pereira Calça}

Orientador: Prof. Dr. Thomas Rich Fairchild

DISSERTAÇÃO DE MESTRADO

Programa de Pós-Graduação em Geologia Sedimentar

\author{
SÃO PAULO
}

2008 
Calça, Cleber Pereira

Microbiota fóssil em sílex da formação assistência (Subgrupo Irati, Permiano, Bacia do Paraná) no Estado de São Paulo / Cleber Pereira Calça. - São Paulo, 2008.

$\mathrm{x}, 80 \mathrm{f}$. : il.

Dissertação (Mestrado) : IGc/USP

Orient.: Fairchild, Thomas Rich

1. Micropaleontologia 2. Petrografia 3 Paleontologia I. Título 


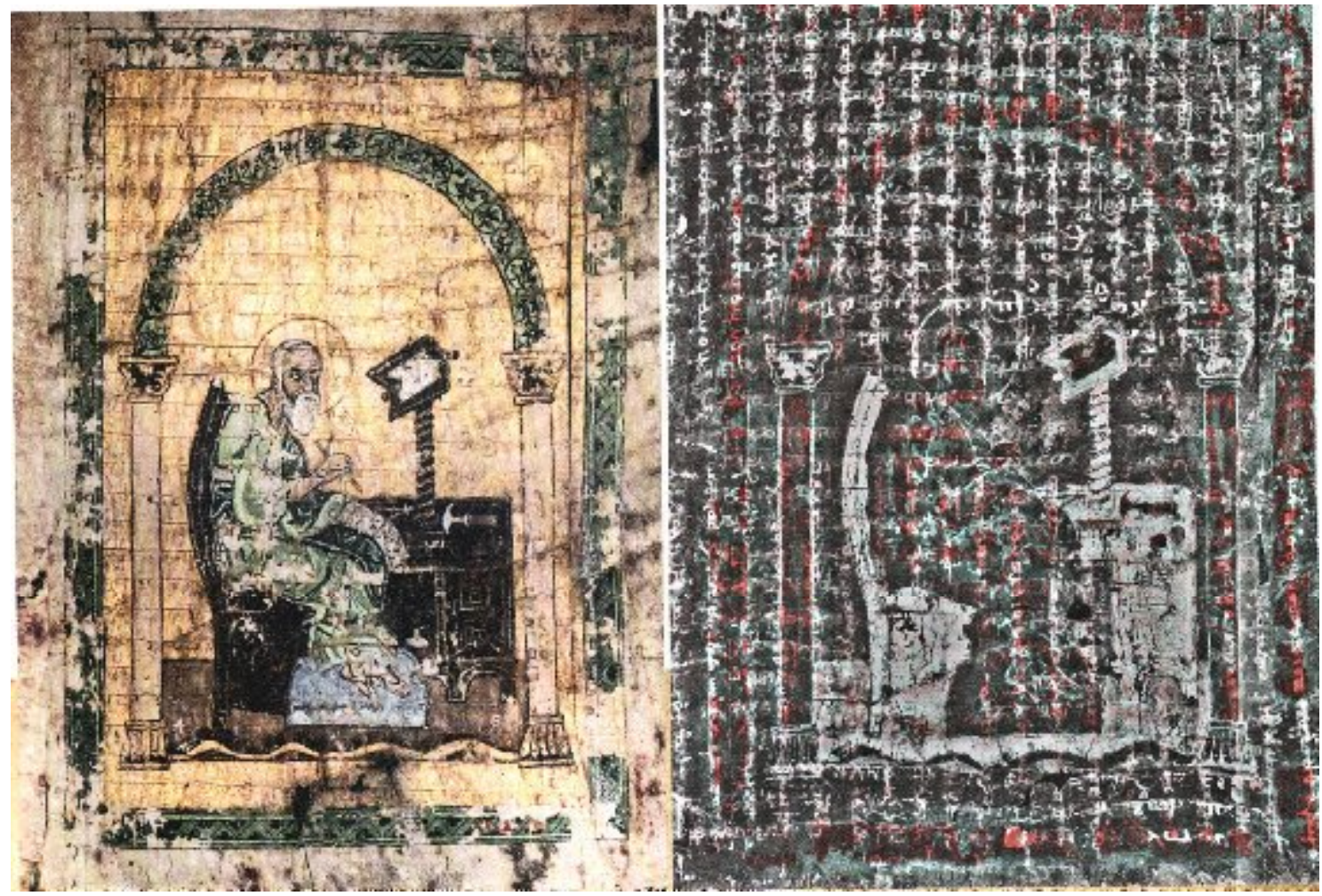

À esquerda desenho bizantino feito em 1940 sobre um pergaminho. À direita uma imagem escaniada por raio-X, feita no laboratório de Radiação Sincrotronica da Universidade de Stanford, E.U.A, que revela dois manuscritos apagados. Um deles, na vertical, é uma cópia, escrita em 975, de um texto de Arquimedes. Em 1229, o texto foi apagado para ser reutilizados por alguém, que depois escreveu na horizontal. Em 1940, o novo texto foi novamente apagado pelo monge que fez o desenho.

O leitor perguntará, inevitavelmente, afinal por que um objeto deste tipo encontrase no começo de uma dissertação sobre paleontologia?

A resposta é uma analogia feita por Hans J. Hofmann, importante paleontólogo que estuda microbiotas fósseis, que comparou o oficio do paleontólogo ao processo utilizado para desvendar o conteúdo deste texto. As letras do pergaminho estavam extremamente pouco legiveis. Mesmo assim, os cientistas, comandados por Reviel Nitz, decifraram o manuscrito, lentamente, letra por letra, revelando informações até então desconhecidas sobre os estudos de Arquimedes, inclusive que os gregos tinham noções sobre o infinito muito avançado para época, não reveladas nos documentos até então disponiveis. Da mesma forma, em paleontologia, temos que lidar com dados muito alterados, mas que revelam como era interessante a vida no passado. 
Se as bactérias tivessem sido descobertas em Marte, sua descrição teria sido muito mais dramática e o caráter bizarro de sua história natural, que amiúde se assemelha à ficção científica, não teria passado despercebido. SORIN SONEIA E MAURICE PANISSET (1983) 


\section{AGRADECIMENTOS}

$\mathrm{O}$ oficio de pesquisador, que desempenhei neste curso de mestrado, me proporcionou o que David Hume considera como os dois mais puros prazeres da vida humana: estudo e convivência social. Fazer ciência é sempre uma experiência humana, e é com grande alegria que relato meus sinceros sentimentos de gratidão a todas as pessoas que estiveram envolvidas no meu curso de mestrado, que marcaram definitivamente minha história pessoal.

Aos pesquisadores que forneceram ensinamentos, questionamentos e apoio acadêmico durante o desenvolvimento desta pesquisa, muitas vezes doando grande esforço e tempo:

- prof. Dr. Jorge Hachiro, cujas pesquisas sobre a sedimentologia do Subgrupo Irati abriram caminho a realização do presente trabalho, mostrando a importância do estudo dos microorganismos no paleoambiente da unidade. Alem disso, ajudou a mim e a meu orientador no primeiro trabalho de campo, observou algumas lâminas delgadas, respondeu diversas dúvidas que tive deu interessantes opiniões sobre meu trabalho.

- prof. Dr. Paulo Alves de Souza, que identificou os grãos de pólen ilustrados nesta dissertação, alem de ter dado diversos e relevantes comentários, que com certeza abriram caminho para pesquisas futuras.

- prof. Dr. André Sawakuchi, prof. Dr. Leônidas Brandes Magalhães e prof. Dr. Marcelo Rocha Corrêa, me ajudaram a entender um pouco de estatísticos, o quê nem sempre é fáceis a um biólogo;

- profa. Dra. Cynthia Moreira Damazio, Me. Anderson Iespa, Me. Cynthia Iespa, prof. Dr. Imre Friedmann; prof. Dr. Aharon Oren e a profa. Dr. Lynn Rothschild pelas dúvidas que me esclareceram sobre a ecologia de microbiotas atuais;

- prof. Dr. Stjepko Golubić que, apesar de ser grandemente respeitado como pesquisador, respondeu diversos correios eletrônicos que lhe enviei, e com grande rapidez e explicações bastante detalhadas, indicando artigos, enviando imagens digitais. Mostrou que alem de saber fazer ciência de qualidade, ama paleontologia e tem muita simpatia e altruísmo.

Aos professores que ministraram as disciplinas de pós-graduação: profs.dr. Marcello Simões, Luiz Eduardo Anelli, Paulo Roberto dos Santos, Paulo César Fonseca Gianinni, Sonny Baxter, Setembrino Petri e Dra. Wania Duleba. 
Aos amigos colegas de curso de pós-graduação, por tudo que aprendi e pelos muitos momentos agradáveis: Rodrigo César Marques, Paula Andréa Sucerquia Rendón, Paula “П”, Fernanda Qualio, Gabriel Luiz Pérez-Vieira, Giselle Utida, Guilheme, Daniel "Pegmatito" Rafael Casati, Milene, Ricardo Pires Domingues, profa. Dra. Wania Duleba, Lucas Veríssimo Warren, Luiz Fernando Zuleta, Renata Hidalgo, Emílio, Fábio Pinheiro, Évelin Sanchez, Milena, Andréia e Juliana.

- Ao funcionário, pelos constantes apoios, competência e amizade: Isaac Sayeg Paula, Magali, Tadeu e Telma, Soninha, Graça, Érika, Brenda, Aline, Luciana, Maria e Sandra, Pedro, Erickson, Josefa e Selina.

Menciono também, com prazer e a devida justiça, em cumprindo uma inexorável obrigação, o imprescindível papel das instituições públicas que estiveram no durante todo o projeto. A saber:

- FAPESP, que me concedeu bolsa de mestrado, acompanhou o desenvolvimento da pesquisa através das avaliações periódicas dos relatórios parciais e deu suporte financeiro na forma de reserva técnica;

- CAPES, que deu suporte financeiro na forma de bolsa e ao $\mathrm{CNPq} /$ monitoria, e do PROAP, que financiou as viagens de campo e as participações em eventos científicos;

- Instituto de Geociências - USP, que forneceu toda a infra-estrutura, como suporte de equipamentos de laboratório e de informática, instalações e pessoal competente.

Seria extremamente injusto não agradecer a toda minha família, em especial aos meus pais Jesus Nazareno Calça e Inez Pereira Calça, os principais responsáveis pela educação e formação humana, que nunca me abandonaram, mesmo nos momentos mais difíceis.

Por fim, sinto grande gratidão por meu estimado orientador, o prof. Dr. Thomas Rich Fairchild, me tanto ensinou nestes anos, cumprindo verdadeiramente o oficio de mestre. Mostrou-me como ter espírito crítico necessário em ciências, exigiu-me um perfeccionismo bem maior do que eu exigia de mim mesmo antes do mestrado, ensinoume que fazer ciência é o exercício do ceticismo, no melhor sentido do termo (skepsis do grego, investigação). Apesar disso, foi uma pessoa extremamente atenciosa e bem humorada, mostrando que é possível ser bom como profissional e pessoa. 


\section{RESUMO}

O estudo de lâminas delgadas de sílex de origem diageneticamente precoce de diversos níveis estratigráficos e localidades da Formação Assistência no Estado de São Paulo revelou pela primeira vez uma assembléia de microorganismos orgânicos delicados, excepcionalmente bem preservados neste importante marco estratigráfico e paleontológico do Neopermiano da Bacia do Paraná. Esta assembléia consiste principalmente de organismos unicelulares, dominados por cianobactérias, tanto solitárias como coloniais, sem nenhum indício de filamentos. Inclui também uma provável clorófita cocoidal, grãos de pólen e fitoclastos, além de alguns microfósseis de afinidades incertas. Estudos paleopalinológicos de resíduos orgânicos desta formação nunca detectaram os elementos delicados desta microbiota. O exame petrográfico permitiu observar não somente todos os microorganismos fósseis em três dimensões no interior da rocha, mas também a distribuição espacial original dos microorganismos e suas relações com os outros componentes da rocha. Isto facilitou a avaliação da variedade morfológica dos microfósseis resultante da degradação e permitiu inferir padrões ontogênicos de alguns dos táxons descritos. Dentre eles, foram reconhecidos 14 morfotipos, reunidos em cinco espécies (todas novas) com afinidades biológicas conhecidas (quatro espécies de cianobactérias e uma clorófita) e cinco táxons incertae sedis (dois novos). A microbiota ocorre principalmente no sílex na base da formação. Constitui massas volumosas e densas preservadas in situ interpretadas como organismos originalmente bentônicos, capazes de formar esteiras microbianas e pequenos estromatólitos. A sedimentologia aliada à ampla extensão geográfica, ao hábito, à abundância e à natureza exclusivamente unicelular dos microorganismos fósseis, alem de exemplos atuais análogos, indicam um paleoambiente aquoso raso de salinidade alta, talvez hipersalina com salinidade variável.

Palavras-chaves: Subgrupo Irati; Permiano; Micropaleontologia; Microbiota fóssil; Lâminas petrográficas. 


\section{ABSTRACT}

The study of petrographic thin sections of early diageneteic chert from diverse levels and localities of the Assistência Formation in the state of São Paulo, Brazil, revealed for the first time an exceptionally well-preserved assemblage of delicate fossil microorganisms in this important stratigraphic and paleontological Early Permian marker unit of the Paraná Basin. This assemblage consists primarily of delicate colonial and solitary unicellular microfossils, dominated by cyanobacteria, without any evidence whatsoever of filamentous microorganisms. It also includes a probable cocoidal chlorophyte, pollen grains and phytoclasts, as well as several less common microfossils of uncertain biological affinity. None of the delicate microfossils of this assemblage have ever been detected in palynological analyses of organic residues from this formation. The study of thin sections made it possible to observe not only all of the fossil microorganisms in three dimensions within the rock but also their original spatial distribution and relationships with other components of the rock. This facilitated evaluation of the morphological diversity of the fossil microorganisms and permitted inferences as to possible ontogenetic patterns. Fourteen morphotypes were recognized among the more delicate microfossils and attributed to five species (all new) of known biological affinities (four species of cyanobacterias and one chlorophyte) and five taxa of Incertae Sedis. The fossil microbiota occurs principally at the base of the formation as dense, voluminous masses interpreted as remains of an in situ benthonic microbiota of photosynthetic microorganisms capable of forming microbial mats and small stromatolites. The sedimentology, together with the widespread distribution, habit, abundance and exclusively unicellular nature of the fossil microorganisms and the paleoenvironmental implications suggested by analogous modern examples, are consistent with a shallow aquatic habitat of high and perhaps variable salinity for the microbiota.

Keywords: Irati Subgroup; Permian; Micropaleontology; Fossil microbiota; Petrographic thin sections. 


\section{SUMÁRIO GERAL}

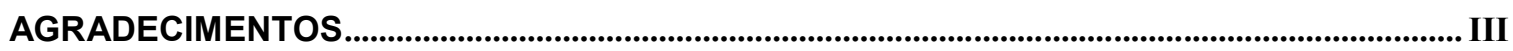

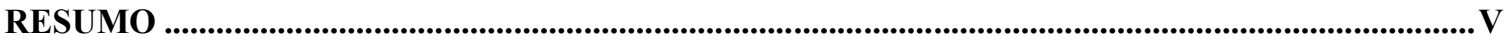

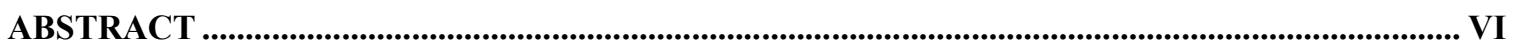

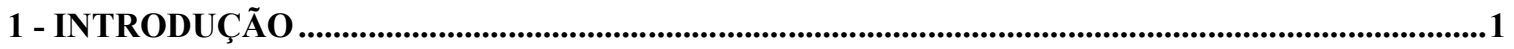

2 - CONTEXTO GEOLÓGICO .....................................................................................................2

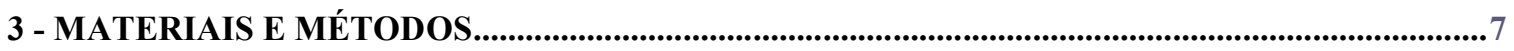

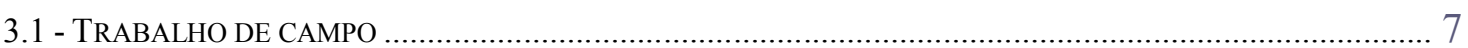

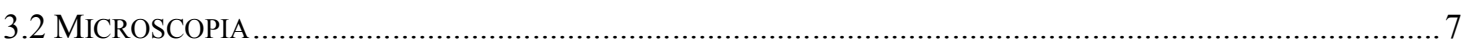

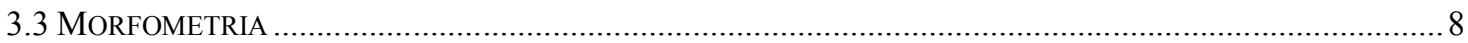

4 - PRINCÍPIOS DE ANÁLISE DE MICROBIOTAS EM SÍLEX .......................................................15

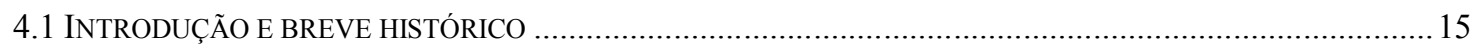

4.2 AVALIAÇÃO DO CONTEXTO SEDIMENTAR/DIAGENÉTICO DAS MICROESTRUTURAS ................................. 17

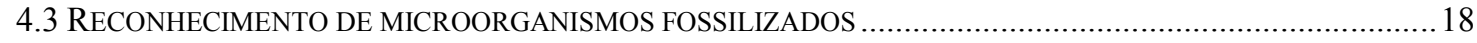

4.4 AVALIAÇÃO DA VARIEDADE MORFOLÓGICA E SUAS CONSEQÜÊNCIAS NA ANÁLISE PALEOBIOLÓGICA. 18

4.6 - CUIDADOS NA INTERPRETAÇÃO DE MICROORGANISMOS FÓSSEIS TRANSPARENTES EM TRÊS

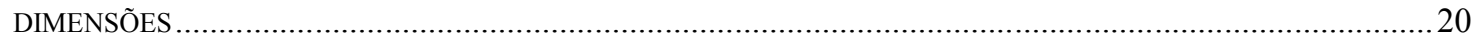

4.6 - DISTINÇÃO ENTRE FÓSSEIS DE CIANOBACTÉRIAS E CLORÓFITAS MICROSCÓPICAS ..............................2

5 - CARACTERÍSTICAS GERAIS DOS MICROFÓSSEIS ENCONTRADOS...................................23

6 - PROBLEMAS DE INTERPRETAÇÃO PALEOBIOLÓGICA ...........................................................30

6.1 - ESPÉCIE 1: NEM GLOEOCAPSOMORPHA PRISCA NEM BOTRYOCOCCUS BRAUNII ................................. 30

6.2 - DIFERENCIAÇÃO ENTRE DOIS MICROORGANISMOS FÓSSEIS MUITO PARECIDOS: GLOEODINIOPSIS SP 1

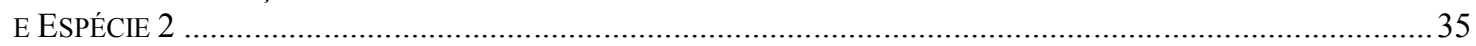

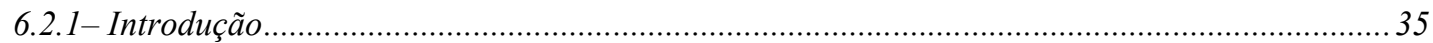

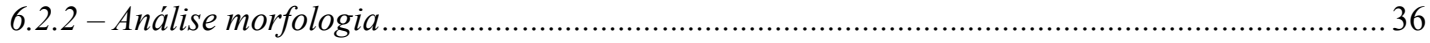

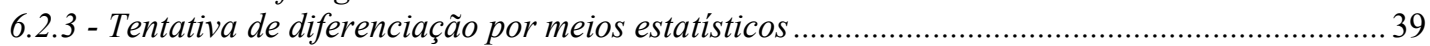

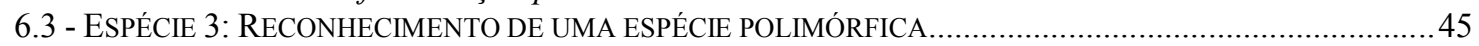

7 - PALEONTOLOGIA SISTEMÁTICA ......................................................................................................48

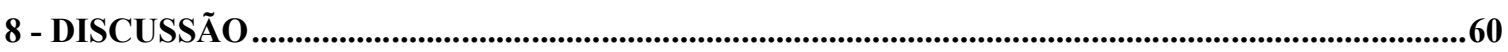

8.1 - CONTRIBUIÇÃO DA UTILIZAÇÃO DE LÂMINAS DELGADAS AO ESTUDO DE

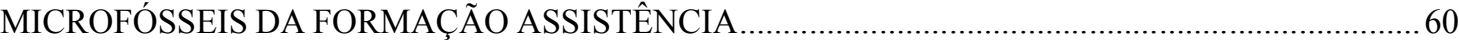

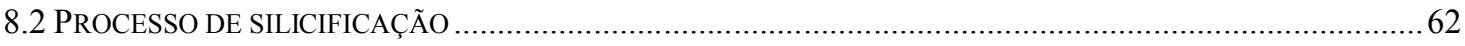

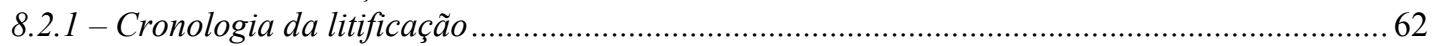

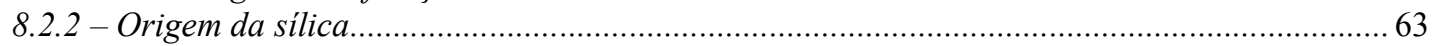

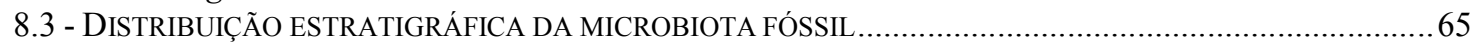

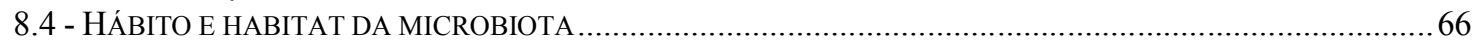

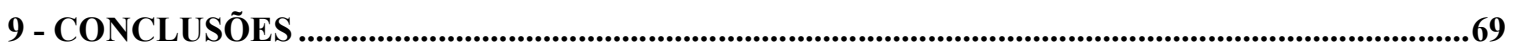

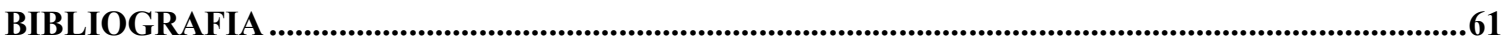




\section{LISTA DE FIGURAS}

Figura 1: Mapa de localização. (a): Faixa aflorante do Subgrupo Iratí (Hachiro 1997) na Bacia do Paraná na América do Sul (Modificado de PAULIPETRO 1981). (b): Localidades na região do Alto Estrutural do Pitanga, centro-leste do estado de São Paulo. (c): Localidades na região de Fartura, próximo do limite com o estado do Paraná..

Figura 2: Distribuição esquemática do Grupo Passa Dois e da parte pós-glacial do Grupo Tubarão na Bacia do Paraná, Brasil (modificada de Santos et al. 2006).

Figura 3: Localidade Paraisolândia 1. Fotomontagem do afloramento que expõe a Camada de Dobras Enterolíticas (Nível 1), Membro Morro do Alto, margem do Córrego Paraisolândiamunicípio de Ipeúna. (a): vista panorâmica. Nota-se o acamamento convoluto e níveis com sílex ao longo de todo o afloramento. (b-e): detalhes de alguns leitos de sílex examinados. (b): dobra em dábliu com núcleo carbonático. (c): parte que parece um dobramento. (d-e): dobras de carbonatos e folhelhos, sendo que os carbonatos estão substituídos por sílex em sua maior parte.(Somente legenda - Imagem Página 10)

Figura 4: Localidade Estrela. Pequeno corte de estrada a norte da Rodovia Alfredo de Oliveira Carvalho (SP 249), região de Fartura, SP. Camada de Dobras Enterolíticas (Níveis 2 e 3), Membro Morro do Alto (a): Vista panorâmica. (b): Nível de carbonato entre camadas espessas de folhelhos. (c-d): detalhe de dobramentos (Imagem Página 11)

Figura 5: Localidade Fartura I. Afloramento intemperizado do lado norte da Rodovia Tomas Magalhães (SP 287), região de Fartura, SP. Camada de Ritmitos Inferiores (Níveis 4 e 5), Membro Morro do Alto. (a): Vista panorâmica. (b-c): Lentes e nódulos de sílex em meio à rocha altamente alterada. (Imagem Página 12)......

Figura 6: Localidade Cruzeiro. (a): vista de todo o Membro Ipeúna. (b): Camada Bairrinho (Níveis 6 - 12), com predomínio de carbonato e estratos milimétricos de folhelho. (c): Camada de Ritmitos Delgados (Níveis 13 - 17), com folhelhos mais espessos e acamamento lenticular. (d): Camada de Ritmitos Superiores (Níveis 18 21), com estratos mais espessos que a camada logo abaixo, e acamamento tabular (Imagem Página 13).....

Figura 7: Diferentes tipos de sílex encontrados na Formação Assistência diagenético (a-b): carbonato com lentes e nódulos - Camada Bairrinho. (b): detalhe de dobramento de sedimento encaixante ao lado de lente. (c): folhelho com lentes e nódulos - Ritmitos Delgados. (d): nódulos em folhelho - Ritmitos Superiores. (e-f): sílex de substituição a carbonato - Camada de Brechas Enterolíticas.

Figura 8: Parâmetros morfométricos: $\mathrm{D}=$ diâmetro; $\mathrm{EB}$ = espessura da bainha; Dmáx = diâmetro máximo; Dmin= diâmetro mínimo; $\mathrm{D} 1$ = diâmetro $1 ; \mathrm{D} 2$ = diâmetro 2. (a): células esféricas. (b): colônia sem forma definida. (c): células subesférica. (d): células hemisferóides. (e): célula cuneiforme. (f-h): orientação das medidas da espessura das bainhas para cada forma celular..

Figura 9: Possíveis vieses ópticos na observação de conjuntos de microorganismos fósseis. À direita, espécimes em orientações não ideais. Observa-se que formas hemisféricas podem parecer esféricas, e células cuneiformes podem se mostrar hemisféricas.

Figura 10: Espécie 1. (a-f): Morfotipo A: colônias com limites celulares indistinguíveis. Setas apontam estruturas esferóides presentes nas extremidades de alguns espécimes. (a,e-f): lâmina GP/L-6E 2; (b): lâmina GP/L-6E 9; (c): lâmina: GP/L-6E 11; (d): GP/L-6E 2. (g-j): Morfotipo B: células esferóides, solitárias ou em colônias de poucos indivíduos. (g): lâmina GP/L-6E 4; (h): lâmina GP/L-6E 11; (i): lâmina GP/L-6E 2; (j): lâmina GP/L-6E 10; (k-o): Morfotipo C: setas indicam bainha colonial fina, com limites bem definidos. (k): colônias com resíduos intracelulares opacos e negros. (1-m): arranjos celulares com células subesféricas, hemisferóides e cuneiformes. (n): dupla de células subesféricas. (o): dupla de células hemisferóides. (k, n-o): lâmina GP/L-6E 2; (l): lâmina GP/L-6E 7; (m): lâmina GP/L-6E 6. Todas espécimes da localidade Paraisolândia 1. Barra $=10 \mu \mathrm{m}$.

Figura 11: Gloeodiniopsis sp 1: células subesféricas, hemisferóides e cuneiformes, todas com parede espessa. (a-d): células subesféricas solitárias. (e-h): duplas de células subesféricas. (i-j): quartetos de células subesféricas. (k-o): células hemisferóides em arranjos de dois, quatro ou oito indivíduos. (p): Conjunto com quatro células cuneiformes. (q-r): quartetos, com arranjo aparentemente planar. Todos os espécimes encontram-se lâminas delgadas de amostras de sílex da localidade Estrela. (a): lâmina; GP/L-6E 22; (b-d): lâmina * GP/L-6E 21. Barra $=10 \mu \mathrm{m}$.

Figura 12: Espécie 2: células agregadas em pacotes. (b-c), (e-f), (g-h), (i-j), (k-l) e (m-o): conjuntos, em diferentes níveis ópticos, com células sobrepostas. No mesmo conjunto, há células com morfologia subesféricas, hemisferóides e cuneiformes. Os espécimes encontram-se lâminas delgadas de amostras de sílex 
da localidade Estrela e Paraisolândia. (a-d): lâmina GP/L-6E 3; (e-f), (i), (p-r): lâmina GP/L-6E 8; (g-h), (j-o): lâmina GP/L-6E 13. Barra $=10 \mu \mathrm{m}$.

Figura 13: Espécie 3. (a-f): Morfotipo D, células solitárias, esféricas, com invólucro composto por uma bainha fina e conspícua entre finas camadas mais opacas. (f): espécime com parte interna do invólucro degradada. (g-j): Morfotipo E, células solitárias, esferóides, com uma região achatada. (k-l): Morfotipo F, células solitárias, subesféricas, com invólucro composto por uma espessa parede celular. (l): seta em região com abertura. Os espécimes encontram-se lâminas delgadas de amostras de sílex das localidades Estrela e Paraisolândia. (a-d): lâmina; GP/L-6E 21; (e, k, l): lâmina GP/L-6E 23; (f, h-j): lâmina GP/L-6E 8; (g): lâmina GP/L-6E 22. Barra $=10 \mu \mathrm{m}$.

Figura 14: (a-d): Gloeodiniopsis aff. G. lamellosa: células com bainha mucilaginosa espessa e colonial, colônia com arranjo planar. Todos os espécimes encontram-se em lâminas delgadas de amostras de sílex da localidade Estrela.. (a): lâmina GP/L-6E 22; (b-d): lâmina GP/L-6E 21. (e-o): Microfósseis Incertae sedis (e-f): Morfotipo G: colônias cubóides aparentemente compostas por duas fileiras adjacentes de células sobrepostas. (e): "vista superior" em relação às fileiras. (f): "vista superior" em relação à fileira. Os espécimes encontram-se lâminas delgadas de amostras de sílex da localidade Estrela. (e): lâmina GP/L-6E 21; (f): lâmina GP/L-6E 17.(g): Morfotipo H: células com bainha com limites bem definidos em colônia aparentemente dispostas em fileiras. Os espécimes encontram-se lâminas delgadas de amostras de sílex das localidades Assistência e Estrela. (g): lâmina GP/L-6E 60. (h-k): Morfotipo I: matéria orgânica opaca de resíduos intracelulares, em agregados irregulares. Possíveis variantes tafonômicas da Espécie 1, da Espécie 2 e de Gloeodiniopsis aff. Lamellosa. Os espécimes encontram-se lâminas delgadas de amostras de sílex da localidade Estrela. (j): lâmina GP/L-6E 21. (k-l): Morfotipo J: células elipsóides aleatoriamente agrupadas, com bainha espessa e descontínua. Os espécimes encontram-se lâminas delgadas de amostras de sílex da localidade Estrela. (k-l): lâmina GP/L-6E 19. (m-n): Morfotipo K: colônia com arranjo "frambóide". O espécime encontra lâmina delgada de amostra de sílex da localidade Paraisolândia. (m-n): lâmina GP/L-6E 2. Barra $=10 \mu \mathrm{m}$.

Figura 15: Outros tipos de microfósseis encontrados. (a): lâmina ${ }^{*} \mathrm{CA} 1$; (b): lâmina GP/L-6E 68; (c-d): Dubiomicrofósseis: possíveis variantes de ciclo de vida Morfotipo $\mathrm{K}$ ou minerais carbonáticos recobertos por matéria orgânica amorfa. lâmina GP/L-6E 2 (e-f): Fitoclástos. (e): lâmina GP/L-6E 68; (f): lâmina GP/L-6E 21. (g-m): Grãos de pólen (g-h): Indeterminados. (g): Lâmina GP/L-6E 49 (h): lâmina GP/L-6E 42.(h-i): em vista equatorial. (i - m): bissacados, característica típica de Gimnospermas. (i): Limitisporites ou Alisporites. Lâmina GP/L-6E 42 (j): provavelmente Limitisporites. Lâmina GP/L-6E 39 (k): Indeterminado. Lamina GP/L-6E 8 (1): provavelmente Lueckisporites. lâmina GP/L-6E 42 (m): Staurosaccites sp em vista polar. Lâmina GP/L-6E; (no) Carapaças incarbonizadas de invertebrados. Lâmina GP/L-6 37 Barra $=100 \mu \mathrm{m}$.

Figura 16: Estromatólito colunar encontrado na localidade Paraisolândia 1.

Figura 17: Reconstituição da ontogenia e da diagenese da Espécie 1. Variedade morfológica muito semelhante à do gênero moderno Gloeocapsopsis. Produtos tafonômicos similares à assembléia de Gloeocapsomorpha prisca da Bacia Baltic (Foster et al. 1989).

Figura 18: Histogramas com freqüência das classes de tamanhos para as quatro espécies descritas de cada uma de suas respectivas variantes morfológicas. Em vermelho, as linhas de tendência.(Figura na pagina 37)

Figura 19:Reconstituição dos padrões de divisão celular das espécies 1 e 2 e Morfotipo G baseada na descrição de Anagnostidis \& Komárek (1988) para cianobactérias dos gêneros Chroococcus, Cyanosarcina e Merismopedia, respectivamente. O símbolo + significa que a ocorrência de dois planos de divisão celular concomitantes. Barra $=10 \mu \mathrm{m}$

Figura 20: Linhas de tendência de valores de diâmetros maiores (em freqüência das classes) para as diferentes morfologias celulares de Gloeodiniopsis sp 1 e da Espécies 2.

Figura 21: Diferentes razões Dmáx/Dmin (células subesferóide e hemisferóides) ou D1/D2 (células cuneiformes) para as três morfologias celulares encontradas na Gloeodiniopsis sp 1 (Sp1) e na Espécie 2 (Sp2)....... 43

Figura 22: Médias aritméticas de Dmáx e o intervalo de confiança de cada população de dados para as variantes de forma celular das espécies 1 e 2 (sp1 e sp2)......

Figura 23: Box-plot do Dmáx das populações de dados da Gloeodiniopsis sp 1 e da Espécie 2.

Figura 24: Histogramas com coleta de dados substitutos, nos quais foram plotados dados escolhidos aleatoriamente e em igual número, referentes às freqüências de classes de tamanho da Gloeodiniopsis sp 1 e da Espécie 2, simulando a situação de que os dados representassem apenas uma espécie. Assim, para os gráficos das formas subesféricas e memisferóides, por exemplo, que têm 54 indivíduos mensurados, 27 pertencem à 
Gloeodiniopsis sp 1 e outros 27 a Espécie 2. Observa-se que nenhum apresenta distribuição normal (monomodal).

Figura 25: Reconstituição do ciclo ontogenético para Espécie 3, que demonstra a formação de zoósporos a partir de possíveis quatro células filhas durante reprodução assexuada. Estruturas listradas não observadas, apenas inferidas.

Figura 26: Imagens de microscopia petrográfica de sílex negro da Formação Assistência. Aspecto marrom da maior parte da área é decorrente da matéria orgânica amorfa, todas da localidade Paraisolândia 1 .(a-i): imagens de lâminas delgadas, nas quais as microestruturas encontram-se in situ, permitindo a observação de materiais mais frágeis. (j-k): imagens obtidas de resíduos orgânicos, ilustrando as microestruturas resistentes ao tratamento químico, como fitoclástos, palinomorfos e grãos de pirita. Lâminas temporárias. (a-e): Diferentes níveis ópticos de uma mesma colônia, imagens que permitem a reconstituição do padrão de divisão celular da espécie. Lâmina GP/L-6E 4 . (f): espécime de Gloecapsomorpha prisca e grãos de pirita, envoltas com matéria orgânica amorfa. Lâmina GP/L-6E 16. (g-i): dois palinomorfos (grãos de pólen bissacados de gimnospermas, em diferentes vistas) e colônias de cianobactérias. Lâmina GP/L-6E 3. (h-i): Detalhe das colônias de cianobactérias

\section{LISTA DE TABELAS}

Tabela 1: Litoestratigrafia do Grupo Passa Dois no estado de São Paulo adotada neste trabalho, modificada de Hachiro (1997) e características litológicas

Tabela 2: Níveis amostrados $(\mathrm{X})$ e dados geográficas das localidades investigadas

Tabela 3: Distribuição qualitativa dos microfósseis ao longo da Formação Assistência. Onde $+=$ Raro; $++=$ pouco; $+++=$ muito; ++++ incontáveis.

Tabela 4: : Síntese dos dados morfológicos e dos táxons reconhecidos. $\mathbf{N}=$ número de indivíduos medidos; Dmáx = diâmetro máxima, $\mathbf{D}=$ diâmetro, $\mathbf{E B}=$ espessura da bainha. 26

Tabela 5: Dados da análise estatística bivariante para formas subesféricas classificadas como Gloeodiniopsis sp 1 e 2. Variáveis: $\mathrm{N}=$ Número de indivíduos, $\mathrm{x}=$ Diâmetro máximo (Dmáx), $\mathrm{y}=$ Diâmetro mínimo (Dmin). $\overline{\mathrm{x}}=$ Média aritmética de Dmáx; $\overline{\mathrm{y}}=$ Média aritmética de Dmin. $a=$ Declive da linha de crescimento. $\sigma_{\mathrm{a}}=$ Desvio padrão de $\mathrm{a} . \mathrm{b}=$ Índice de crescimento. Iniciaḷ. $\alpha\left({ }^{\circ}\right)=$ Ângulo de aclive. $\quad r=$ Coeficiente de correlação de $\mathrm{x}$ e $\mathrm{y} . \mathrm{S}_{\mathrm{x}}=$ Desvio padrão de $\mathrm{x} . \mathrm{S}_{\mathrm{y}}=$ Desvio padrão de $\mathrm{y} . \mathrm{S}_{\mathrm{d}}=$ Desvio padrão da distancia diagonal. $\mathrm{S}_{\mathrm{k}}=$ Desvio padrão da distancia vertical 


\section{ERRATA DOS EXEMPLARES IMPRESSOS}

Aspectos gerais

Nas legendas das figuras $(10,13 ; 14$ e 15$)$ e em algumas partes do corpo do texto (paginas ix; 26, 55) há códigos de lâminas que na verdade estão catalogadas de outra forma. Segue os códigos errados e os respectivos códigos corretos. PAR 2=GP/L-6E 2; PAR 3 A= GP/L-6E 3; PAR $10=$ GP/L-6E 4; PAR 12= GP/L-6E 7; PAR $19=$ GP/L-6E 16; PAR 14= GP/L-6E 9; PAR 31= GP/L-6E 8; *C1A1= GP/L-6E 21; *CA1= GP/L-6E 21; * C1A2= GP/L-6E 22; *C1B= GP/L-6E 23; ASSI 6A= GP/L-6E 65; ASSI 6= GP/L6E 65; CRU 9= GP/L-6E 42; CRU 20= GP/L-6E 37; CRU 27b= GP/L-6E 39; CRU 30 $\mathrm{A}=\mathrm{GP} / \mathrm{L}-6 \mathrm{E}$ 49; PAR 3 1= GP/L-6E 8.

Devido a um engano, não há Tabela 4 no volume final impressos, mas somente na versão em pdf, sendo que a Tabela 5 deveria ser denominada Tabela 4.

\begin{tabular}{|c|c|}
\hline Página & Correção \\
\hline $\mathrm{x}$ & $\begin{array}{l}\text { Na legenda da Figura 26, a espécie Gloeocapsomorpha prisca na verdade é Morfotipo } \\
\text { A. } \\
\text { Legenda da Tabela } 4 \text { é igual a Tabela } 3 \text {. Isso porque não há Tabela } 4 \text { no volume final } \\
\text { impresso da dissertacão, mas somente na versão em pdf. }\end{array}$ \\
\hline 11 & Figuras 4f; 4g; 4h e 4i correspondem, respectivamente, a 4a; 4b; 4c e 4d. \\
\hline 14 & $\begin{array}{l}\text { Na Tabela 2, cédula vazia, acima da cédula onde está escrito Morro do Alto, deveria } \\
\text { conter o nome Membro Morro do Alto. }\end{array}$ \\
\hline 20 & Na primeira frase do item 4.6, não deveria começar com a expressão por outro lado. \\
\hline 22 & $\begin{array}{l}\text { Título do item } 4.7 \text { com numeração e título equivocados, que deveria ser, } \\
\text { respectivamente: } 4.6 \text { - Distinção entre fósseis de cianobactérias e clorófitas } \\
\text { microscópicas unicelulares. }\end{array}$ \\
\hline 24 & $\begin{array}{l}\text { Na primeira linha, trata-se de uma menção a uma seção e não um capítulo. } \\
\text { As figuras que referem aos cinco táxons com afinidades biológicas precisas vão da } 10 \\
\text { até a Figura } 14 \mathrm{~d} \text {, e não apenas as Figuras } 10 \mathrm{e} 14 \mathrm{~d} \text {, como pode parecer. }\end{array}$ \\
\hline 32 & $\begin{array}{l}\text { Na legendas da Figura 14, depois de citar a figura 14f, a expressão correta é "vista } \\
\text { frontal", e não "vista superior". Depois de citar as figuras 14h-k, a intenção foi } \\
\text { especular que o Morfotipo I e um possível variante tafonômica da Espécie 1, da } \\
\text { Espécie } 2 \text { ou de Gloeodiniopsis aff. Lamellosa, e não dos três ao mesmo tempo. }\end{array}$ \\
\hline 35 & $\begin{array}{l}\text { Título do item } 6.2 .2 \text { correto é Análise Morfológica. } \\
\text { Na legenda da Figura 17, se quis dizer produtos e não processo tafonômico. }\end{array}$ \\
\hline 37 & Na legenda da Figura 17, o gênero Merismopedia foi citado inadequadamente. \\
\hline 42 & $\begin{array}{l}\text { Na Figura 20, os valores de } N \text { estão incorretos, os corretos são, para das formas o } \\
\text { táxons Gloeodiniopsis sp 1: Subesféricas }=80 \text {, Hemisferóides }=79 \text { e Cuneiformes }=16 \text {, } \\
\text { e para a Espécie 2: Subesféricas }=27 \text {, Hemisferóides }=21 \mathrm{e} \text { Cuneiformes }=134 .\end{array}$ \\
\hline 43 & $\begin{array}{l}\text { Na legenda da Tabela 5, onde é citado Gloeodiniopsis sp } 1 \text { e 2, deveria ser } \\
\text { Gloeodiniopsis sp } 1 \text { e Espécie } 2 \text {. }\end{array}$ \\
\hline 44 & olo *, que significa valores discrepantes. \\
\hline
\end{tabular}




\begin{tabular}{c|l} 
Página & \multicolumn{1}{c}{ Correção } \\
\hline 48 & $\begin{array}{l}\text { No segundo parágrafo da discussão da Espécie 1, o termo materiais deveria ser } \\
\text { substituído por resíduos internos. }\end{array}$ \\
\hline 49 & $\begin{array}{l}\text { Os primeiros dois parágrafos desta página devem ser excluídos para que a hierarquia } \\
\text { taxonômica seja precisa. }\end{array}$ \\
\hline 54 & Figura referente ao Morfotipo D é a de número 13 a-f. \\
\hline 56 & $\begin{array}{l}\text { No material em que se encontra os espécimes do Morfotipo H, a citação à Lâmina } \\
\text { ASSI 1 deve ser desconsiderada. }\end{array}$ \\
\hline 61 & $\begin{array}{l}\text { No terceiro parágrafo do item 8.1, resíduos orgânicos e lâminas delgadas são citados } \\
\text { como métodos, quando na verdade são materiais. }\end{array}$ \\
\hline 62 & $\begin{array}{l}\text { A citação às Figuras 21j-k, na legenda da Figura 21, diz que em resíduos orgânicos se } \\
\text { observam como fitoclástos, palinomorfos e grãos de pirita. Esta frase não está clara, } \\
\text { deveria ser substituída pela seguinte frase: ... ilustrando as microestruturas resistentes } \\
\text { ao tratamento químico, como fitoclástos, grãos de pólen e pirita. Ainda nesta mesma } \\
\text { legenda, a citação a Gloecapsomorpha prisca na verdade é ao Morfotipo A. }\end{array}$ \\
\hline $\begin{array}{l}\text { As figuras que referem aos cinco táxons com afinidades biológicas precisas vão da 10 } \\
\text { até a Figura 15, e não apenas as Figuras 10 e 15, como pode parecer. }\end{array}$
\end{tabular}




\section{1 - INTRODUÇÃO}

O Subgrupo Iratí, de idade permiana, apresenta importante registro fossilífero bem documentado. Inclui, por exemplo, mesossaurídeos (Oelofsen \& Araújo 1987), palinomorfos (Daemon \& Quadros 1970; Dellazzana 1976; Hart 1971; Santos et al. 2006), estromatólitos (Fairchild et al. 1985) e lenho silicificado (Mussa 1982; Alves 2001). Mesmo assim, somente agora a paleobiologia de sua microbiota fóssil (assembléia de microorganismos fossilizados) começa a ser conhecida.

Uma das litologias mais comuns na unidade e em diversos níveis da bacia, o sílex negro, pela primeira vez foi examinado em lâminas delgadas em um estudo micropaleontológico. Estudos similares são realizados com grande sucesso em sucessões pré-cambrianas, abrindo uma janela para um mundo microbiano surpreendentemente bem preservado, ocupado por bactérias e microalgas (Knoll \& Golubić 1979; Schopf 1995; Knoll 1996). Trabalhos deste tipo são raros em rochas fanerozóicas, que apresentam menor ocorrência de sílex primário (Knauth \& Lowe 2003) e maior variedade e complexidade taxonômica (p.ex. Tobin 2004). Por outro lado, para estudos bioestratigraficos de sucessões fanerozóicas, como a do Subgrupo Irati, é comum dissolver rochas siliciclásticas finas para extrair resíduos orgânicos microfossilíferos para análises palinológicas Contudo, este procedimento destruí microfósseis mais frágeis, como células vegetativas de microalgas e cianobactérias, o que não ocorre em exames petrográficos de rocha microfossilífera (Calça \& Fairchild 2005).

Estudos no Subgrupo Irati e em unidades gondvânicas correlatas mencionam possíveis influencias geológicas dos microorganismos durante a formação desta unidade estratigráfica, como, por exemplo, na origem dos carbonatos (Hachiro 1991) e na formação de hidrocarbonetos (Faure \& Cole 1999). De fato, a presente análise desta assembléia revelou interessantes dados de importância paleoambiental. A pesquisa realizada teve como objetivos: caracterizar a variedade morfológica, elaborar uma taxonomia, identificar o significado paleobiológico, investigar possíveis implicações paleoambientais e determinar a distribuição estratigráfica desta microbiota no Estado de São Paulo. Contribuiu, assim, com o entendimento do paleoambiente da unidade, alem de abrir caminho para estudos futuros. 


\section{2 - CONTEXTO GEOLÓGICO}

A Bacia do Paraná (Figura 1 a) tem natureza intracratônica e ocupa uma área de aproximadamente $1.600 .000 \mathrm{Km}^{2}$, na parte centro-oeste da Plataforma Sul-americana, nos estados do Mato Grosso, Mato Grosso do Sul, Goiás, Minas Gerais, São Paulo, Paraná, Santa Catarina e Rio Grande do Sul, e porções do Paraguai, Uruguai e Argentina. Originou-se no supercontinente Gondvana no Fanerozóico Inferior (Formação Alto da Graça - Ordoviciano). Sua evolução foi bastante influenciada por faixa móvel de sucessivos ciclos orogênicos (Milani \& Thomaz Filho 2000). A primeira superseqüência, chamada Rio Ivaí, representa um evento de glaciação no final do ordaviciano e começo do Siluriano (p.ex. Formação Alto Garças- Ordoviciano Superior - Siluriano Inferior). A superseqüência Gondwana I, é bastante heterogênica, apresenta depósitos glaciogênicos (p.ex. Grupo Guatá - Permiano Inferior), arenitos deltáicos (p.ex. Formação Rio Bonito Carbonífero Superior), siltitos e folhelhos de corpo d'águas profundos (p.ex. Formação Palermo) (Zalán et al.1990; Milani et al. 1994). O Subgrupo Irati marca a passagem da superseqüência Gondwana I para superseqüência Gondwana II, cujo arcabouço estratigráfico é grandemente influenciado por um mar epicontinental de acesso restrito ao oceano (Hachiro et al. 1993). Há uma seqüência regressiva, que começa nos níveis permianos mais recentes (p.ex. Formações Teresina e Rio do Rastro) e culmina com indícios de completo assoreamento do mar epicontinental no Mesozóico (p.ex. Formação Cachoerinha e Grupo Bauru) (Zalán et al.1990; Hachiro 1997, Milani \& Thomaz Filho 2000).

O Subgrupo Irati se destaca neste contexto por sua extensa exposição nas bordas leste e norte da bacia (Figura 2a) e por ser a única unidade da bacia com camadas finas de calcário (Figura 3) (Zalán et al. 1990). É também um importante marco estratigráfico e paleontológico no contexto da Gondvana Ocidental, reconhecido historicamente como elemento fundamental nos argumentos a favor do conceito de deriva continental, sobretudo devido à presença de répteis aquáticos do gênero Mesosaurus, também presente no sul da África. É considerado equivalente estratigráfico das Formações Whitehill na África do Sul; Huab na Namíbia, Port Sussex e do Membro Upper Black Rock, nas Ilhas Malvinas (Horsthemke et. al. 1990; Faure \& Cole 1999), e das Formações Tacuary e São Miguel, no Paraguai (Orué 1996).

A estratigrafia adotada no presente trabalho foi proposta por Hachiro (1997) e formalizado por Hachiro et al. (1993), que elevaram os membros Taquaral 
(predominantemente pelítico) e Assistência (composto principalmente por ritmitos de folhelhos e carbonatos) ao status litoestratigráfico de formação, e foram agrupadas no Subgrupo Irati. Este esquema é facilmente aplicável ao norte do Arco de Ponta Grossa, que inclui o estado de São Paulo, onde a sucessão proposta é contínua e nítida (Tabela 1, Figuras 3-6). Já na porção sul da faixa aflorante, os estratos carbonáticos são mais raros. Conforme Tabela 1 o Membro Morro do Alto (base da Formação Assistência) apresenta, na sua unidade inferior, a Camada de Dobras Enterolíticas, que é a única com acamamento convoluto, composta por folhelhos e carbonatos altamente perturbados. No topo deste membro, encontra-se a Camada Laje Azul, que é composta de folhelhos síltico-argilosos a siltitos arenosas, com acamamente lenticular. $\mathrm{Na}$ base do Membro Ipeúna, há a Camada Bairrinho, que se destaca por ser constituída de um banco carbonático com lâminas pelíticas muito finas. As demais subunidades da formação são compostas por ritmitos de folhelhos e carbonatos que diferem entre si principalmente pela espessura dos estratos, sendo que somente a camada de Ritmitos Delgados apresenta acamamento lenticular, enquanto nas demais o acamamento é tabular.

Sílex de tonalidades geralmente escuras, de cinza a negro, é muito comum na Formação Assistência, tanto nos carbonatos como nos folhelhos. Ocorre de modo descontínuo como lentes e nódulos arredondados, que ganham o apelido de "bonecas de sílex" nos casos de nódulos coalescidos, fenômeno bastante comum nesta formação. Menos freqüentemente, o sílex forma lâminas e camadas finas, mais contínuas.

Esta litologia tem natureza diagenética (Amaral 1971). O sílex negro diageneticamente precoce na Formação Assistência faz com que esta unidade seja um principal jazigo fossilífero do Subgrupo Irati.

O Subgrupo Iratí foi depositado em um corpo d'água de acesso restrito ao oceano, conhecido informalmente por alguns como o "Mar de Iratí" (Milani et al., 1994) e por outros, favoráveis à noção de que a salinidade do corpo provavelmente variava tanto geográfico como temporalmente, como o "Lago-Mar de Iratí" (Petri \& Fulfaro 1983). A abundância de pirita, hidrocarbonetos e querogênio, bem como a falta de bioturbação em grande parte da Formação Assistência indicam condições redutoras no fundo do corpo d'água, inóspitas a organismos bentônicos (Amaral 1971; Subacius \& Amaral 1993; Maynard 1996; Hachiro 1997; Faure \& Cole 1999).

A abundância de querogênio de origem marinha (Amaral 1971; Subacius \& Amaral 1983) indica grande produção de biomassa ficológica. A fauna restrita e a 
ausência de invertebrados marinhos (Mussa 1982; Faure \& Cole 1999) sugerem condições lacustres de salinidades baixas.

O predomínio de folhelhos ao sul do Arco de Ponta Grossa indica que o depocentro encontrava-se nas regiões mais meridionais da bacia, favorecendo ali sedimentação característica de ambiente mais profundo. Seu caráter rítmico evidencia influências paleoclimáticas e astronômicas (ciclos Milankovitch) em sua deposição (Hachiro 1991), sendo que a deposição dos folhelhos teria ocorrido em períodos de águas mais profundas, enquanto os carbonatos teriam se depositado em águas mais rasas. Ciclos eustáticos teriam sido responsáveis pela caracterização de cada subunidade (Hachiro 1997).

Daemon \& Quadros (1970), em pesquisa palinológica pioneira, atribuíram uma idade Induliana (Permiano terminal) para o Subgrupo Iratí, estimada, na época, como entre 250 a 255 milhões de anos. Recentemente, Santos et al. (2006) dataram cinzas vulcânicas no Subgrupo Irati em São Mateus do Sul, PR, pelo método SHRIMP de zircão, e obtiveram idade de 278,4 $\pm 2,2$ milhões de anos (Época Cisuraliana, Idade Artinsquiana). O grande mérito deste trabalho é que o estudo radiométrico foi integrado com a reavaliação bioestratigráfica dos dados palinológicos para esta unidade e seus correlatos no contexto da Gondvana Ocidental. Em outro trabalho recente, Coutinho \& Hachiro (2005) citaram uma idade muito mais nova, de 263 milhões de anos (Limite entre as épocas Lopingiana e Guadalupiana), obtida pelo método U-Pb em zircão de vidro vulcânico, sem mais dados técnicos da análise. 

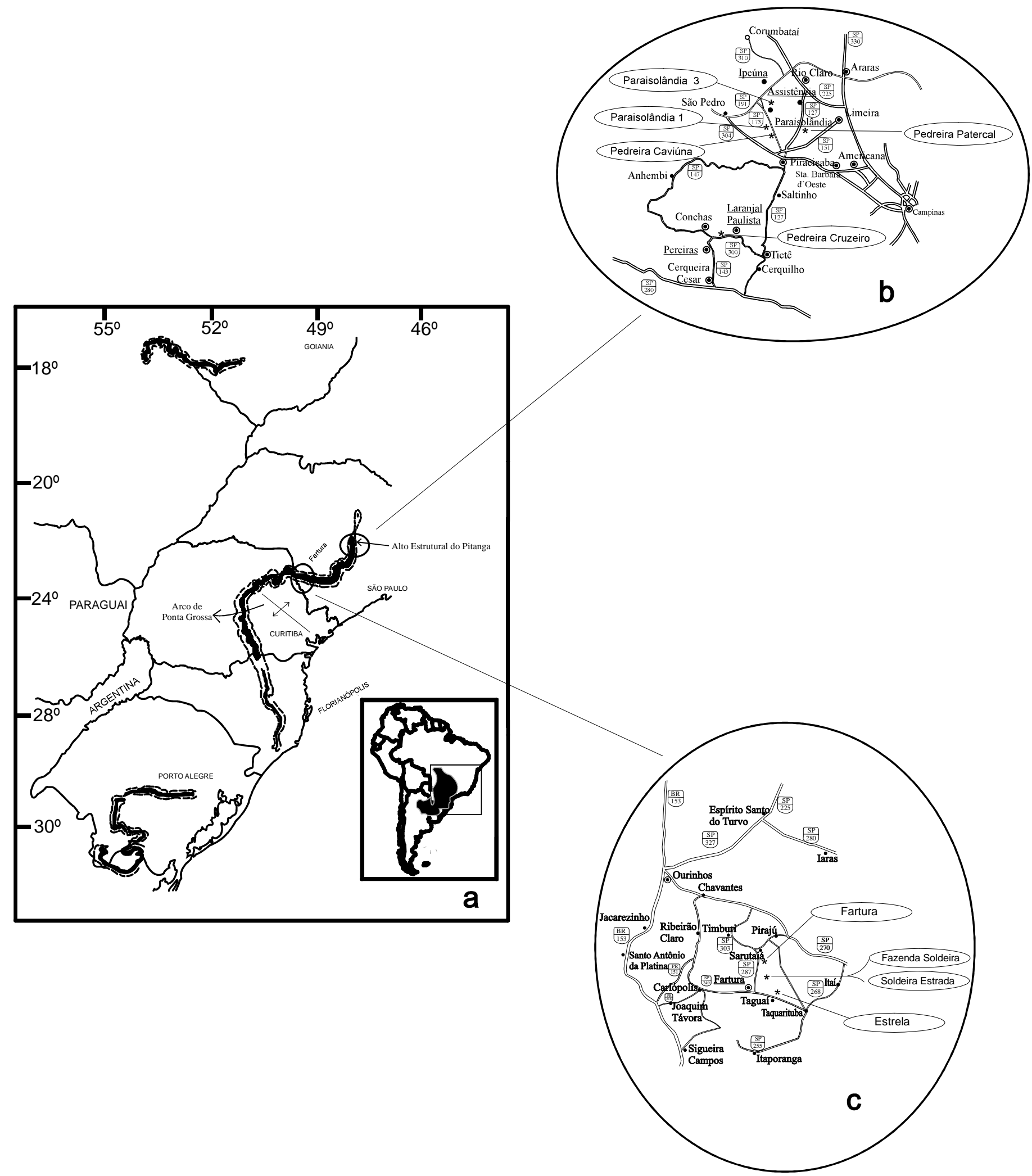

Figura 1: Mapa de localização. (a): Faixa aflorante do Subgrupo Irati Hachiro 1997 (na Bacia do Paraná na América do Sul) Modificado de PAULIPETRO 1981. (b): Localidades na região do Alto Estrutural do Pitanga, centro-leste do estado de São Paulo. (c): Localidades na região de Fartura, próximo do limite com o estado do Paraná. 


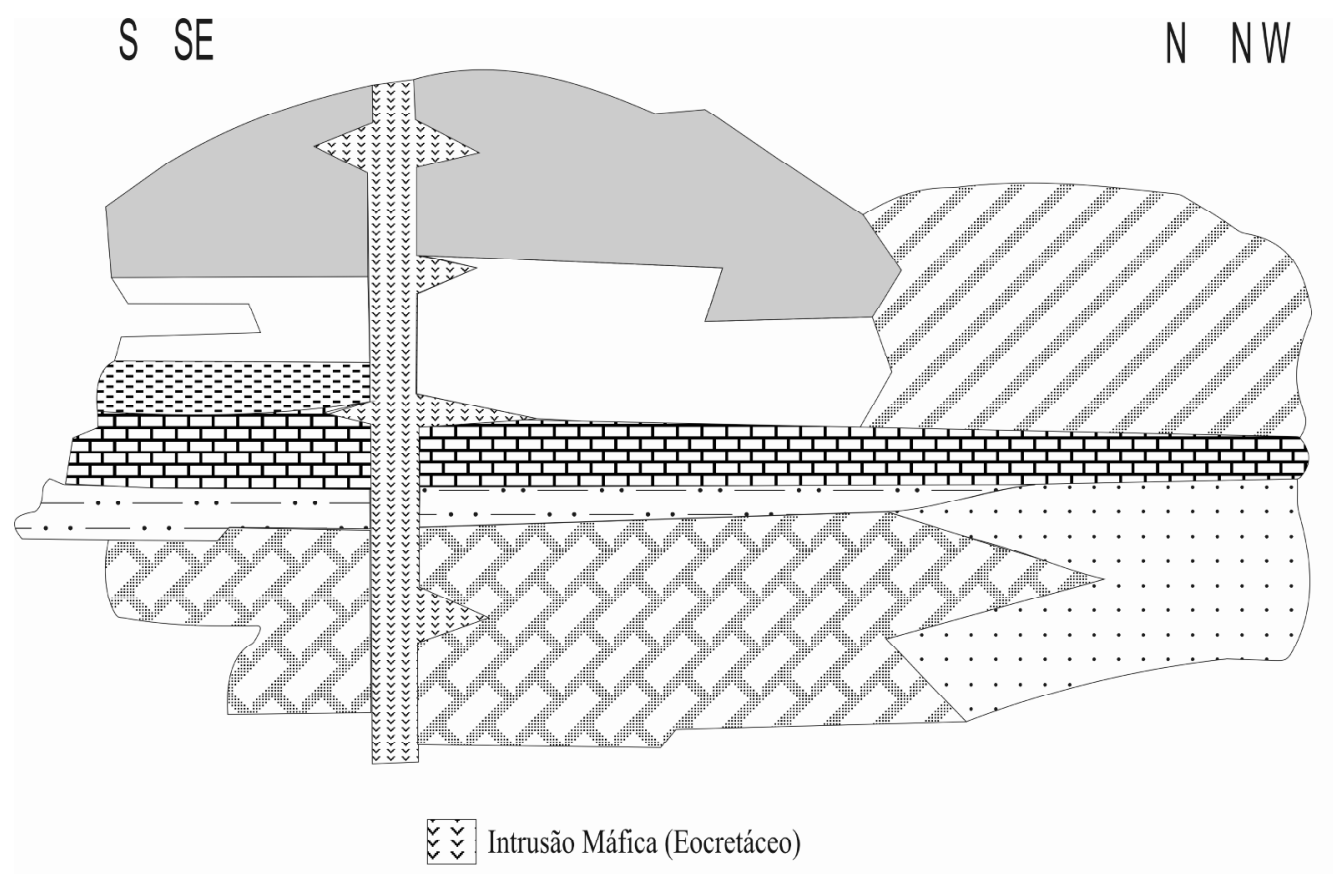

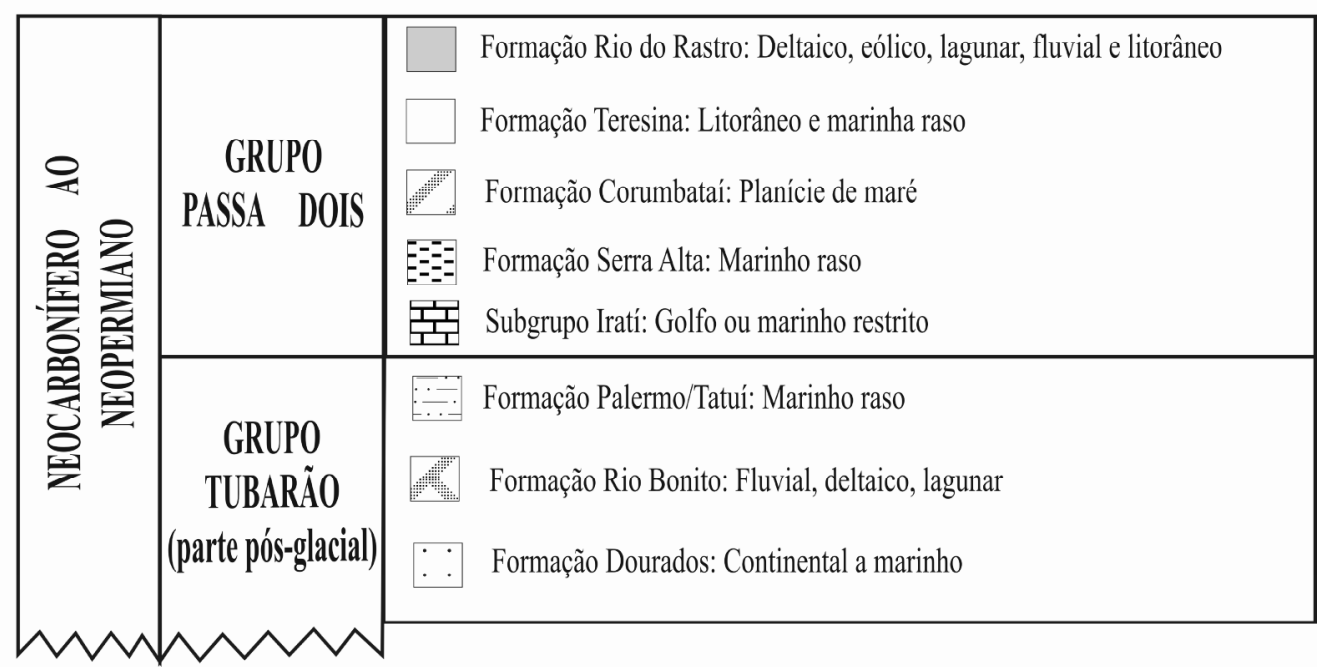

Figura 2 : Distribuição esquemática do Grupo Passa Dois e da parte pós-glacial do Grupo Tubarão na Bacia do Paraná, Brasil (modificada de Santos et al. 2006). 


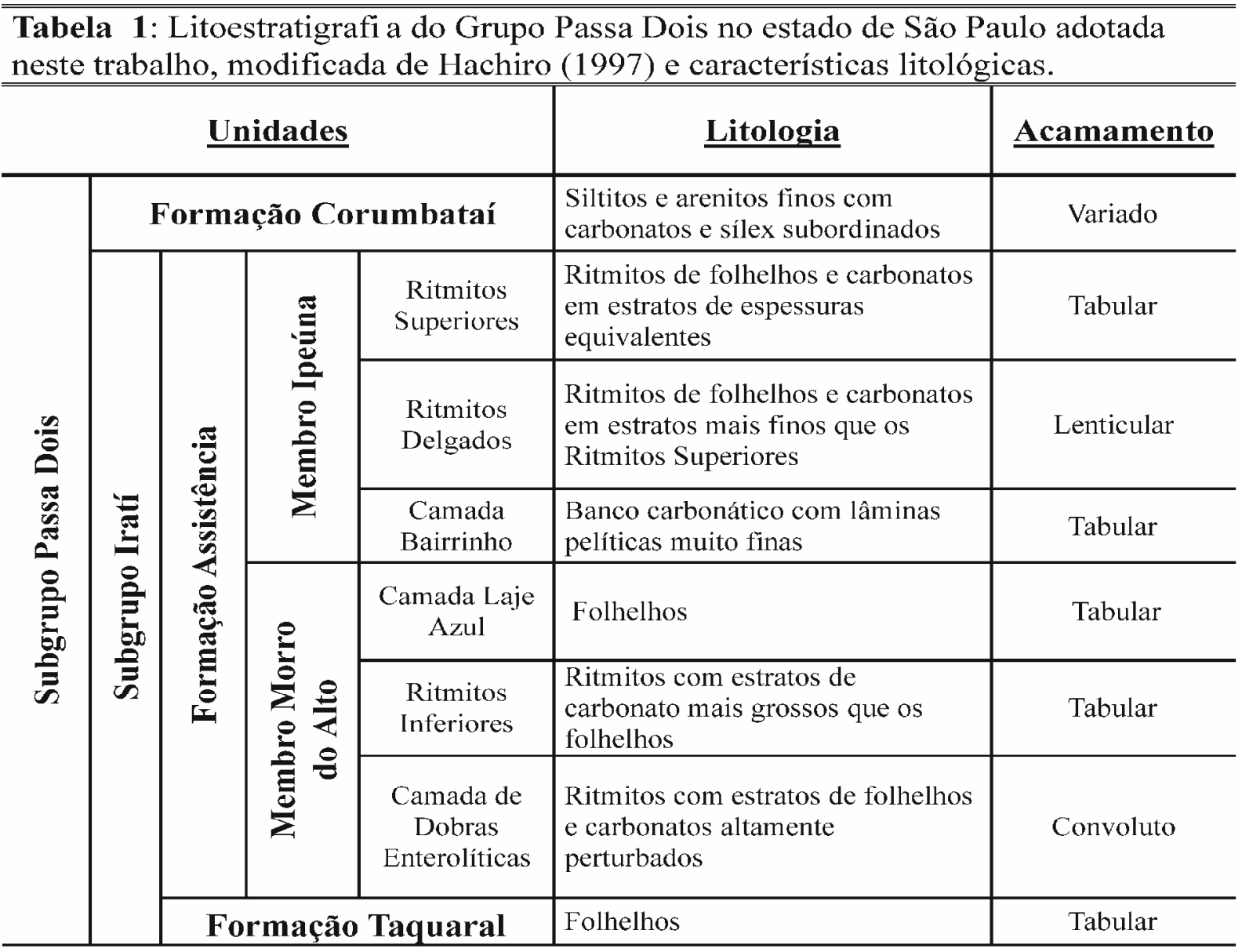

\section{3 - MATERIAIS E MÉTODOS}

\section{1 - Trabalho de campo}

Foram investigadas nove localidades, concentradas em duas regiões do estado de São Paulo, uma na porção centro-leste, que inclui o Alto Estrutural do Pitanga, e a outra em torno da cidade de Fartura, próximo do limite com o Estado do Paraná (Figura 2 bc).

Elaborou-se uma seção composta, na qual os níveis onde se coletaram amostras foram enumerados da base ao topo, totalizando 21 níveis (Figuras 3-6). Todas as amostras continham, pelo menos em parte, sílex negro. A Tabela 2 apresenta as principais informações geográficas e estratigráficas das localidades estudadas em campo. Somente a Camada Laje Azul não foi amostrada, pois raramente é encontrada e/ou reconhecida. 


\subsection{Microscopia}

Confeccionaram-se 66 lâminas petrográficas representativas de quase todas as amostras coletadas. A transparência do sílex permitiu a confecção de lâminas mais espessas (até $80 \mu \mathrm{m})$ do que lâminas petrográficas normais $(30 \mu \mathrm{m})$, o que permitiu observar melhor importantes aspectos sedimentológicos e paleoecológicos.

Para fins comparativos, também foram examinados, em lâminas temporárias, resíduos orgânicos de algumas das amostras de sílex que se mostraram microfossíliferas nos primeiros exames de lâminas delgadas. Os resíduos orgânicos foram obtidos de amostras de rocha fresca através do ataque químico, primeiramente, com ácido clorídrico a $10 \%$, para dissolver o carbonato. Em seguida, o material sobrenadante foi neutralizado por repetidas lavagens com água destilada e decantações. Por fim, os silicatos foram eliminados por ataque químico com ácido fluorídrico a $40 \%$ (ver Uesugui 1979) e o sobrenadante neutralizado.

As lâminas foram examinadas em microscópio petrográfico modelo AxionLab da marca Zeiss, em luz normal e polarizada. Imagens foram obtidas com câmara digital marca Sony, com resolução de 8.0 megapixels, acoplada ao microscópio. Algumas imagens foram digitalmente modificadas posteriormente com os programas AxionVision 4.4 e Corel Photo Paint 12.

\subsection{Morfometria}

Selecionaram-se para medição os espécimes de microorganismos fósseis que não apresentavam alteração tafonômica aparente. A morfologia celular foi classificada como esférica, subesfericas, hemisferóide ou cuneiforme. Os parâmetros medidos variaram de acordo com a forma celular: espessura da bainha (EB); diâmetro celular (D); diâmetro máximo (Dmáx); diâmetro mínimo (Dmin); diâmetro 1 (D1); diâmetro 2 (D2), conforme ilustrada na Figura 8. 
Figura 3: Localidade Paraisolândia 1. Fotomontagem do afloramento que expõe a Camada de Dobras Enterolíticas (Nível 1), Membro Morro do Alto, margem do Córrego Paraisolândia, município de Ipeúna. (a): vista panorâmica. Nota-se o acamamento convoluto e níveis com sílex ao longo de todo o afloramento. (b-e): detalhes de alguns leitos de sílex examinados. (b): dobra em dábliu com núcleo carbonático. (c): parte que parece um dobramento. (d-e): dobras de carbonatos e folhelhos, sendo que os carbonatos estão substituídos por sílex em sua maior parte.

$($ Pagina 11) $\rightarrow$

Figura 4: Localidade Estrela. Pequeno corte de estrada a norte da Rodovia Alfredo de Oliveira Carvalho (SP 249), região de Fartura, SP. Camada de Dobras Enterolíticas (Níveis 2 e 3), Membro Morro do Alto (a): Vista panorâmica. (b): Nível de carbonato entre camadas espessas de folhelhos. (c-d): detalhe de dobramentos.

$($ Pagina 12) $\rightarrow$

Figura 5: Localidade Fartura I. Afloramento intemperizado do lado norte da Rodovia Tomas Magalhães (SP 287), região de Fartura, SP. Camada de Ritmitos Inferiores (Níveis 4 e 5), Membro Morro do Alto. (a): Vista panorâmica. (b-c): Lentes e nódulos de sílex em meio à rocha altamente alterada.

$($ Pagina 13) $\rightarrow$

Figura 6: Localidade Cruzeiro. (a): vista de todo o Membro Ipeúna. (b): Camada Bairrinho (Níveis 6 12), com predomínio de carbonato e estratos milimétricos de folhelho. (c): Camada de Ritmitos Delgados (Níveis 13 - 17), com folhelhos mais espessos e acamamento lenticular. (d): Camada de Ritmitos Superiores (Níveis 18 - 21), com estratos mais espessos que a camada logo abaixo, e acamamento tabular. 


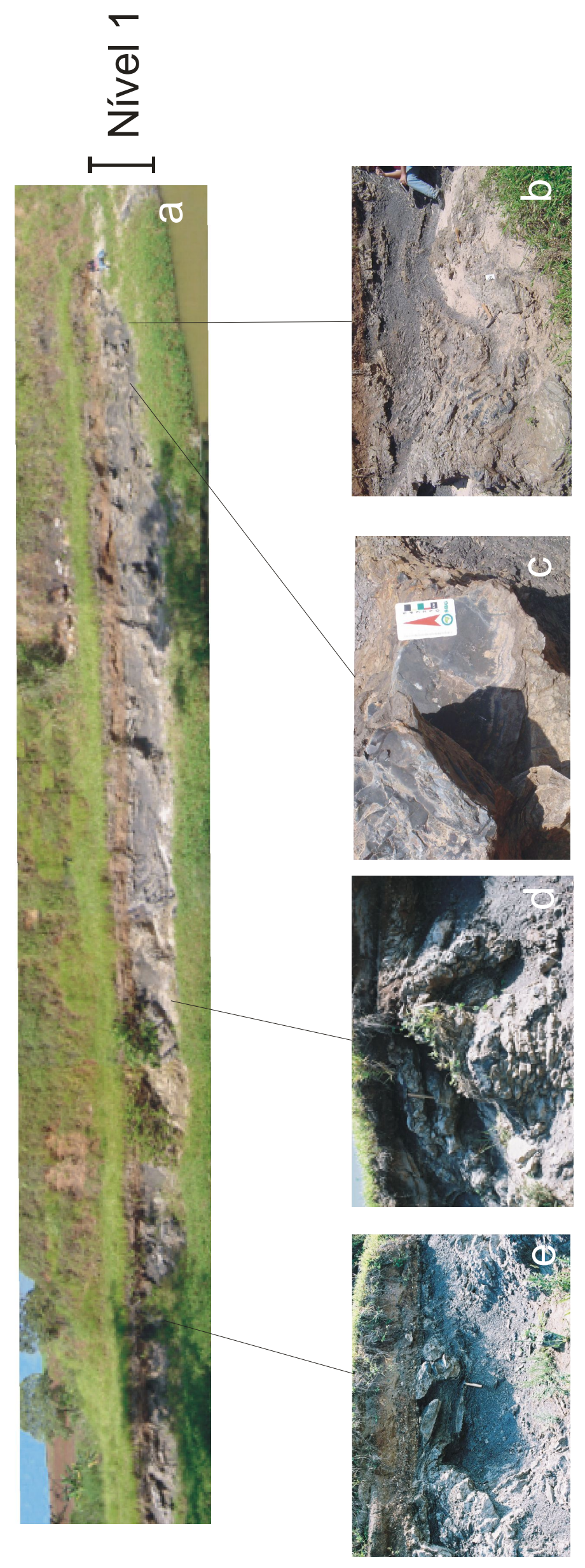




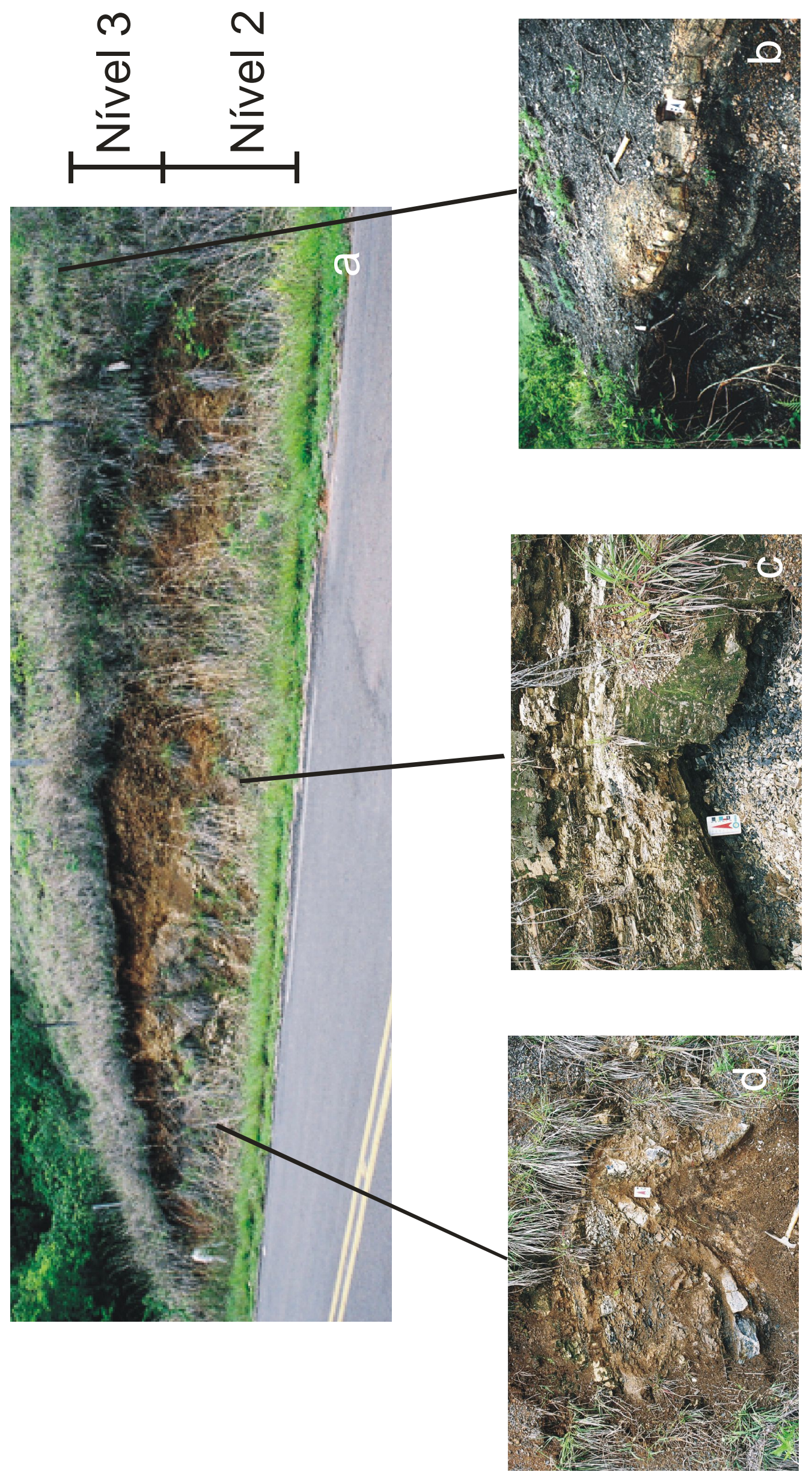



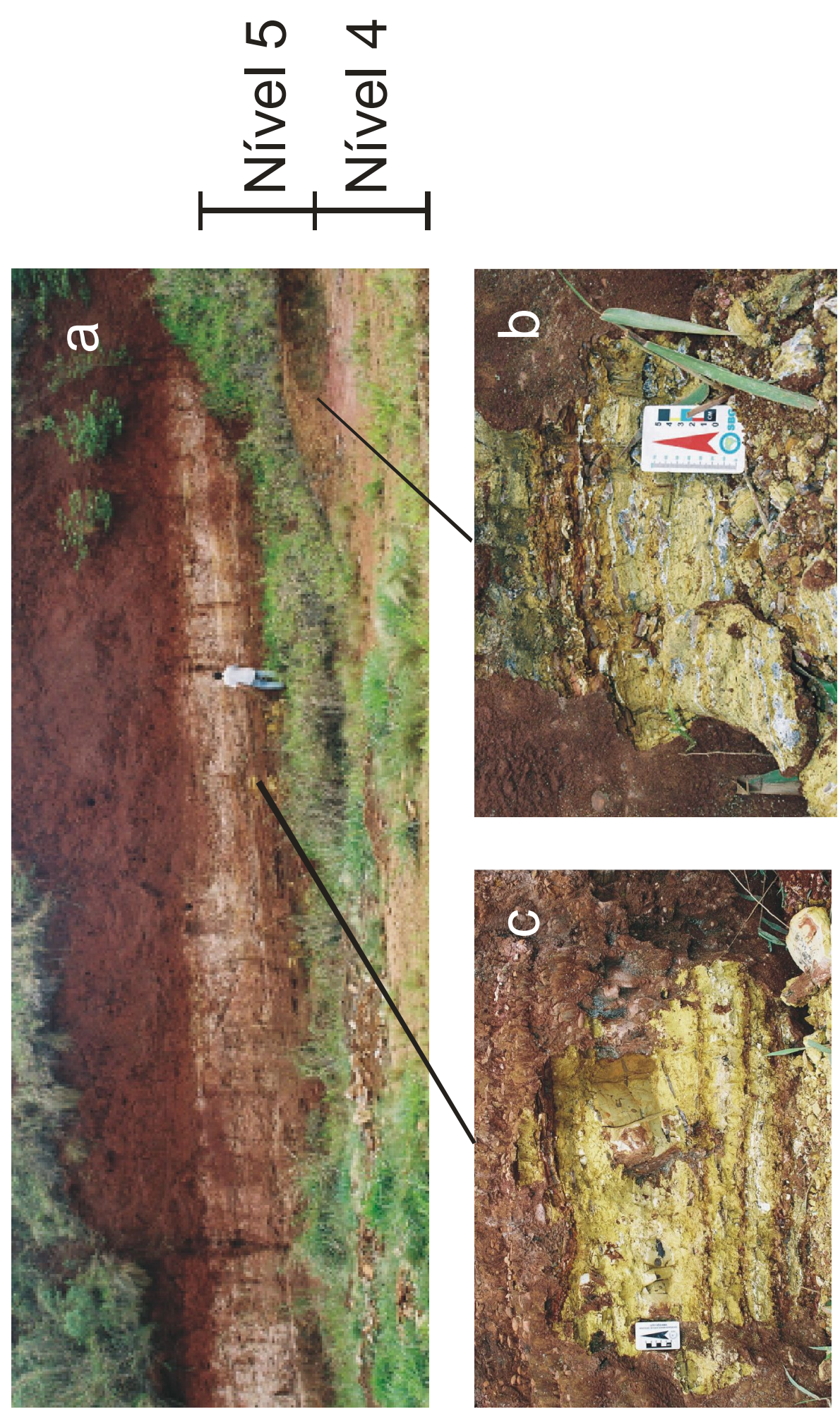

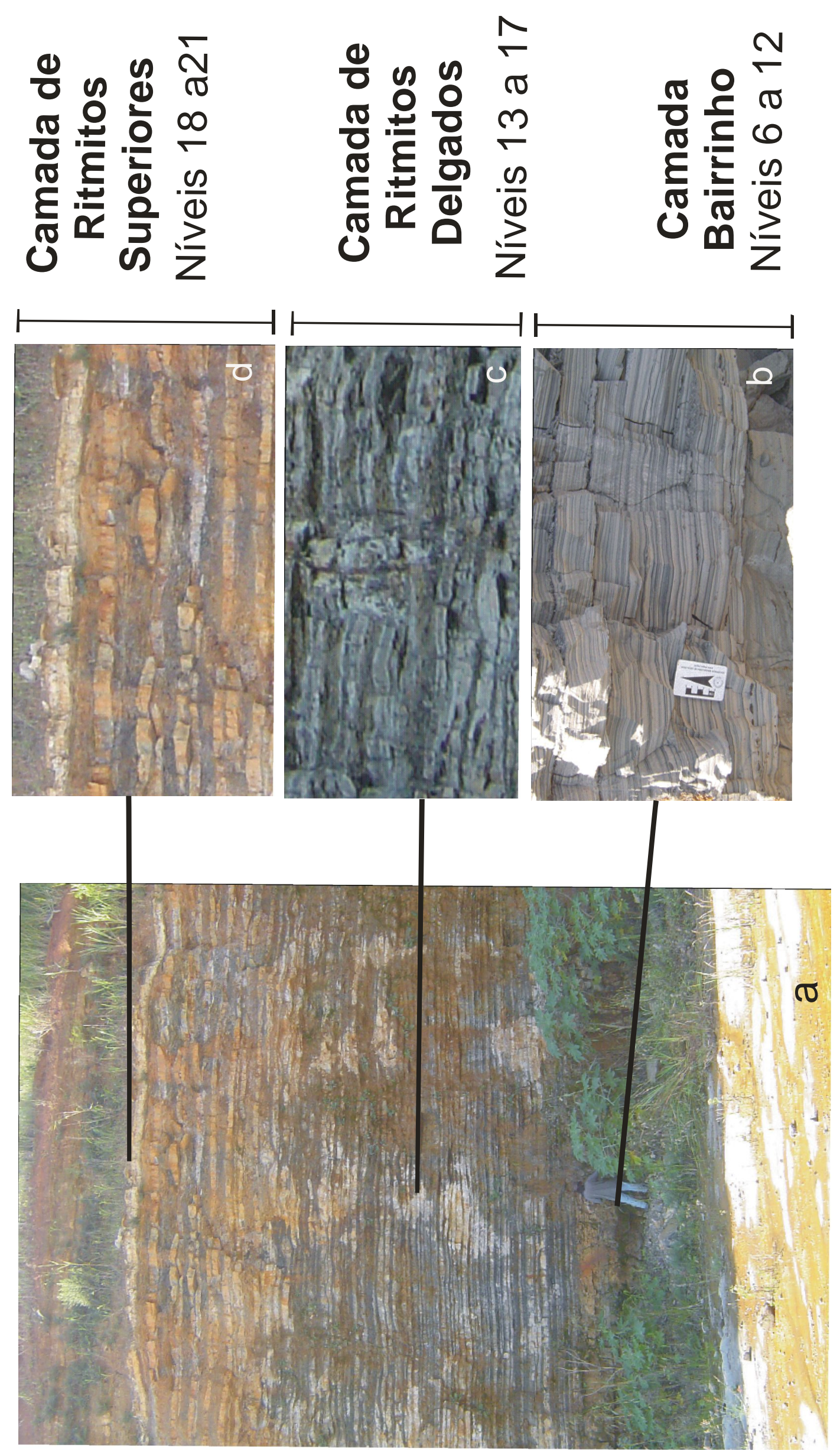


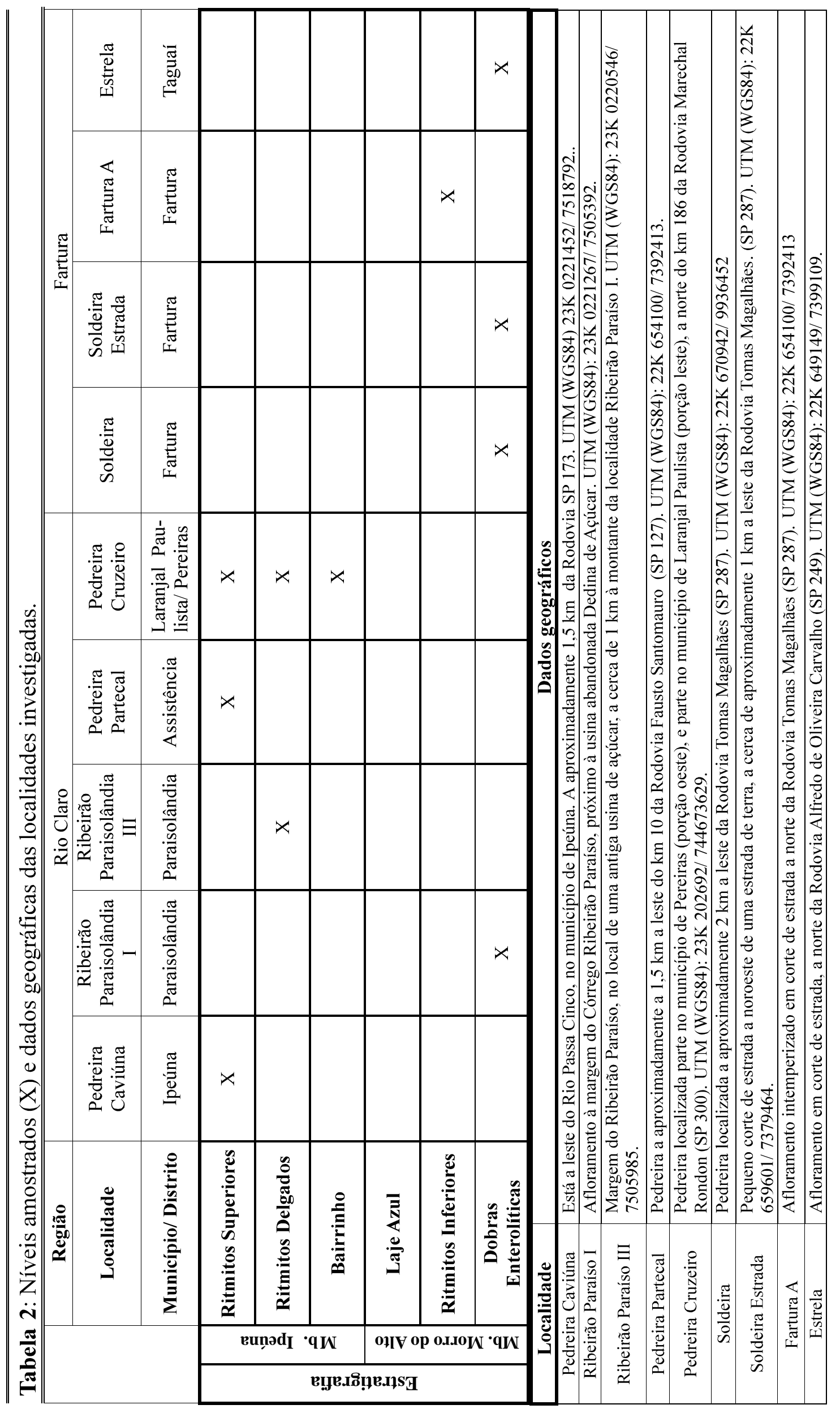



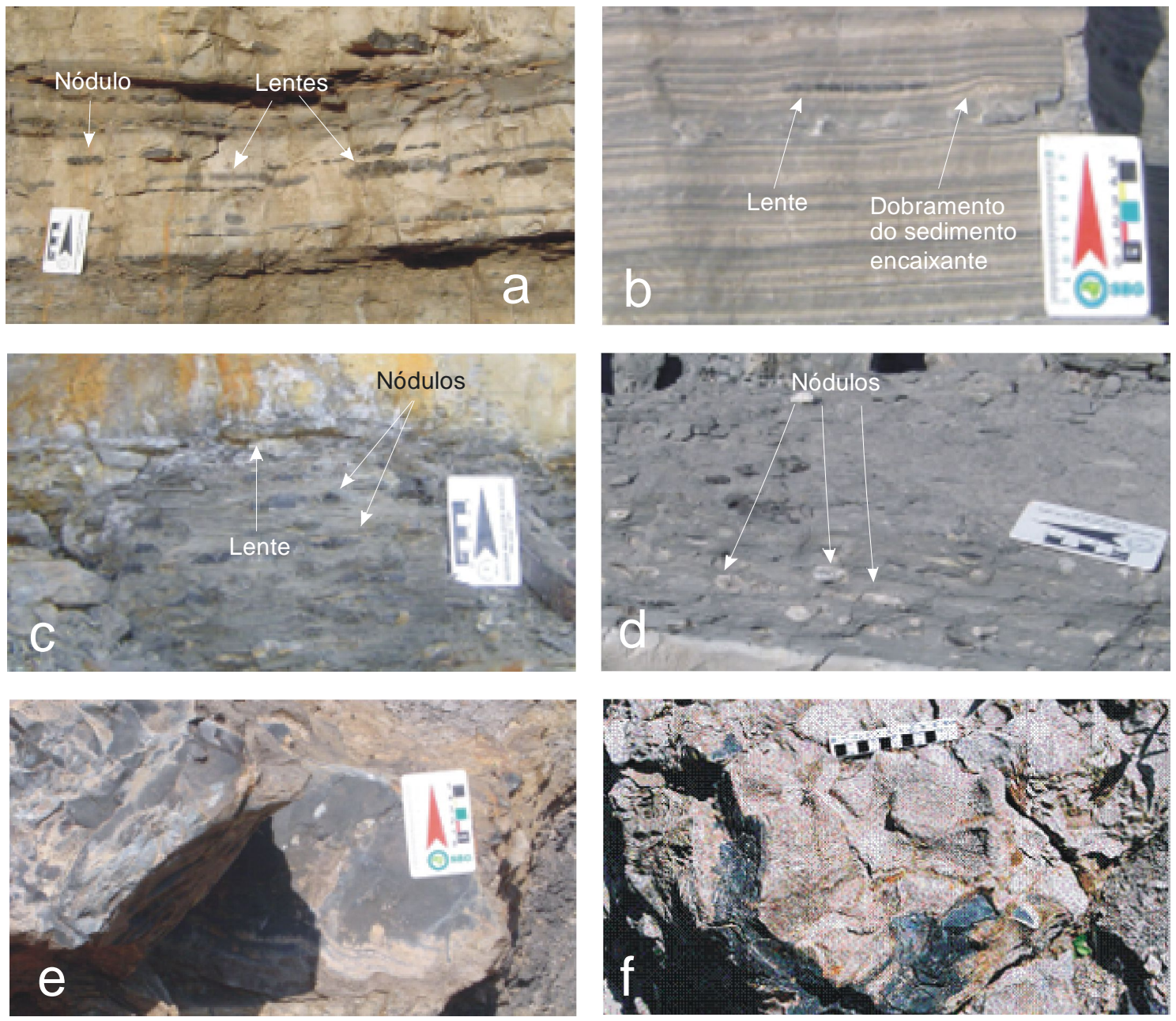

Figura 7: Diferentes tipos de sílex encontrados na Formação Assistência diagenético (a-b): carbonato com lentes e nódulos - Camada Bairrinho. (b): detalhe de dobramento de sedimento encaixante ao lado de lente. (c): folhelho com lentes e nódulos - Ritmitos Delgados. (d): nódulos em folhelho - Ritmitos Superiores. (e-f): sílex de substituição a carbonato - Camada de Dobras Enterolíticas.

\section{4 - PRINCÍPIOS DE ANÁLISE DE MICROBIOTAS EM SÍLEX}

\subsection{Introdução e breve histórico}

Estudar microorganismos orgânicos fossilizados em sílex, como cianobactérias e microalgas clorofíticas, é especialmente complexo devido, por um lado, à simplicidade morfológica inerente destes táxons, e outro, à variação morfológica decorrente de fatores ontogênicos, ecológicos e tafonômicos. Identificar microorganismos fósseis nas rochas, classificá-los e compreender o que as feições observadas revelam sobre o modo de vida e os processos bioestratinômicos e diagenéticos são procedimentos que, talvez bem mais que em outras áreas da paleontologia, esbarram no problema da metodologia taxonômica em estudos paleontológicos e na questão do próprio reconhecimento dos microfósseis. 


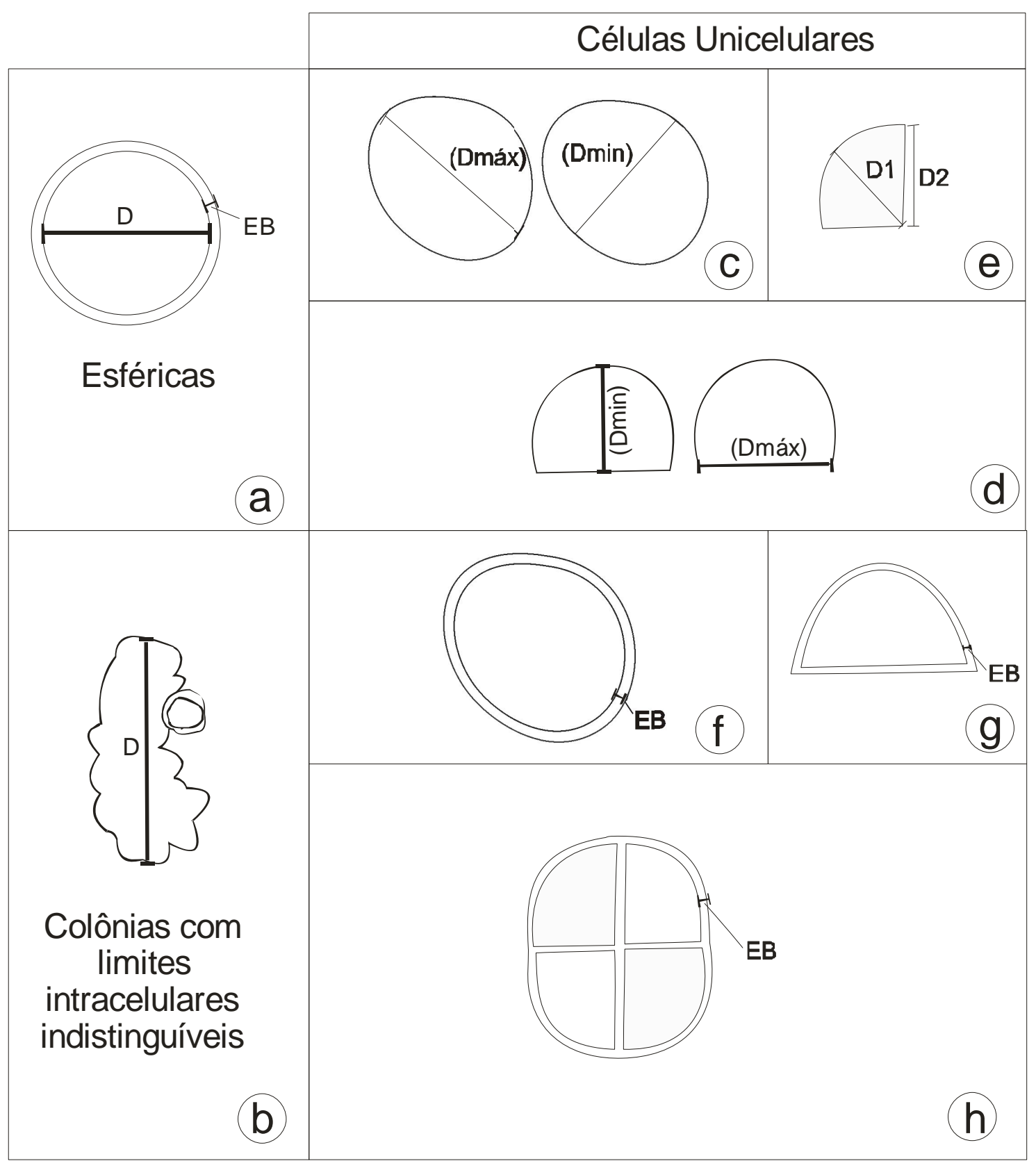

Figura 8: Parâmetros morfométricos: $\mathbf{D}=$ diâmetro; $\mathbf{E B}=$ espessura da bainha; $\mathbf{D m a ́ x}=$ diâmetro máximo; Dmin= diâmetro mínimo; D1 = diâmetro 1; D2 = diâmetro 2. (a): células esféricas. (b): colônia sem forma definida. (c): células subesférica. (d): células hemisferóides. (e): célula cuneiforme. (f-h): orientação das medidas da espessura das bainhas para cada forma celular.

Foram os estudos pioneiros com sílex microfossilífero do Pré-Cambriano de Barghoorn \& Tyler (1965) na Formação Gunflint e de Schopf (1968) e Schopf \& Blacic (1971) na Formação Bitter Springs que, alem de revelarem o potencial das lâminas delgadas de sílex negro no estudo de microbiotas fósseis, estabeleceram os 
procedimentos metodológicos básicos e critérios para identificação, classificação e interpretação destes microorganismos. Os trabalhos posteriores, como os de Hofmann (1976), Barghoorn et al. (1977) e Knoll \& Golubić (1979) refinaram a forma de se interpretar a variedade morfológica em microbiotas fósseis, levando em consideração os artefatos tafonômicos e variações ontogênicas invariavelmente presentes nestas assembléias. A influência de efeitos post-mortem na variedade morfológica de assembléias de microorganismos fósseis foi corroborada em experimentos atualísticos, como os de Francis et al. (1978) e Bartley (1996), entre outros.

\subsection{Avaliação do contexto sedimentar/diagenético das microestruturas}

O primeiro passo na confirmação de possíveis microorganismos fósseis em lâminas delgadas é a verificação da compatibilidade do contexto geológico da rocha com a presença de uma microbiota fóssil. Para tanto, a rocha deve ser (i) sedimentar ou sedimentar com baixo grau de metamorfismo (metassedimentar), (ii) ter sido depositada em ambiente de sedimentação favorável ao desenvolvimento e preservação de microorganismos autóctones (elementos bentônicos in situ) ou parautóctones (elementos planctônicos decantados no local) e (iii) apresentar história diagenética compatível com o grau de preservação dos supostos microorganismos orgânicos.

A variedade de fósseis mais resistentes à degradação físico-química (p.ex. palinomorfos, restos vegetais, carapaças de invertebrados e ossos) conta a favor da existência de uma microbiota fóssil. Isso porque se organismos tão delicados como microorganismos orgânicos forem preservados, devem ser encontrados juntamente com fósseis mais resistentes a degradação (Schopf 2001). A presença de abundante matéria orgânica insolúvel (querogênio) sugere condições de alta produtividade e grande acumulação de biomassa durante a época de sedimentação, oriunda principalmente de microorganismos fotossintetizantes.

Para se determinar se os supostos microorganismos fósseis são sindeposicional ou se depositaram posteriormente, é importante analisar a textura, estrutura, petrotrama da rocha, alem dos efeitos de processos diagenéticos como compactação, fraturamento e silicificação. Microorganismos casmolíticos, por exemplo, podem invadir fraturas e poros (Cloud \& Morrison 1979; Horodyski et al 1975). Já microorganismos endolíticos, dominados pelos gêneros Chroococcidiopsis e Gloeocapsa, são capazes de penetrar em rochas por dissolução a partir da superfície (Komárek 2003; Bhatnagar \& Bhatnagar 2005). 
Microorganismos orgânicos são facilmente degradados em ambientes sedimentares arenosos, agitados e oxidantes. Portanto, raramente se fossilizam em arenitos terrígenos (ver Simonetti \& Fairchild 2000). Por outro lado, rochas formadas em ambientes mais calmos, de circulação restrita e com altas taxas de litificação e/ou precipitação, como carbonáticos ou evaporíticos, quando substituídas precocemente por sílica diagenética, têm maiores chances de conservar microorganismos mais delicados.

\subsection{Reconhecimento de microorganismos fossilizados}

Para reconhecer microorganismos fósseis entre os demais objetos nas rochas, é importante distinguir, primeiramente, se os supostos microorganismos fósseis tenham composição orgânica. Isto é possível verificando-se as características ópticas e físicas dos invólucros (parede celular ou bainha extracelular), que variam de acordo com o grau de conservação da matéria orgânica. Por exemplo, cores desde amarelo claro até negro, texturas lisas a granuladas, evidências de flexibilidade (p.ex., dobras) ou/e de rasgos nas paredes, relevo óptico baixo e ausência de birrefringência são características típicas de microestruturas orgânicas (Subacius \& Amaral 1983; Gaucher et al. 1996; Versteegh \& Blokker 2004).

Concomitantemente, deve-se comparar a variedade morfológica apresentada pelos possíveis microorganismos fósseis com aquela de táxons atuais semelhantes (Hofmann 1976; Schopf 1992 a; Schopf 1992 b) e de microbiotas fósseis já conhecidas (Knoll \& Golubić 1979; Schopf 1995; Knoll 1996). Modificações morfológicas postmortem podem ser inferidas pela comparação com organismos modernos degradados (Horodyski et al. 1977; Francis et al. 1978; Bartley 1996) e com análises tafonômicas já realizadas em outras assembléias de microorganismos fósseis preservados em sílex (Hofmann 1976; Barghoorn et al. 1977; Oehler 1977; Knoll \& Golubić 1979).

\subsection{Avaliação da variedade morfológica e suas conseqüências na análise paleobiológica}

Diversos fatores influenciam a variedade morfológica de microbiotas modernas. Em uma população microbiana de uma única espécie, é comum se encontrar considerável variação de forma e tamanho, decorrentes principalmente do crescimento celular, do padrão e freqüência de divisão celular e do estágio de crescimento vegetativo. Populações microbianas atuais quase sempre possuem indivíduos de diversos tamanhos. $\mathrm{O}$ meio-ambiente pode ainda influenciar a variabilidade de formas, 
pois muitos microorganismos apresentam adaptações morfológicas (ecofenotipos) a condições físico-químicas diferentes (ver Nübel et al. 1999).

Todas estas variáveis também podem estar presentes em assembléias de microorganismos fósseis. Alem disso, os espécimes fósseis não conservam suas características bioquímicas nem suas estruturas intracelulares originais. Alem disso, muitas vezes apresentam alterações decorrentes da degradação física, química e microbiana. Conseqüentemente, a metodologia taxonomica que pode ser aplicada a estes microfósseis tem de se contentar com a análise de algumas poucas características morfológicas, como o tamanho, a forma e natureza do invólucro (parede celular e/ou bainha mucilaginosa) e padrões de divisão celular e/ou de agregação colonial.

A maneira de enfrentar o problema taxonômico de assembléias de microorganismos fósseis em sílex evoluiu desde os trabalhos pioneiros de Barghoorn e Tyler (1965), Schopf (1968) e Schopf e Blacic (1971). Schopf (1968) e Schopf \& Blacic (1971), por exemplo, descreviam um táxon a cada tipo morfológico (morfotipo) identificado. Embora a grande semelhança entre alguns fósseis e determinadas espécies modernas não deixe dúvidas quanto ao analogismo (Schopf 2001), trabalhos posteriores demonstraram que a diversidade morfológica aparentemente alta de muitas assembléias fósseis pode ser um artefato de preservação produzido pela degradação física, química e microbiana da microbiota original, bem como efeito da variedade morfológica devido às diferentes fases ontogênicas (p.ex.Hofmann 1976, Barghoorn et al.1977 e Knoll \& Golubić 1979).

A crítica a estas abordagens permite definir a hierarquia de importância dos critérios na elaboração da taxonomia. Assim, é possível adotar o tipo de invólucro (bainha e/ou parede celular) e o tamanho celular como um dos principais caracteres que identificam diferentes microorganismos unicelulares. Táxons muito parecidos podem ser diferenciados estatisticamente por parâmetros morfométricos (Imbrie 1959; Zhang 1985; Sergeev et al. 1995).

Por outro lado, a gama de diferentes morfologias observada na assembléia pode ser útil na reconstituição do padrão de divisão celular ou mesmo do padrão reprodutivo dos microorganismos fósseis, principalmente se as variantes morfológicas, o tamanho e características dos invólucros forem parecidos aos de um táxon atual (p.ex. Knoll \& Golubić 1979; Zang 1988; Taylor et al. 1997). A presença de todas as variantes morfológicas na mesma agregação de microfósseis, ou na mesma lâmina delgada ou restrita ao mesmo nível estratigráfico reforça o argumento a favor de uma relação ontogenética entre os espécimes. 
Por outro lado, as características de material orgânico intracelular (como opacidade) e coloração do invólucro têm menor valor na diferenciação taxonômica, pois representam mais as conseqüências de processos tafonômicos do que os vestígios de feições orgânicas originais (ver Hofmann 1976; Oehler et al. 1976; Golubić \& Barghoorn 1977; Barghoorn et al. 1977; Francis et al. 1978; Knoll \& Golubić 1979, Bartley 1996; Taylor et al. 1997).

Para se reconstituir os processos tafonômicos, é importante comparar as morfologias encontradas com a de microorganismos atuais degradados artificialmente em modelos atualísticos (p.ex. Oehler 1977; Francis et al. 1978; Bartley 1996) e com interpretações de processos tafonômicos de outras microbiotas fósseis (Hofmann 1976, Golubić \& Barghoorn 1977, Barghoorn et al. 1977).

Por fim, a distinção entre microorganismos fósseis planctônicos e bentônicos nem sempre é simples. Para tal, é importante analisar o contexto paleoambiental geral (Butterfield \& Chandler 1992; Knoll et al. 1989, 1991). Em rochas compostas de esteiras microbianas ou estromatólitos, é de se esperar, como hipótese de trabalho inicial, que os microfósseis mais abundantes representem os microorganismos bentônicos autóctones que construíram as esteiras. Da mesma forma, microfósseis encontrados em litologias devido a decantação ou acumulação mecânica serão interpretados, inicialmente, como elementos parautóctones, em grande parte planctônicos. Knoll et al. (1989, 1991) discutem critérios para distinguir entre construtores de esteiras, habitantes casuais de esteiras e elementos planctônicos preservados em microbiotas silicificadas do Neoproterozóico de Svalbard. Espécimes cocóides, não coloniais ou coloniais com poucas células, quando encontrados em esteiras e em pouco número, espalhados e de forma descontínua devem representar elementos planctônicos; já os espécimes encontrados em número tão grande que formam parte significativa da esteira devem ter sido responsáveis pela formação da esteira, sendo assim elementos bentônicos. Já os habitantes casuais são aqueles microorganismos que formam pequenos agregados dentro das esteiras, podendo até ter construído parte dela. Estes microfósseis representam, em sua maioria, microoganismos bentônicos, mas poderão incluir, excepcionalmente, alguns elementos planctônicos que continuaram a crescer, brevemente, após decantação. 


\section{6 - Cuidados na interpretação de microorganismos fósseis transparentes em três dimensões}

A interpretação da morfologia tridimensional de colônias celulares necessita cuidados especiais. Por exemplo, a orientação dos arranjos coloniais em relação ao observador raramente é ideal, fazendo com que formatos diferentes se pareçam iguais ou muito semelhantes. Oehler et al. (1976) mostraram que arranjos planares de quatro células, quando vistos lateralmente, podem ser interpretados como apenas duas células, ou ainda, que arranjos de quartetos romboidais podem parecer tetraédricos. A Figura ilustra uma situação comum na Formação Assistência, onde duplas de células hemisferóides parecem tratar-se de apenas uma célula, e colônias com quatro células cuneiformes tornam-se idênticas a conjuntos com duas células hemisferóides. Com efeito, estes vieses podem ser amenizados através de análises morfométricas e cuidados especiais no exame microscópico.

O fato dos microorganismos fósseis serem translúcidos a transparentes, por sua vez, também pode dificultar o reconhecimento ou mesmo detecção de espécimes. Este problema pode ser mitigado, pelo menos parcialmente, pelo exame microscópico em diferentes níveis ópticos, o que permite observar detalhes morfológicos das colônias e células em diferentes escalas.
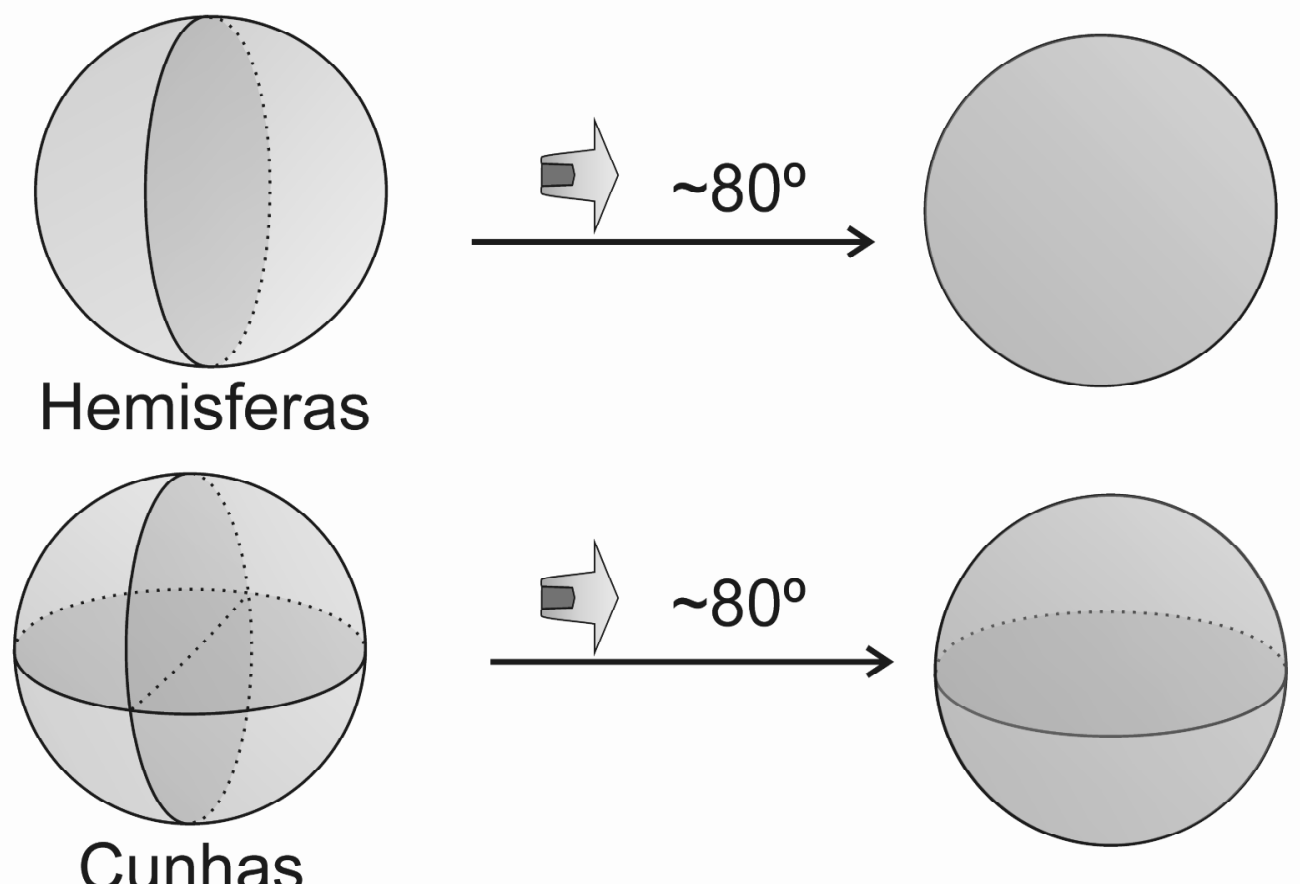

Figura 9: Possíveis vieses ópticos na observação de conjuntos de microorganismos fósseis. À direita, espécimes em orientações não ideais. Observa-se que formas hemisféricas podem parecer esféricas, e células cuneiformes podem se mostrar hemisféricas. 


\section{6 - Distinção entre fósseis de cianobactérias e clorófitas microscópicas unicelulares}

Devido à simplicidade e às semelhanças morfológicas entre clorófitas unicelulares e cianobacterias fósseis, a diferenciação entre estes dois grupos nem sempre é imediata. Para tanto é necessário avaliar a história evolutiva, as características morfológicas e feições tafonômicas dos dois grupos. Por exemplo, é mais seguro admitir que um microorganismo fóssil seja eucarionte em sucessões fanerozóicas do que em níveis Pré-Cambrianos, pois no Fanerozóico a vida eucariótica domina o registro fóssil.

A avaliação das dimensões celulares é um critério que tem sido muito utilizado nesta diferenciação. Geralmente, microfósseis orgânicos preservados por permineralização precoce por sílica conservam tamanhos semelhantes aos originais. Suspeita-se, porem, que quando a silicificação ocorreu, a maioria dos microrganismos já estava morta ou, no mínimo, moribunda e em variados estados de degradação. Processos como dessecação, desintegração física, digestão microbiana, colapso e coalescência mudam o aspecto orginal das células (Hofmann 1976, Oehler et al. 1976, Golubić \& Barghoorn 1977, Barghoorn et al. 1977, Knoll \& Golubić 1979, Bartley 1996). Por isso, a utilização do critério tamanho, com base na comparação com microorganismos modernos, deve ser restrita a microfósseis bem preservados, sem deformação post-mortem aparente.

A maioria das cianobactérias unicelulares atuais exibem diâmetros entre 1 e 20 $\mu \mathrm{m}$ (Schopf 1992b; Komárek 2003), enquanto as clorófitas unicelulares geralmente são maiores que $30 \mu \mathrm{m}$ (Schopf 1992b; Shubert 2003). Schopf \& Oehler (1976), Barghoorn \& Knoll (1975), Fairchild (1985) e Schopf (1992b) analisaram a utilização de tamanho como critério de distinção entre eucariontes e procariontes fossilizados, e concordando que na aplicação de tamanho como critério único, somente microorganismos fósseis com diâmetros celulares maiores que 55 m podem ser considerados eucariontes com segurança, uma vez que este é o diâmetro máximo de células esferóides entre procariontes atuais comuns. Schopf (1992b) argumenta ainda que a faixa de diâmetro celular que confere segurança na identificação de cianobactérias é de 2,5 $\mu \mathrm{m}$ a $10 \mu \mathrm{m}$, enquanto os microfósseis maiores que $25 \mu \mathrm{m}$ não coloniais são mais provavelmente eucariontes.

Feições tafonômicas também podem contribuir nesta analise, embora não de uma forma necessariamente conclusiva. Segundo Knoll \& Golubić (1979), células 
esferóides de clorófitas, quando degradadas, têm morfologias elipsóides, enquanto células de cianobactérias tendem a murchar e apresentar dobras e cristas superficiais.

Tabela 3: Distribuição qualitativa dos microfósseis ao longo da Formação Assistência. Onde $+=$ Raro; $++=$ pouco; $+++=$ muito; ++++ incontáveis.

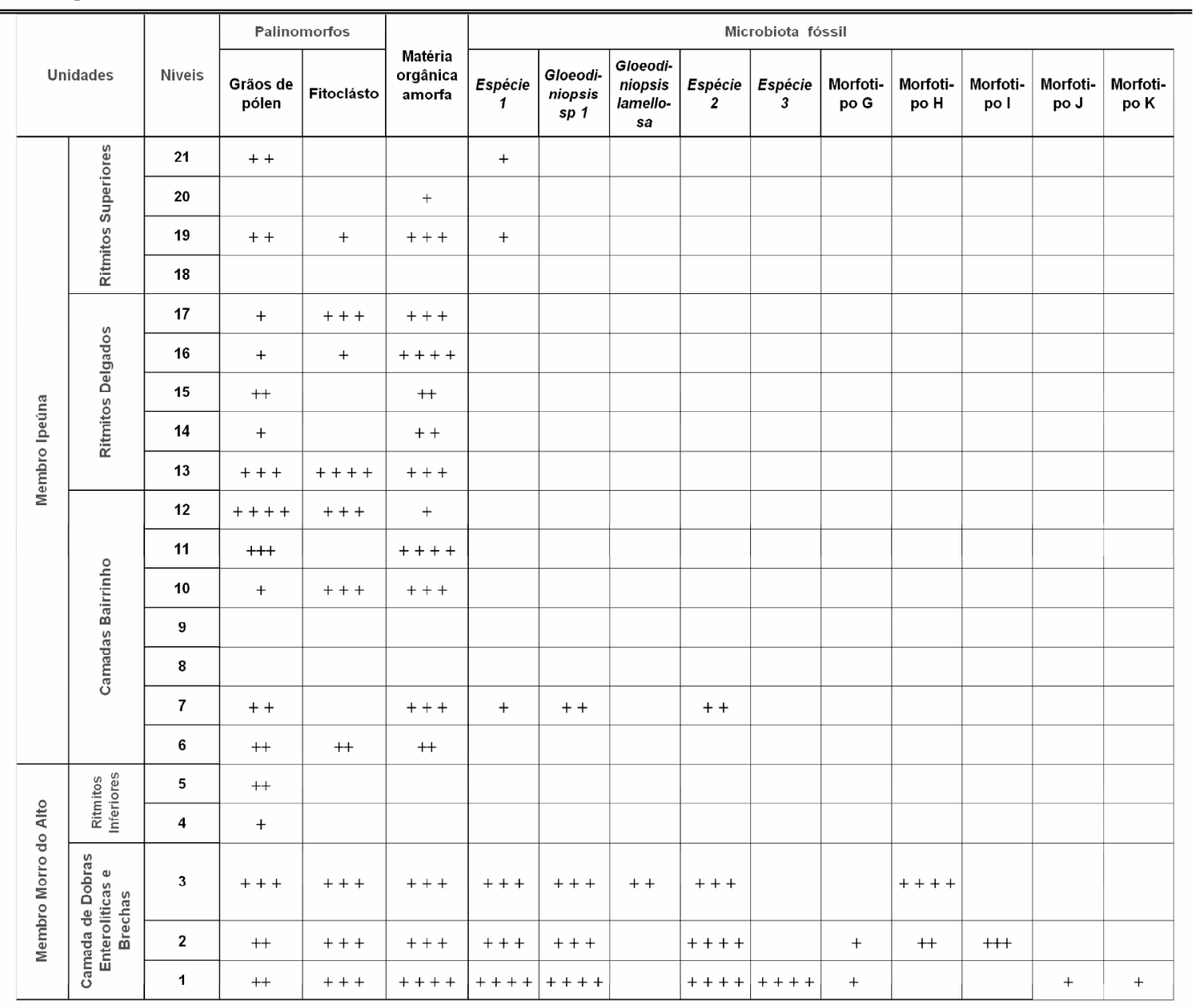

\section{5 - CARACTERÍSTICAS GERAIS DOS MICROFÓSSEIS ENCONTRADOS}

A microbiota da Formação Assistência foi observada em lâminas das localidades Paraisolândia 1, Fartura A, Soldeira Estrada e Estrela, tendo por isso distribuição geográfica relativamente ampla (Figura 2). Em todas as localidades observaram-se palinomorfos e matéria orgânica amorfa. Estratigraficamente, está concentrada na Camada de Dobras Enterolíticas, na base do membro Morro do Alto, ao passo que palinomorfos e matéria orgânica amorfa foram observadas em quantidade relativamente homogênea ao longo de toda a formação (Tabela 3). 
A aplicação dos critérios e princípios discutidos no seção anterior permitiu reconhecer onze táxons de microorganismos fósseis na Formação Assistência. Os componentes desta assembléia foram classificados da seguinte maneira:

- Cinco táxons com afinidades biológicas precisas, denominados: Espécie 1 (Morfotipos A, B e C), Gloeodiniopsis sp. 1, Gloeodiniopsis aff. G. lamellosa, Espécie 2 e Espécie 3 (Morfotipos D, E e F) (Figuras 10 - 14 d).

- Cinco táxons incertae sedis, ou seja, com afinidades biológicas incertas, aqui designados Morfotipos G a K. (Figuras 14 e-o).

- Alguns dúbiomicrofósseis, que são microestruturas que não se pôde determinar se são de origem biológica (15 a-d).

Em grande parte das lâminas os microorganismos fósseis ocorrem em quantidade tão elevada constituem o principal componente da rocha. Todos são unicelulares, mesmo assim, a variedade morfológica encontrada foi surpreendentemente alta. Há células solitárias (Figura 13) e coloniais (Figura 10 m). Em muitos dos microfósseis, distinguem-se claramente uma bainha externa e, mais internamente, vestígios da parede celular (Figura 13 d-e), enquanto outros são limitados por um único invólucro orgânico, cuja natureza da estrutura original (bainha ou parede celular) nem sempre é clara (Figura 12). Há bainhas individuais (Figura 13 a-e), ou coloniais, que formam envelopes (Figura 14 a-d). Foram encontradas bainhas espessas (Figura 14 c), finas (Figuras 12 ko), difusas (Figura 11 a) e com limites bem definidos (Figura 13 d-e). Os espécimes encontrados têm entre 5 e $55 \mu \mathrm{m}$ de diâmetro, contudo a maioria está entre 10 e $30 \mu \mathrm{m}$ (Tabela 4). A coloração é bastante variada (Figuras 10 e 14 d). Há células esféricas (Figura 13 a-f), subesféricas (Figura 11 a-d), hemisferóides (Figura 11 k-n), cuneiformes (Figuras 12 j) e romboidais (Figura 14), sendo a maioria subesférica ou hemisferóide. Foram encontradas células densamente agregadas (Figura $10 \mathrm{~m}$ ), em arranjos aleatórios (Figura 14 1-m), pouco definidos (Figura 10 a-f), ou ainda em duplas ou trios (Figura 14 b), quartetos (Figura 11 n-o). Há conjuntos planares (Figura 14 c-d), cubóides (Figura 11 1), framboidais (Figura 14 n-o), em pacotes (Figura 12) ou em arranjos mistos (Figura $10 \mathrm{~m}$ ). Resíduos intracelulares variam de translúcidos (Figura 11 l) a opacos (Figura 13 b), com aspecto amorfo (Figura 10 l), granular (Figura 14 m), concentrados centralmente (Figura 12 g) ou próxima à superfície (Figura 13a, e).

Muitos dos táxons são parecidos entre si. Espécie 1, Gloeodiniopsis sp 1 e Espécie 2 são todos abundantes e constituídos por células subesféricas, hemisferóides e cuneiformes. Alem disso, as células hemisferóides de Gloeodiniopsis aff. G. lamellosa são bastante similares às células hemisferóides destes três táxons (Figuras 10 k-o, 12, 14 
a-d). A variante Morfotipo C da Espécie 1 se diferencia destes táxons por apresentar uma bainha fina, com limites bem nítidos (Figura 10 k-o). Somente Gloeodiniopsis aff. G. lamellosa apresenta bainha espessa bastante nítida e arranjo planar (Figura 14 c-d). Já a diferenciação de Gloeodiniopsis sp 1 da Espécie 2 é mais difícil, pois os dois ocorrem em abundância, muitas vezes na mesma lâmina, e nenhum deles tem bainha nítida. Suas diferenças são muito discretas. Por exemplo, Gloeodiniopsis sp 1 tem parede mais lisa e opaca em comparação com a Espécie 2. Na Seção 6.2 este problema será discutido em maior profundidade.

Dos cinco morfotipos incertae sedis, somente dois (Morfotipo I e Morfotipo J) foram encontrados em grande quantidade, porém apresentam morfologias que impossibilitam a elaboração de uma taxonomia mais precisa. Os demais táxons são considerados incertae sedis devido ao pequeno número de espécimes encontrados (Figura 14 e-o).

Entre os dubiomicrofósseis, observaram-se, por exemplo, microestruturas esferóides e opacas, que podem ser possíveis resíduos intracelulares de organismos unicelulares, ou matéria orgânica que fortuitamente assumiu esta morfologia (Figura 15 a-b). Destaca-se também objetos subesféricos, transparentes e com superfície rugosa, aleatoriamente arranjados, alguns em massas botrioidais (Figura $15 \mathrm{c}-\mathrm{d}$ ), que podem ser pequenos grãos de carbonatos recobertos por matéria orgânica amorfa ou variantes do ciclo de vida do Morfotipo L (Figura 14 n-o).

Palinomorfos e matéria orgânica amorfa foram observados tanto no sílex quanto nos carbonatos, porem em maior abundância no sílex. Em uma lâmina encontrou-se carapaças incarbonizadas de artrópodes em sedimento carbonático. Os palinomorfos incluem fitoclástos e grãos de pólen de gimnosperma. Alguns destes grãos identificados como dos gêneros Limitisporites ou Alisporites (Figura 15 i) Lueckisporites (Figura 15 1) e Staurosaccites (Figura $15 \mathrm{~m}$ ). 


\begin{tabular}{|c|c|c|c|c|c|c|c|c|}
\hline & Táxons & Localidade & Morfologia medida & $\begin{array}{c}\text { Dmáx ou } \\
\text { D médio } \\
(\mathrm{mm})\end{array}$ & $\mathbf{N}$ & $\begin{array}{c}\text { EB } \\
\text { médio } \\
(\mathrm{mm})\end{array}$ & $\mathbf{N}$ & $\begin{array}{c}\text { Arranjo } \\
\text { celular }\end{array}$ \\
\hline \multirow{5}{*}{ 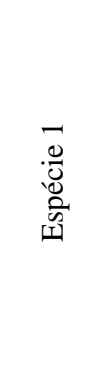 } & Morfotipo A & $\begin{array}{c}\text { Paraisolândia } \\
1\end{array}$ & Colônia & 50,3 & 37 & & & Irregular \\
\hline & Morfotipo B & $\begin{array}{c}\text { Paraisolândia } \\
\text { 1, Cruzeiro }\end{array}$ & Células subesféricas & 18,6 & 35 & & & Solitárias \\
\hline & \multirow{3}{*}{ Morfotipo C } & \multirow{3}{*}{$\begin{array}{c}\text { Paraisolândia } \\
1\end{array}$} & Células subesféricas & 13,6 & 66 & \multirow{3}{*}{1,3} & \multirow{3}{*}{71} & \multirow{3}{*}{$\begin{array}{l}\text { Solitárias, } \\
\text { duplas, trios } \\
\text { e quartetos }\end{array}$} \\
\hline & & & Células hemisferóides & 15 & 232 & & & \\
\hline & & & Células cuneiformes & 15,8 & 71 & & & \\
\hline \multirow{3}{*}{\multicolumn{2}{|c|}{ Gloeodiniopsis sp1 }} & \multirow{3}{*}{$\begin{array}{c}\text { Paraisolândia } \\
\text { 1, Estrela, } \\
\text { Assistência }\end{array}$} & Células subesféricas & 22,8 & 78 & & & \multirow{3}{*}{$\begin{array}{l}\text { Solitárias, } \\
\text { duplas, trios } \\
\text { e quartetos }\end{array}$} \\
\hline & & & Células hemisferóides & 17,8 & 58 & & & \\
\hline & & & Células cuneiformes & 14,4 & 17 & & & \\
\hline \multirow{3}{*}{\multicolumn{2}{|c|}{ Espécie 2}} & \multirow{3}{*}{$\begin{array}{c}\text { Paraisolândia } \\
\text { 1, Estrela }\end{array}$} & Células subesféricas & 14,9 & 27 & & & \multirow{3}{*}{$\begin{array}{l}\text { Duplas, trios } \\
\text { e quartetos. }\end{array}$} \\
\hline & & & Células hemisferóides & 15,1 & 62 & & & \\
\hline & & & Células cuneiformes & 14,7 & 135 & & & \\
\hline \multirow{3}{*}{ 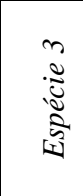 } & Morfotipo D & $\begin{array}{l}\text { Paraisolândia } \\
\text { 1, Estrela }\end{array}$ & Células esféricas & 31,1 & 45 & 2,1 & 28 & Solitárias \\
\hline & & $\begin{array}{c}\text { Paraisolândia } \\
1 \\
\end{array}$ & Células esféricas & 24 & 8 & 2,2 & 1 & $\begin{array}{l}\text { Solitárias ou } \\
\text { em conjuntos }\end{array}$ \\
\hline & Morfotipo F & Estrela & Células esféricas & 50,3 & 2 & & & Solitárias \\
\hline \multicolumn{2}{|c|}{ Gloeodiniopsis lamellosa } & $\begin{array}{c}\text { Paraisolândia } \\
\text { 1, Estrela }\end{array}$ & Células hemisferóides & 12,9 & 6 & & & $\begin{array}{c}\text { Duplas ou } \\
\text { conjuntos } \\
\text { planares com } \\
\text { células em } \\
\text { múltiplos de } \\
2 \\
\end{array}$ \\
\hline \multicolumn{2}{|r|}{ Morfotipo G } & $\begin{array}{c}\text { Paraisolândia } \\
\text { 1, Estrela, } \\
\text { Assistência }\end{array}$ & Células esféricas & 15,1 & 7 & & & $\begin{array}{l}\text { Fileiras de } \\
\text { células } \\
\text { esféricas }\end{array}$ \\
\hline \multicolumn{2}{|r|}{ Morfotipo H } & $\begin{array}{l}\text { Assistência, } \\
\text { Estrela }\end{array}$ & Colônia & 55 & 6 & & & $\begin{array}{l}\text { Fileiras de } \\
\text { células } \\
\text { esféricas }\end{array}$ \\
\hline \multicolumn{2}{|r|}{ Morfotipo I } & Estrela & Colônia & 71,8 & 34 & & & Irregular \\
\hline \multicolumn{2}{|r|}{ Morfotipo J } & $\begin{array}{c}\text { Paraisolândia } \\
1\end{array}$ & & & & & & Irregular \\
\hline \multicolumn{2}{|r|}{ Morfotipo K } & $\begin{array}{c}\text { Paraisolândia } \\
1\end{array}$ & Colônia & 35 & 1 & & & "Frambóide" \\
\hline
\end{tabular}



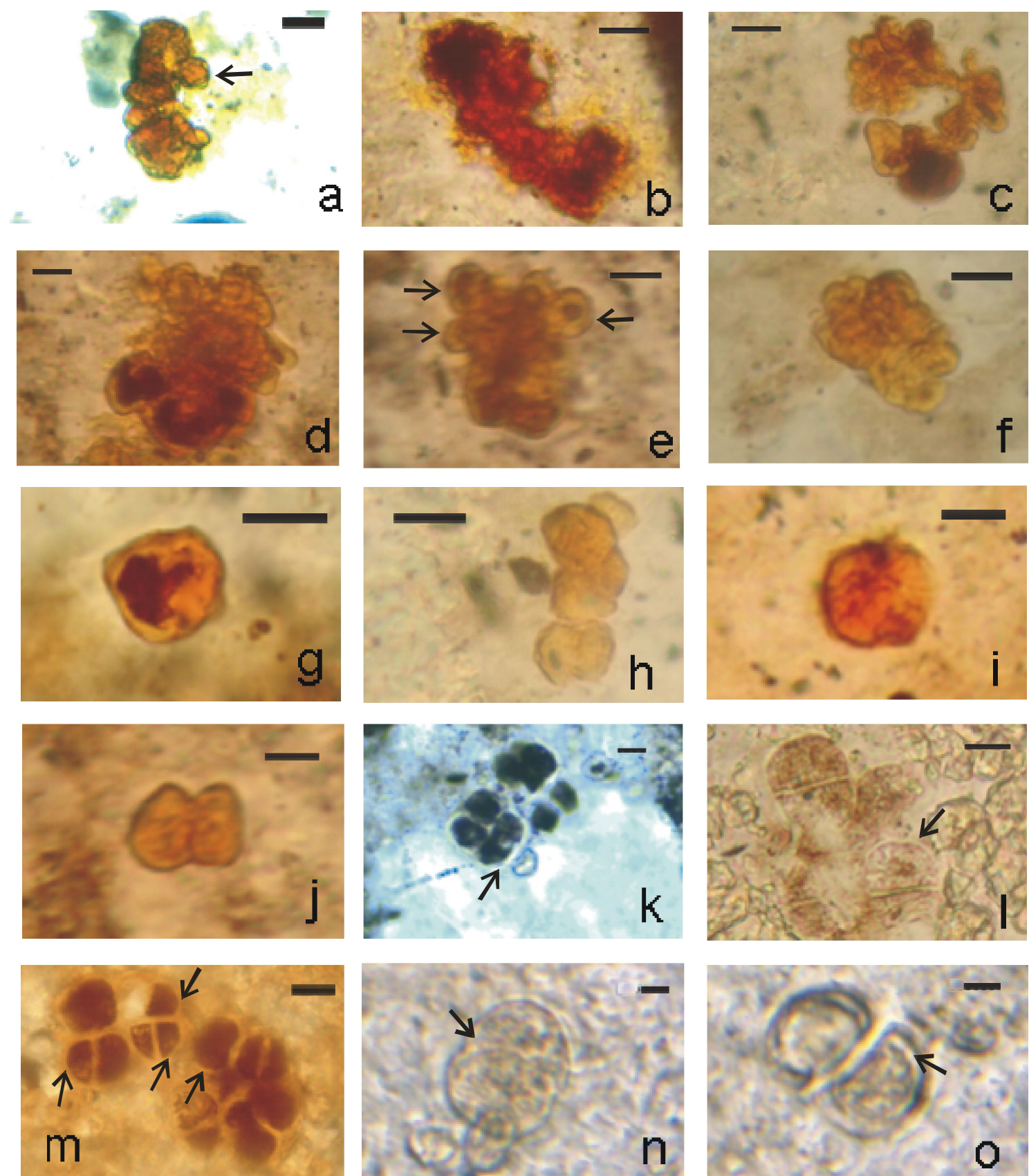

Figura 10: Espécie 1. (a-f): Morfotipo A: colônias com limites celulares indistinguíveis. Setas apontam estruturas esferóides presentes nas extremidades de alguns espécimes. (a,e-f): lâmina GP/L-G6 2; (b): lâmina PAR 14; (c): lâmina GP/L-G6 12 (d): lâmina GP/L-G6 2. (g-j): Morfotipo B: células esferóides, solitárias ou em colônias de poucos indivíduos. (g): lâmina GP/L-G6 4. (h): GP/L-G6 12; (i): lâmina GP/L-G6 2; (j): lâmina GP/L-G6 12. (k-o): Morfotipo C: setas indicam bainha colonial fina, com limites bem definidos. (k): colônias com resíduos intracelulares opacos e negros. (l-m): arranjos celulares com células subesféricas, hemisferóides e cuneiformes. (n): dupla de células subesféricas. (o): dupla de células hemisferóides. (k, n-o): lâmina GP/L-G6 2; (l): lâmina GP/L-G6 7; (m): lâmina GP/L-G6 6. Todas espécimes da localidade Paraisolândia 1. Barra $=10 \mu \mathrm{m}$. 

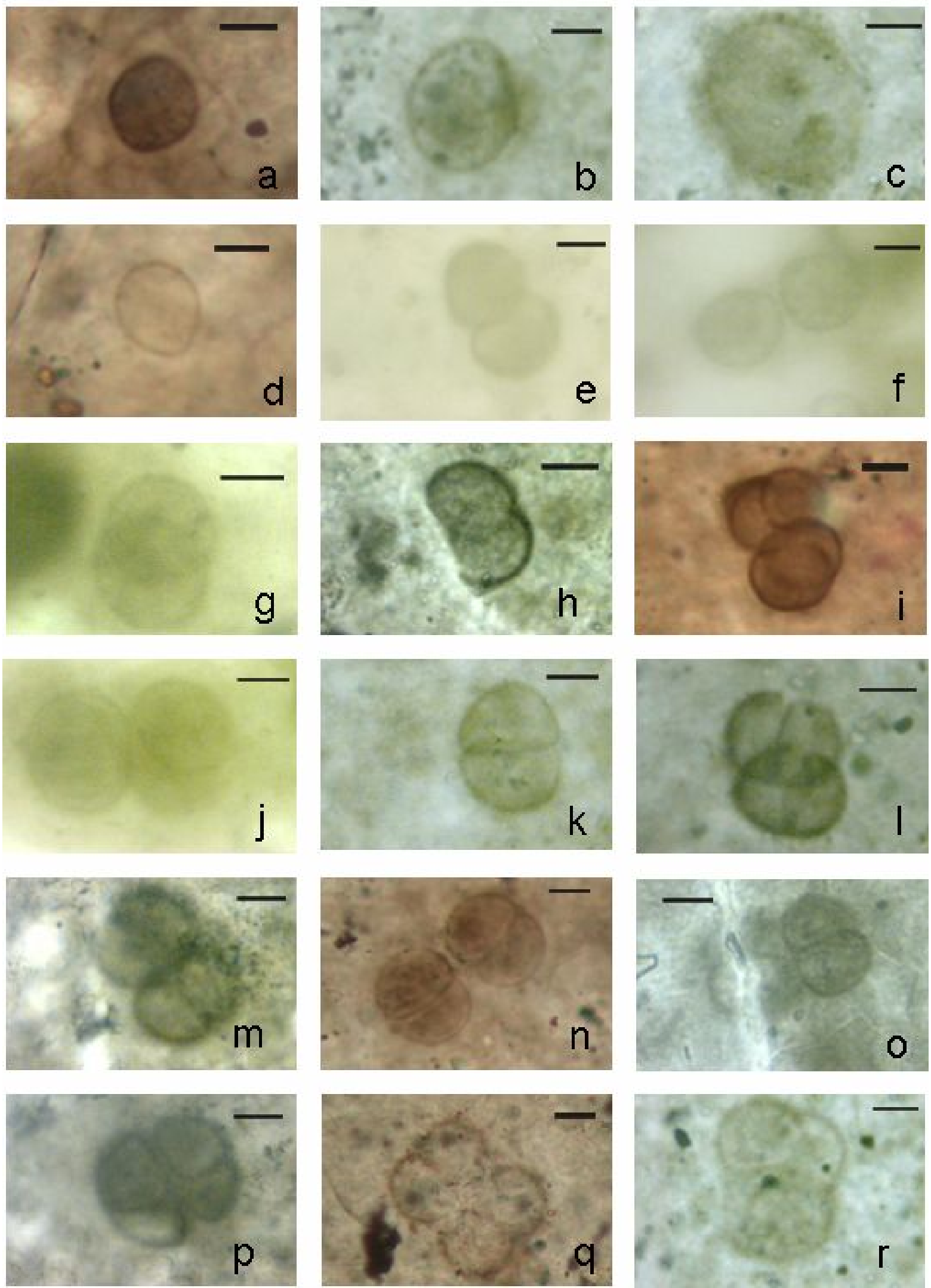

Figura 11: Gloeodiniopsis sp 1: células subesféricas, hemisferóides e cuneiformes, todas com parede espessa. (a-d): células subesféricas solitárias. (e-h): duplas de células subesféricas. (i-j): quartetos de células subesféricas. (k-o): células hemisferóides em arranjos de dois, quatro ou oito indivíduos. (p): Conjunto com quatro células cuneiformes. (q-r): quartetos, com arranjo aparentemente planar. Todos os espécimes encontram-se lâminas delgadas de amostras de sílex da localidade Estrela. (a): lâmina GP/L-G6 22 (b-d): lâmina GP/L-G6 21. Barra = $10 \mu \mathrm{m}$. 

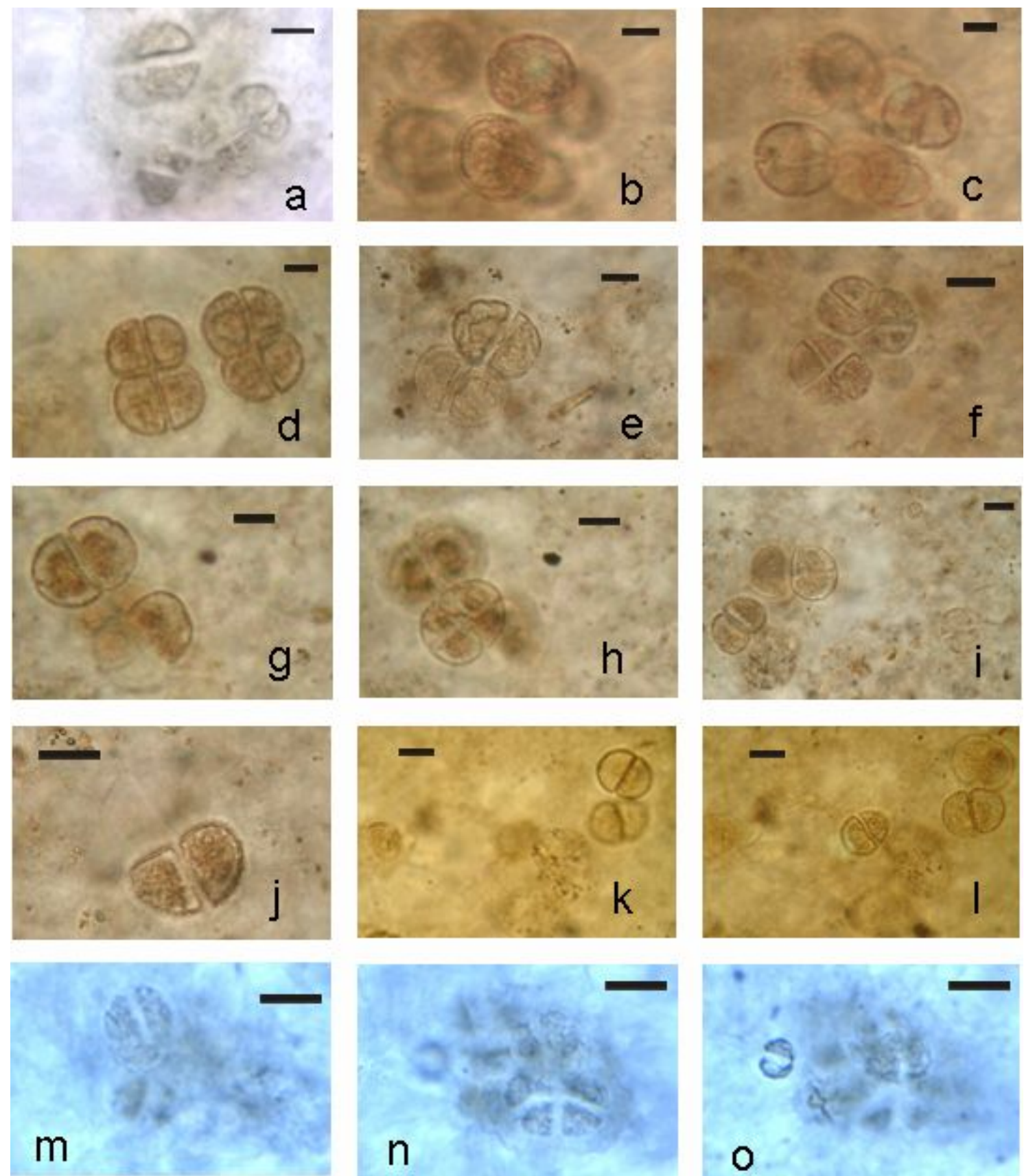

Figura 12: Espécie 2: células agregadas em pacotes. (b-c), (e-f), (g-h), (i-j), (k-l) e (m-o): conjuntos, em diferentes níveis ópticos, com células sobrepostas. No mesmo conjunto, há células com morfologia subesféricas, hemisferóides e cuneiformes. Os espécimes encontram-se lâminas delgadas de amostras de sílex da localidade Estrela e Paraisolândia. (a-d): lâmina GP/L-G6 3; (e-f), (i), (p-r): lâmina GP/L-G6 8; (g-h), (j-o): lâmina GP/L-G6 13. Barra $=10 \mu \mathrm{m}$. 

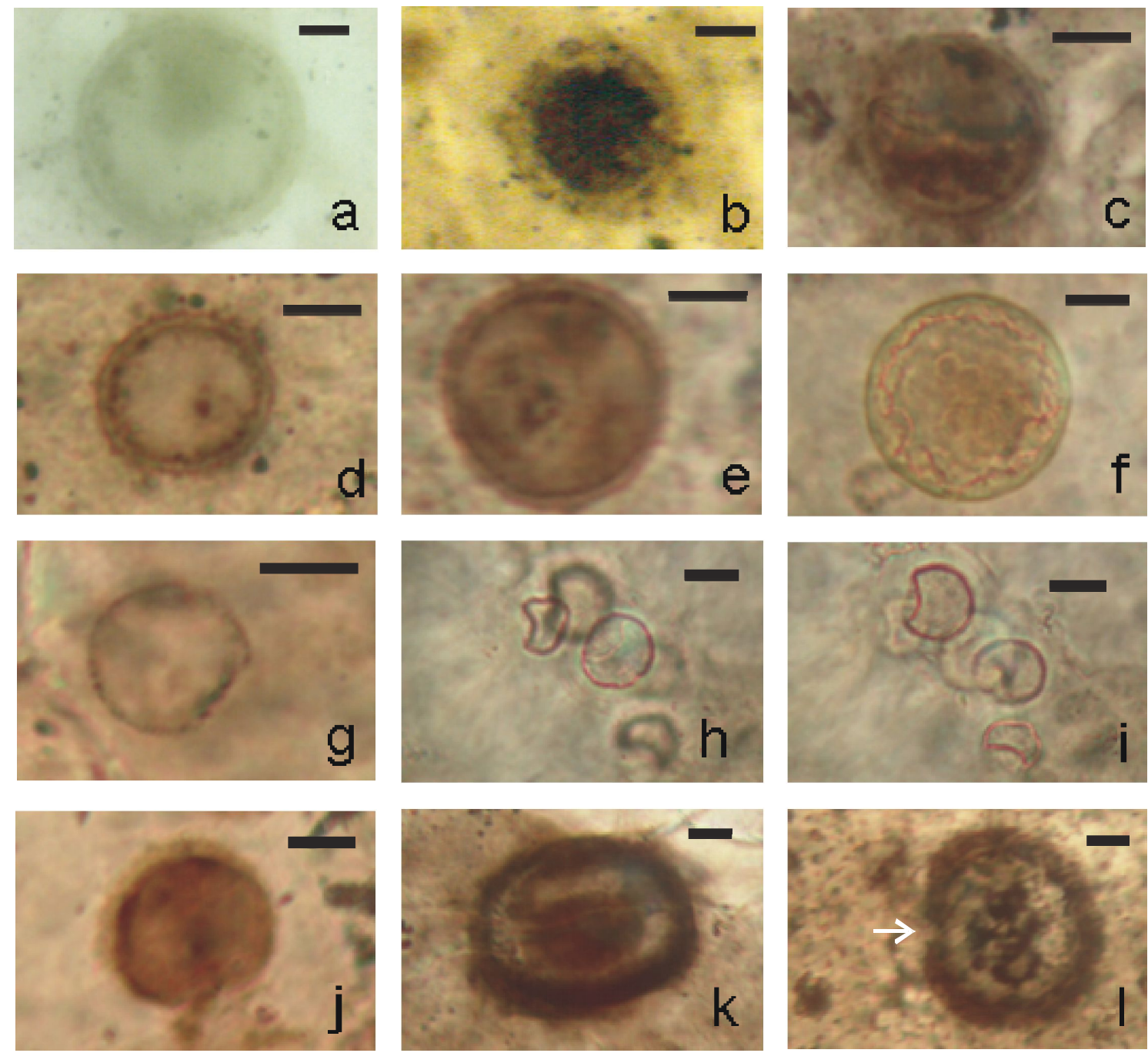

Figura 13: Espécie 3. (a-f): Morfotipo D, células solitárias, esféricas, com invólucro composto por uma bainha fina e conspícua entre finas camadas mais opacas. (f): espécime com parte interna do invólucro degradada. (g-j): Morfotipo E, células solitárias, esferóides, com uma região achatada. (k-l): Morfotipo F, células solitárias, subesféricas, com invólucro composto por uma espessa parede celular. (l): seta em região com abertura. Os espécimes encontram-se lâminas delgadas de amostras de sílex das localidades Estrela e Paraisolândia. (a-d): lâmina; GP/L-G6 21; (e, k, l): GP/L-G6 23; (f, h-j): lâmina GP/L-G6 8; (g): lâmina GP/L-G6 22. Barra $=10 \mu \mathrm{m}$.

\section{6 - PROBLEMAS DE INTERPRETAÇÃO PALEOBIOLÓGICA}

\section{1 - Espécie 1: Nem Gloeocapsomorpha prisca nem Botryococcus braunii}

Em estudos de microorganismos simples preservados tridimensionalmente em sílex, um dos principais problemas de interpretação paleobiológica é a comparação desses microfósseis com outros de morfologia parecida conhecidos principalmente de resíduos palinológicos, onde comumente ocorrem como compressões bidimensionais. Este problema é exemplificado na microbiota da Formação Assistência pela Espécie 1, que guarda certa 
semelhança com Gloeocapsomorpha prisca Zalessky, 1917 e Botryococcus braunii Kützing 1849.

Apesar das suas consideráveis diferenças morfológicas, Morfotipos A, B e C são considerados variantes de um mesmo táxon (Espécie 1) principalmente porque, na maioria das vezes, são encontrados juntos na mesma lâmina, e poucas vezes com outros microorganismos fósseis. Em nenhuma lâmina que continha espécimes do Morfotipo $\mathrm{C}$ se observou outro tipo de microorganismos que não fossem os Morfotipos A e B. Em uma das amostras da localidade Paraisolândia 1 havia um estromatólito colunar silicificado, que continha os três morfotipos, com grande abundância de Morfotipo C (Figura 16). Neste caso, Morfotipo $\mathrm{C}$ deve ter formado estas esteiras, o que prova que tem hábito bentônico.

Morfotipos A e B se destacam dentre os demais microorganismos fósseis da formação pela coloração marrom-alaranjada. Algumas hipóteses que explicam esta coloração, já sugeridas para microorganismos de outras unidades, incluem: (i) compressão de bainhas mucilaginosas extracelulares (Foster et al. 1989), (ii) recobrimento por matéria orgânica amorfa (Kremer 2006) e (iii) polimerização de envoltórios extracelulares a partir de restos orgânicos (Burns 1982; Golubić 2007, comunicado pessoal).

Restos orgânicos com este aspecto são reportados freqüentemente em estudos com preparações palinológicas, principalmente de folhelhos, inclusive no Subgrupo Irati, e classificados como B. braunii ou G. prisca (Burjack 1984; Silvia \& Cornford 1985; Faure \& Cole 1999).

G. prisca é uma espécie paleontológica, originalmente interpretada por Zalessky (1917 apud Foster et al. 1989a) como equivalente às espécies modernas de Gloeocapsa da família cianobacteriana Chroococcaceae. Posteriormente, o táxon foi reinterpretado como análogo morfológico das espécies atuais do gênero Entophysalis e transferido para a família Entophysalidaceae, também uma cianobactéria (Foster et al. 1989a).

Já $B$. braunii é um táxon atual que tem sido atribuído a microfósseis até do Paleozóico inferior. A espécie moderna é comum em águas doces, mas suporta salinidade baixa (Wake 1993; Berkaloff et al. 1984). Quando reportados no registro fóssil, espécimes classificados como B. braunii são comumente utilizados como indicadores paleoambientais de condições parecidas com as do microorganismo moderno (p.ex. Amenábar \& Ottone 2003, Derenne et al. 1992; Fowler et al. 2004).

Determinados biomarcadores, quando encontrados juntamente com microorganismos fósseis deste tipo, comumente são utilizados para justificar para esta classificação de $B$. braunii e G. prisca (p.ex. Derenne et al. 1992; Blokker et al. 2001; Fowler et al. 2004). 
Blokker et al. (2001) mencionaram que o material extracelular de B. braunii forma lipídios resorcinólicos em cadeias lineares, enquanto a matéria orgânica oriunda de G. prisca forma o polímero poli(n-alkyl resorcinol). Segundo Foster et al. (1989a), a distribuição de $n$ alkanos G. prisca é distinta das de B. braunii.

Já Derenne et al. 1992, Fowler et al. 2004 e Foster et al. (1989a) exploraram também as diferenças morfológicas entre as duas espécies. Segundo estes autores, a textura da superfície dos agregados celulares de $G$. prisca é lisa, enquanto a de B. braunii apresenta covas oriundas das divisões celulares, que são em um único plano.

Alem disso, há indícios de que as duas espécies apresentam variações morfológicas semelhantes como adaptações às condições de salinidade. Derenne et al. (1992) e Fowler et al. (2004) demonstraram que, em água doce, ambos os táxons têm superfície com abertas na parede e que, com o aumento de salinidade, as superfícies ficam mais aberturas, alem de terem mucilagem mais espessa e matéria orgânica mais rica em fenóis e com abundância de componentes alkilo-aromáticos $\mathrm{C}_{21}$ e $\mathrm{C}_{23}$.

Mesmo que Burjack (1984), Silvia \& Cornford (1985) e Faure \& Cole (1999), por exemplo, já tenham citado a ocorrência de B. brauni na Formação Assistência, estes espécimes até agora não foram submetidos a uma investigação taxonômica mais profunda, nem foram analisados no seu contexto petrográfico, o que só é possível com aplicação de lâminas delgadas. É comum o reconhecimento de microfósseis com morfologia similar aos das Figura a-f simplesmente como $B$. braunii, procedimento que tem caráter meramente operacional.

Todavia, Burn (1982) questionou a identidade biológica e ecológica que muitos pesquisadores presumiam entre os muitos $B$. braunii fósseis e o $B$. braunii moderno. Para isso, comparou exemplares atuais de $B$. braunii com microorganismos fósseis de três localidades. Em duas delas os espécimes eram atribuídos a B. braunii (torbanito da Escócia; e folhelhos pirobetuminosos ordovicianos, "Galena Oil Shale", da Austrália) e na outra, a G. prisca (kukersito siluriano da Estônia). Os espécimes das três localidades apresentaram consideráveis diferenças morfológicas não somente entre si, mas também com os exemplares atuais. Assim, o autor concluiu que os conjuntos de microorganismos fósseis das três localidades deveriam ser classificados cada um em um gênero diferente. 


\subsection{2 - Análise morfológica}

As diferenças morfológicas entre as duas espécies são bastante discretas. Gloeodiniopsis sp 1 tem parede mais lisa e mais opaca, enquanto a da Espécie 2 é mais translúcida e, em muitos exemplares, rugosa. Em comparação com Gloeodiniopsis sp 1, na maioria das vezes o número de células por colônia da Espécie 2 é maior e suas colônias têm arranjo aparentemente mais empacotado (Figuras 11-12). Já os exemplares de Gloeodiniopsis sp 1 normalmente são maiores, contudo as amplitudes dos diâmetros maiores das duas espécies têm valores coincidentes.

As pequenas diferenças de variedade morfológica entre as duas espécies permitem inferir, como ilustrado na Figura 19, que Gloeodiniopsis sp 1 tem padrão de divisão celular semelhante ao gênero atual Chroococcus e a Espécie 2 ao gênero atual Cyanosarcina.

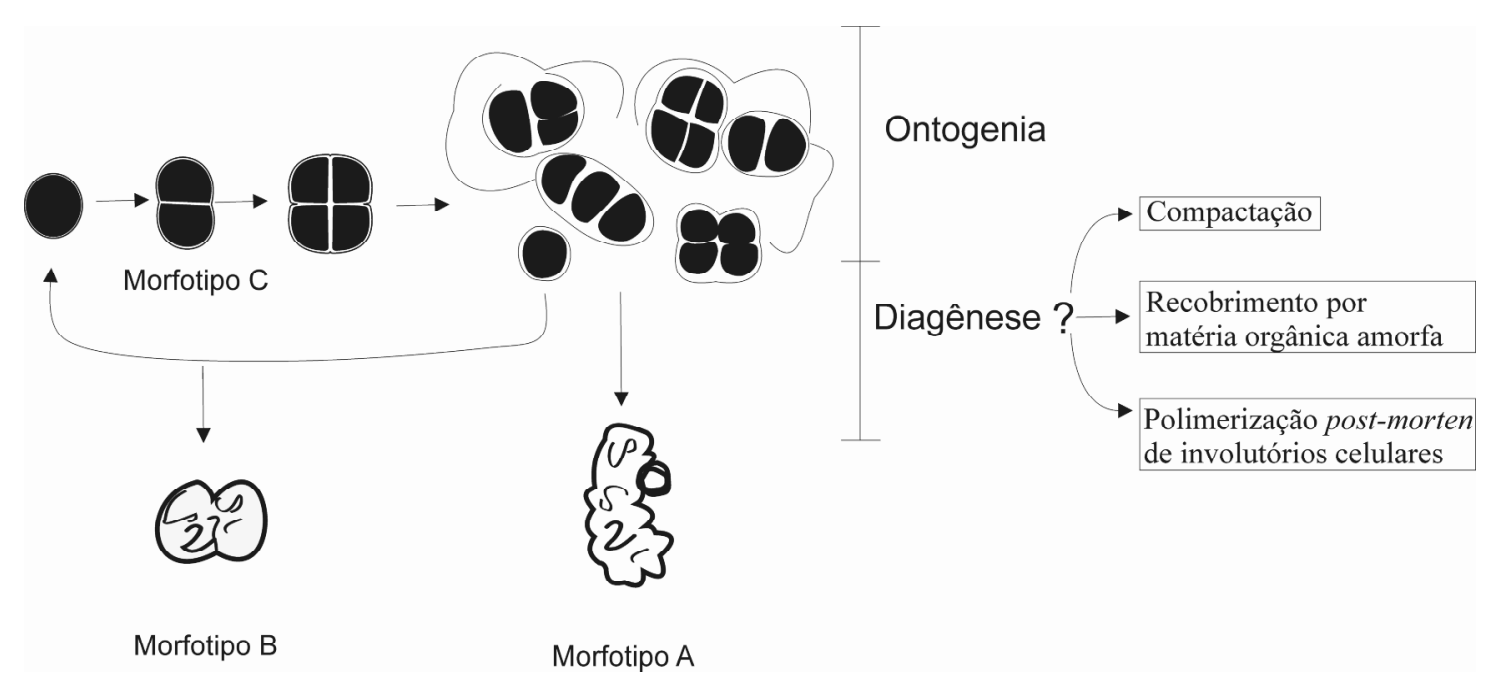

Figura 17: Reconstituição da ontogenia e da diagenese da Espécie 1. Variedade morfológica muito semelhante à do gênero moderno Gloeocapsopsis. Produtos tafonômicos similares à assembléia de Gloeocapsomorpha prisca da Bacia Baltic (Foster et al. 1989).

Figura 18: Histogramas com frequiência das classes de tamanhos para as quatro espécies descritas de cada uma de suas respectivas variantes morfológicas. Em vermelho, as linhas de tendência. 


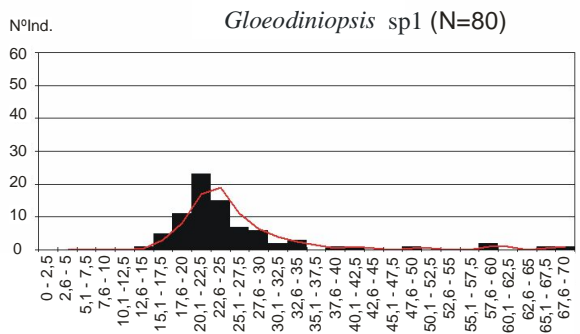

Espécie $2(\mathrm{~N}=26)$

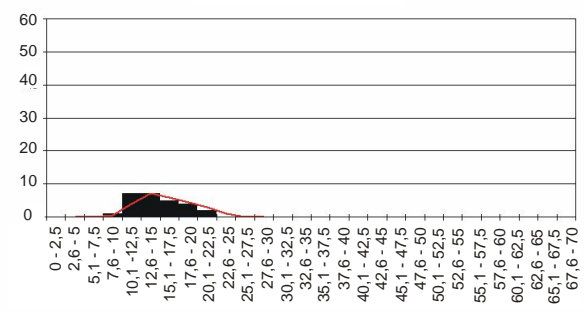

Espécie $3(\mathrm{~N}=45)$
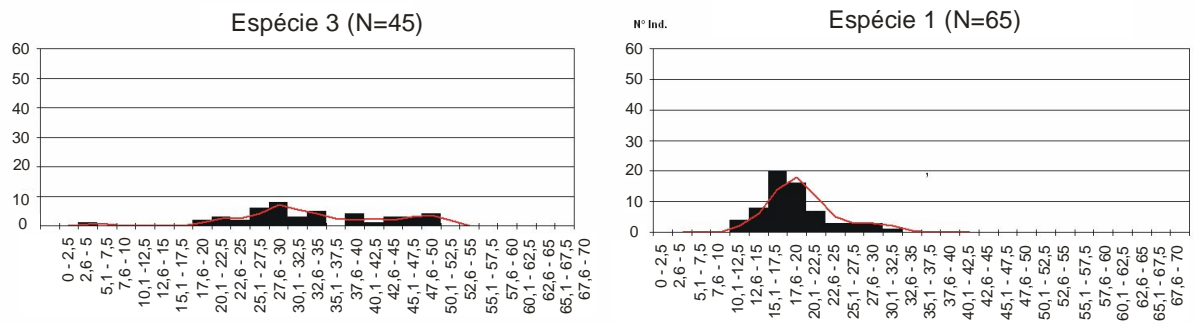

Hemisferóides

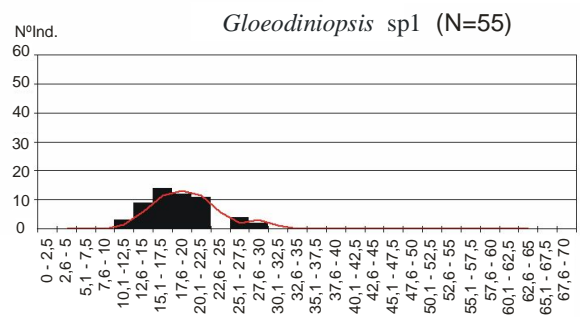

Espécie $2(\mathrm{~N}=61)$

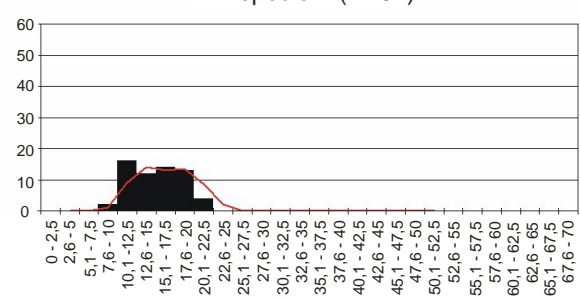

Espécie 1 (N=231)

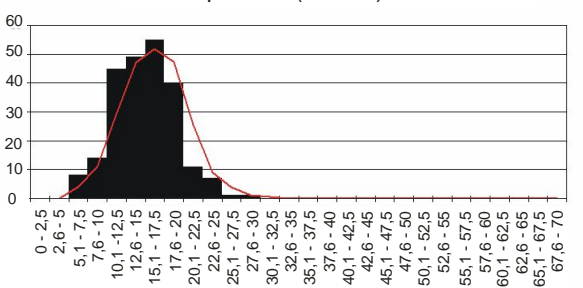

Cuneiformes

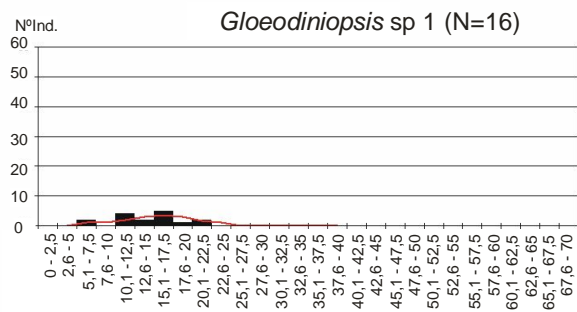

Espécie $2(\mathrm{~N}=134)$

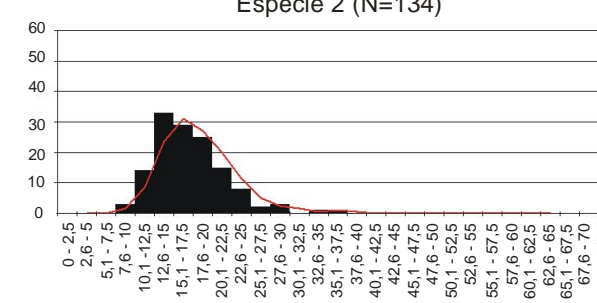

Espécie $1(\mathrm{~N}=70)$

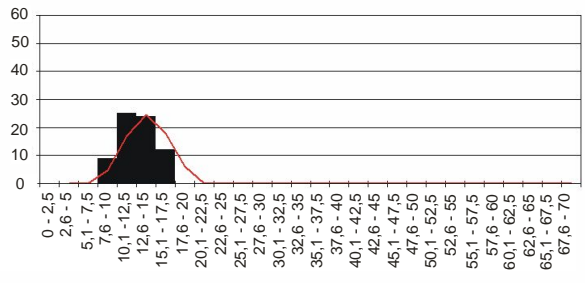




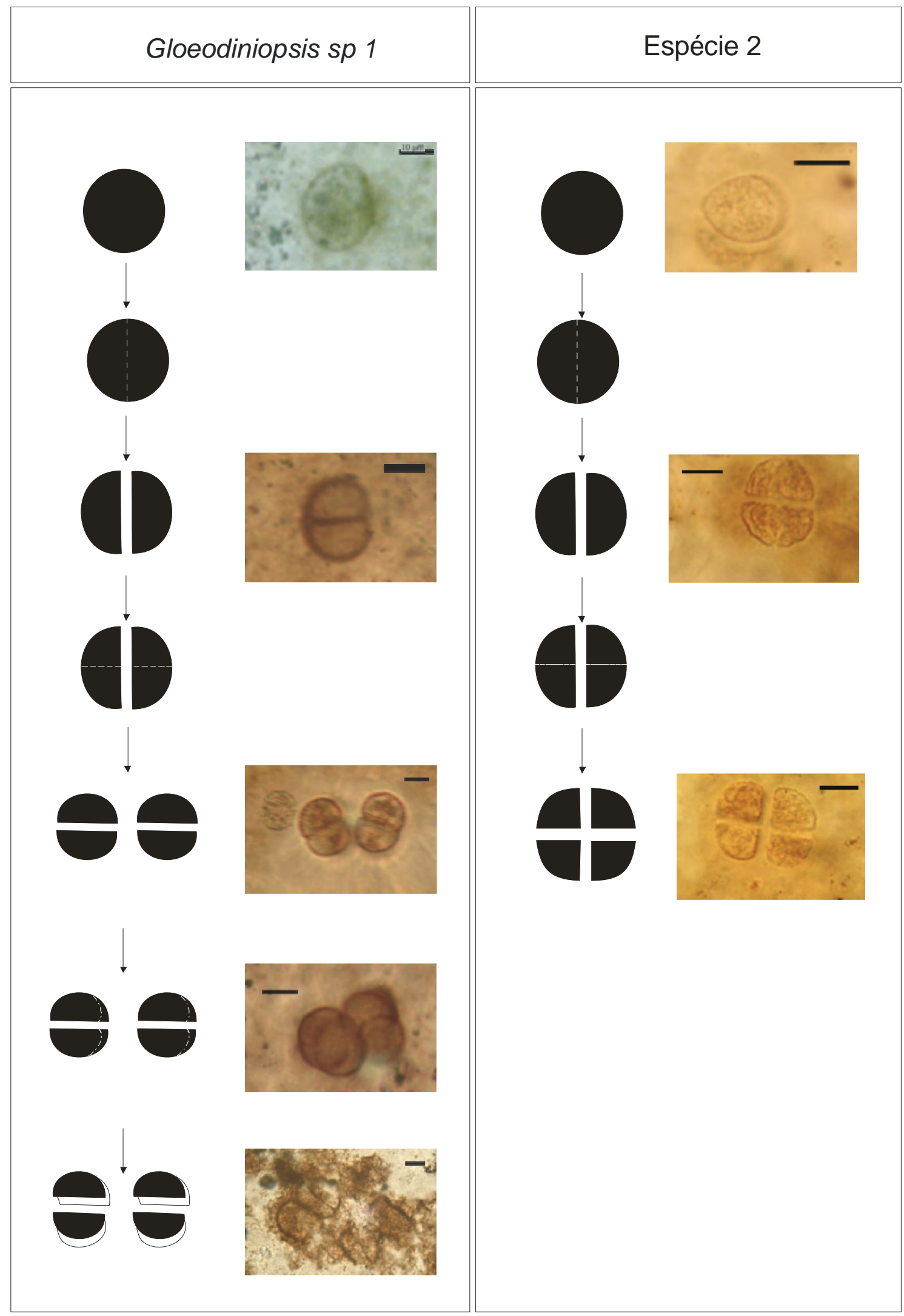

Figura 19:Reconstituição dos padrões de divisão celular das espécies 1 e 2 e Morfotipo $G$ baseada na descrição de Anagnostidis \& Komárek (1988) para cianobactérias dos gêneros Chroococcus, Cyanosarcina respectivamente. O símbolo + significa que a ocorrência de dois planos de divisão celular concomitantes. Barra $=10 \mu \mathrm{m}$. 


\subsection{3 - Tentativa de diferenciação por meios estatísticos} Justificativa

Alem das semelhanças morfológicas entre as duas espécies descritas na seção anterior, ambas são encontradas, em relativa abundância, nas localidades Estrela e Paraisolândia. Muitas vezes estão presentes na mesma lâmina.

Ao se separar as linhas de tendência referentes às distribuições de classes de diâmetros maiores de Gloeodiniopsis sp 1 e da Espécie 2 (Figura 20) percebe-se que elas se cruzam em uma dada posição nos gráficos para as formas subesferóide e hemisferóides, e coincidem totalmente nos gráficos para as formas cuneiformes. Por isso, as diferenças na variabilidade de frequiências de tamanho entre as duas populações não são facilmente notáveis ao microscópio óptico.

\section{Procedimento estatístico}

As variações entre os parâmetros Dmáx e Dmin, ou D1 e D2 (ver Figura 8) das duas espécies foram comparadas separadamente, para as formas subesférica, hemisferóides e cuneiformes, por meio dos seguintes métodos estatísticos:

a) distribuição quantitativa das razões Dmáx/Dmin e D1/D2 nas populações (Figuras 21):

Procedimento que avaliou a esfericidade das células, de forma que quanto mais estes valores forem próximos a 1, mas esférica é a célula.

b) análise bivariante (Figura 20)

As linhas de crescimento (Imbrie 1959), que representam a variação entre Dmáx e Dmin, ou D1 e D2, foram expressas por equações do tipo $y=a x+b$. O ângulo de declive $(a)$, que representa a razão entre duas taxas de crescimento, e o ângulo de inclinação ou índice de crescimento inicial $(\alpha)$, que é o valor de $y$ quando $x=1$, foram calculados para cada linha de crescimento, da seguinte maneira:

$$
\begin{gathered}
a=\mathrm{S}_{\mathrm{y}} / \mathrm{S}_{\mathrm{x}} \\
\alpha=\arctan \left(\mathrm{S}_{\mathrm{y}} / \mathrm{S}_{\mathrm{x}}\right)
\end{gathered}
$$


Onde $\mathrm{S}_{\mathrm{y}}=$ desvio padrão da variante $y(\mathrm{Dmin}) ; \mathrm{S}_{\mathrm{x}}=$ desvio padrão da variante $x$ (Dmáx)

Os níveis de correlação linear $(r)$ foram representados pela equação:

$$
r=\frac{\sum(x-\bar{x})(y-\bar{y})}{\sqrt{\sum(x-\bar{x})^{2} \sum(y-\bar{y})^{2}}}
$$

c) médias aritméticas de Dmáx e o intervalo de confiança das populações (Figura 22)

Procedimento que avaliou médias aritméticas de Dmáx e os $45 \%$ dos valores maiores e menores que a média aritmética, denominado intervalo de confiança.

d)Box-plot de Dmáx de cada população (Figura 23)

Procedimento que avaliou as distribuições de valores em relação à mediana em quartis $(\mathrm{Q}=$ um quarto dos valores) e os limites máximo $(\mathrm{Q} 3+1,5)$ e mínimo $(\mathrm{Q} 1-1,5)$.

e) coleta de dados substitutos (Magalhães \& Lima 2001) (Figura 24)

Para comparar os padrões de distribuição de frequiência de valores de diâmetro máximo nas populações de dados de cada espécie separadamente (Figuras 18 e 20) com os mesmos padrões de ambas as espécies conjuntamente (como se fossem apenas uma só), plotaram-se dados tomados aleatoriamente, e em igual número, referentes à população de dados de frequiência de diâmetro máximo das duas espécies (Figura 24).

\section{Avaliação dos resultados e discussão}

A maior concentração de valores de razões Dmáx/Dmin próximas a 1,0 nas células subesférica da Gloeodiniopsis sp 1 (Figura 21) mostra que esta espécie é ligeiramente mais esférica do que Espécie 2.

O fato de que o ângulo de declive (a) para todas as formas está próximo a 1,0 (Tabela 5), evidenciando que as relações entre Dmáx e Dmin mantiveram-se relativamente 
regulares durante o crescimento celular. Mesmo que os valores Dmáx entre as duas espécies sejam coincidentes (Figura 20), as linhas de crescimento para cada um são consideravelmente distintas (Figura 23).

Alem disso, os padrões gráficos que demonstram os intervalos de confiança das médias aritméticas e os quartis (Figuras 22-23) indicam que as diferentes populações podem ser separadas estatisticamente.

Os histogramas de freqüência das classes de tamanhos da Figura, que representam junções das populações de dados das duas espécies, diferentemente dos histogramas das medidas individuais da Figura 24, não são unimodais, ou seja, não têm distribuição normal (Magalhães \& Lima 2001), o que é mais um indício de que a população de dados seja proveniente de duas espécies biológicas.

Assim, as pequenas diferenças morfológicas são reforçadas com a análise estatística, indicando que o conjunto de dados deve pertencer a duas espécies biológicas. 


\section{Subesféricas}

$\mathrm{N}^{\circ}$ Ind.

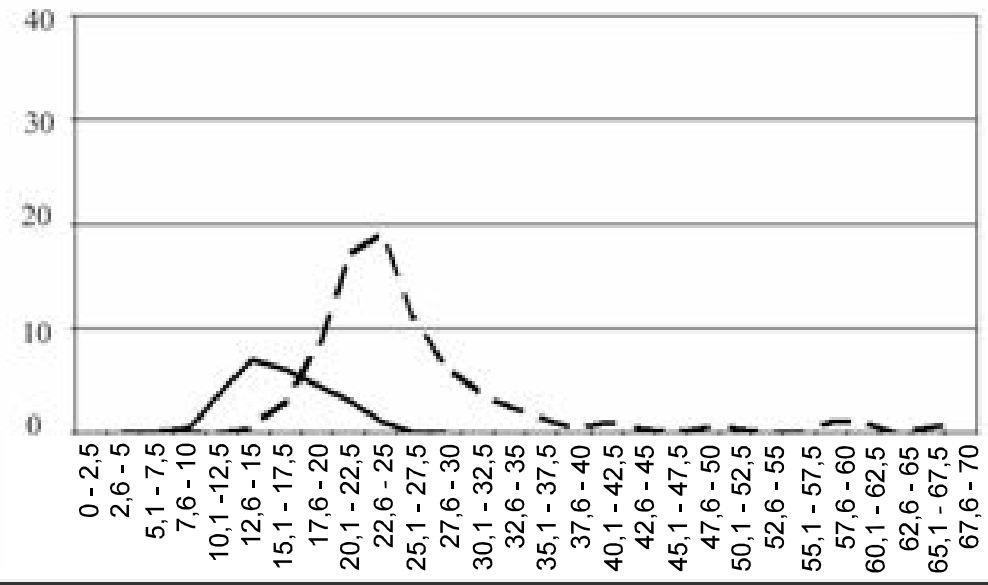

- - Gloeodiniopsis sp 1

Espécie 2

Gloeodiniopsis sp $1 \mathrm{~N}=45$

Espécie $2 \mathrm{~N}=65$

\section{Hemisferóides}

$\mathrm{N}^{\circ}$ Ind.

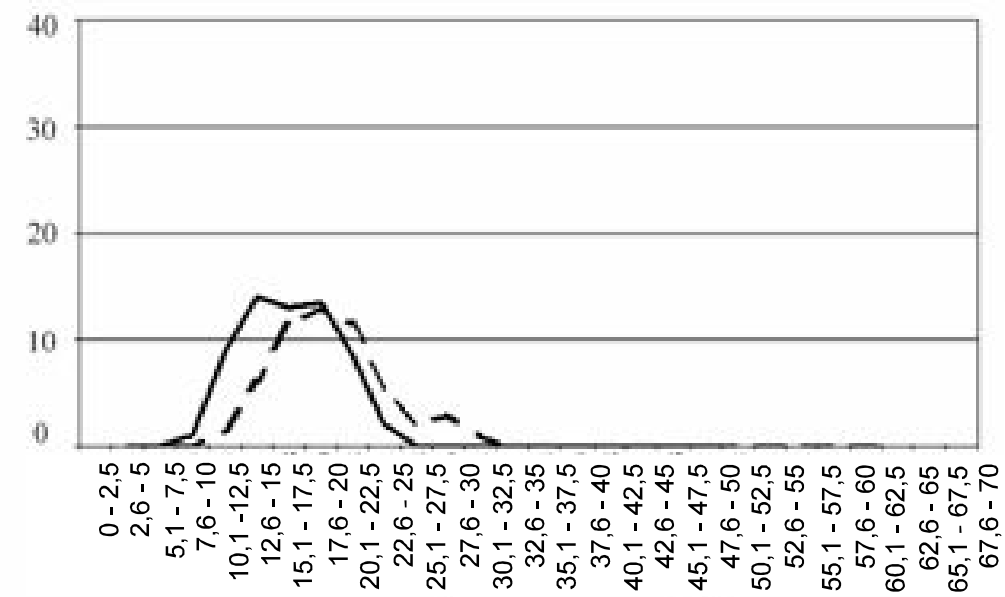

Gloeodiniopsis sp $1 \mathrm{~N}=58$

Espécie $2 \mathrm{~N}=26$

\section{Cuneiformes}

\section{$\mathrm{N}^{\circ}$ Ind.}

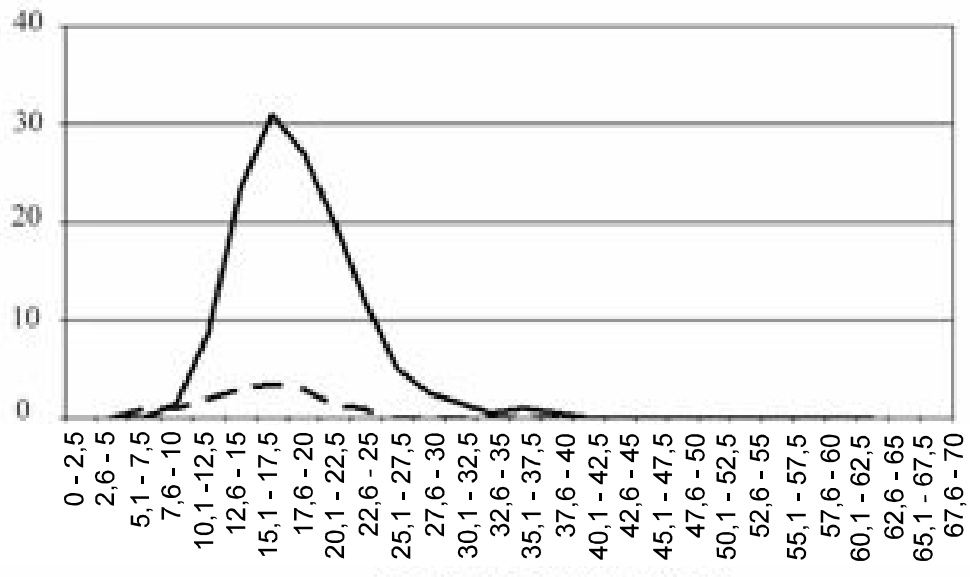

Gloeodiniopsis sp $1 \mathrm{~N}=78$

Espécie $2 \mathrm{~N}=70$

Figura 20: Linhas de tendência de valores de diâmetros maiores (em freqüência das classes) para as diferentes morfologias celulares de Gloeodiniopsis sp 1 e da Espécies 2. 


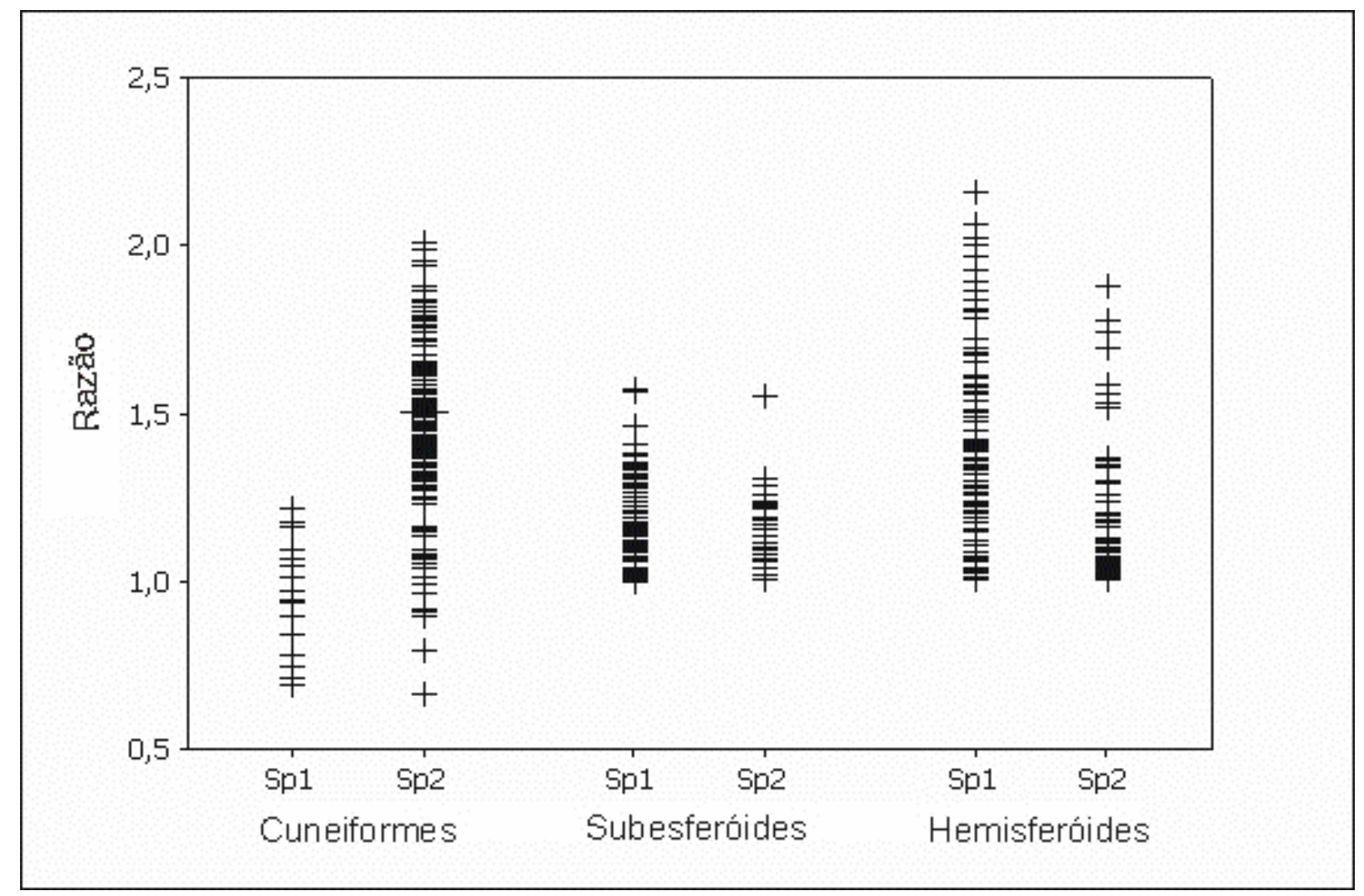

Figura 21: Diferentes razões Dmáx/Dmin (células subesferóide e hemisferóides) ou D1/D2 (células cuneiformes) para as três morfologias celulares encontradas na Gloeodiniopsis sp 1 (Sp1) e na Espécie 2 $(\mathrm{Sp} 2)$.

Tabela 5: Dados da análise estatística bivariante para formas subesféricas classificadas como Gloeodiniopsis sp 1 e Espécie 2. Variáveis: N = Número de indivíduos, $\mathrm{x}=$ Diâmetro máximo (Dmáx), $\mathrm{y}=$ Diâmetro mínimo (Dmin). $\overline{\mathrm{x}}=$ Média aritmética de Dmáx; $\bar{y}=$ Média aritmética de Dmin. $a=$ Declive da linha de crescimento. $\sigma_{\mathrm{a}}=$ Desvio padrão de a. $\mathrm{b}=$ Índice de crescimento inicial. $\alpha\left({ }^{\circ}\right)=$ Ângulo de aclive. $r=$ Coeficiente de correlação de $\mathrm{x}$ e $\mathrm{y} . \mathrm{S}_{\mathrm{x}}=$ Desvio padrão de $\mathrm{x} . \mathrm{S}_{\mathrm{y}}=$ Desvio padrão de $\mathrm{y} . \mathrm{S}_{\mathrm{d}}=$ Desvio padrão da distancia diagonal. $S_{\mathrm{k}}=$ Desvio padrão da distancia vertical.

\begin{tabular}{|c|c|c|c|c|c|c|}
\hline & \multicolumn{2}{|c|}{ Subesférica } & \multicolumn{2}{c|}{ hemisferóides } & \multicolumn{2}{c|}{ cuneiformes } \\
\cline { 2 - 7 } & $\begin{array}{c}\text { Gloeodiniopsis } \\
\text { sp 1 }\end{array}$ & $\underline{\text { Espécie 2 }}$ & $\frac{\text { Gloeodiniopsis }}{\underline{\text { s 1 }}}$ & $\underline{\text { Espécie 2 }}$ & $\frac{\text { Gloeodiniopsis }}{\underline{\text { sp 1 }}}$ & $\underline{\text { Espécie 2 }}$ \\
\hline $\mathrm{N}$ & 80 & 27 & 79 & 61 & 16 & 134 \\
\hline$\overline{\mathrm{x}}$ & 19,449 & 9,513 & 17,708 & 13,433 & 6,422 & 13,827 \\
\hline$\overline{\mathrm{y}}$ & 16,051 & 8,282 & 12,962 & 11,233 & 6,298 & 9,638 \\
\hline$a$ & 0,723 & 0,961 & 1,004 & 0,993 & 1,112 & 0,676 \\
\hline$b$ & 1,985 & $-0,863$ & $-4,821$ & $-2,108$ & $-0,844$ & 0,294 \\
\hline$\alpha\left(^{\circ}\right)$ & 0,626 & 0,766 & 0,788 & 0,782 & 0,838 & 0,594 \\
\hline$r$ & 0,908 & 0,903 & 0,756 & 0,674 & 0,822 & 0,805 \\
\hline $\mathrm{S}_{x}$ & 10,503 & 3,259 & 4,869 & 3,210 & 3,777 & 4,693 \\
\hline $\mathrm{S}_{y}$ & 7,596 & 3,133 & 4,890 & 3,189 & 4,201 & 3,171 \\
\hline $\mathrm{S}_{\mathrm{d}}$ & 5,554 & 1,992 & 4,819 & 3,655 & 3,371 & 3,540 \\
\hline $\mathrm{S}_{\mathrm{k}}$ & 2,357 & 1,412 & 2,195 & 1,912 & 1,836 & 1,881 \\
\hline
\end{tabular}




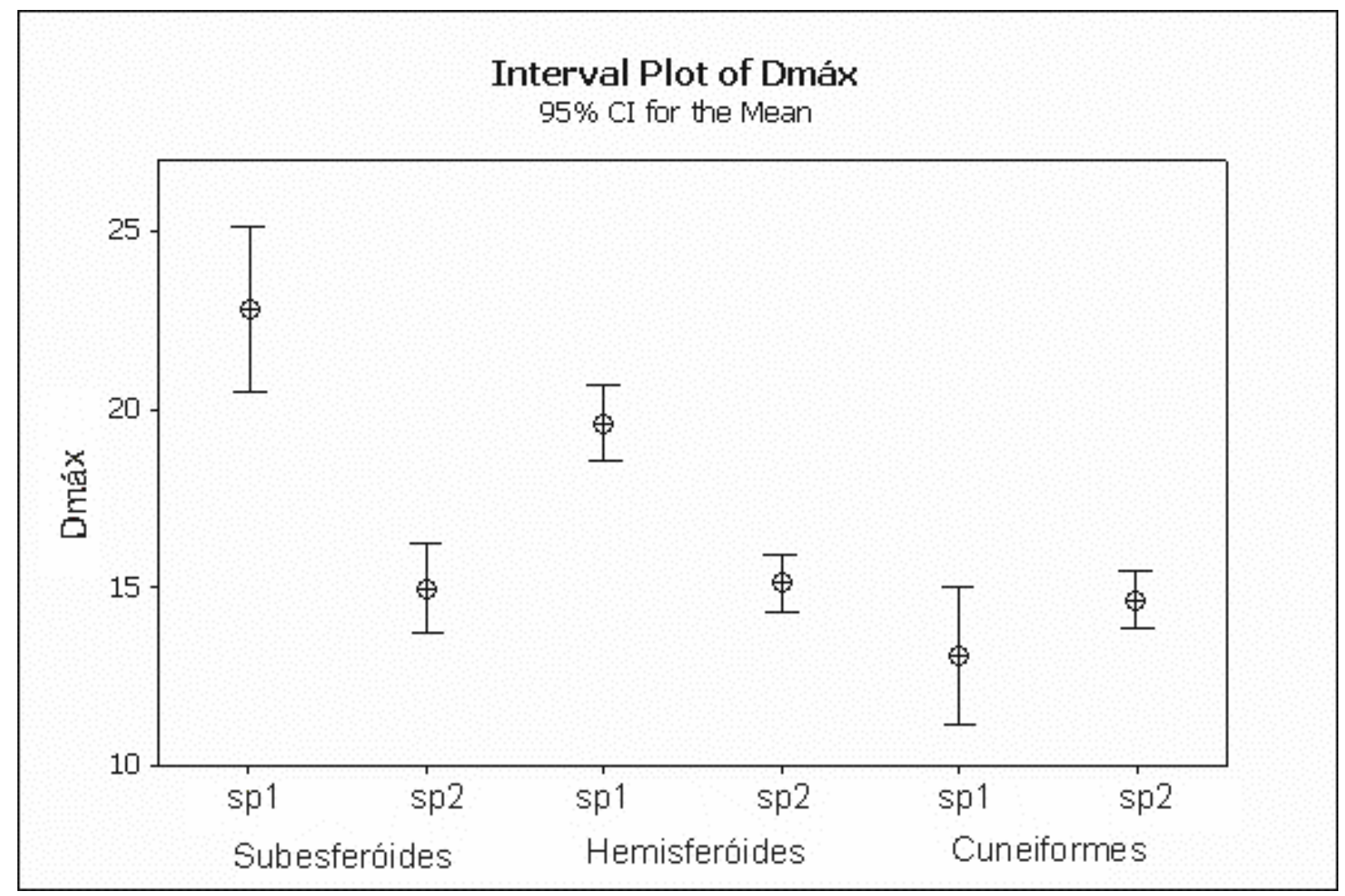

Figura 22: Médias aritméticas de Dmáx e o intervalo de confiança de cada população de dados para as variantes de forma celular das espécies 1 e 2 (sp1 e sp2).

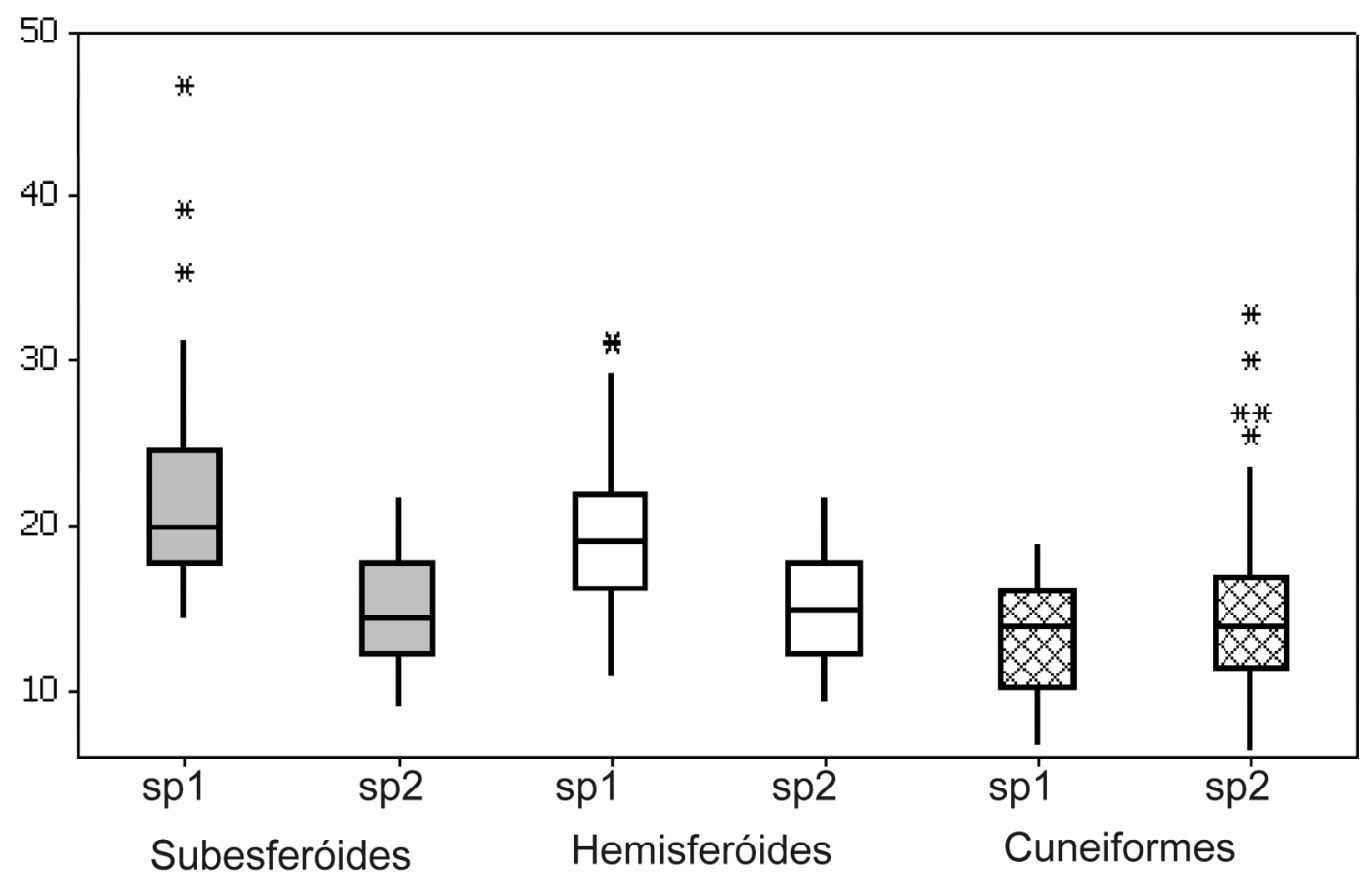

Figura 23: Box-plot do Dmáx das populações de dados da Gloeodiniopsis sp 1 e da Espécie 2. * = valores discrepantes 

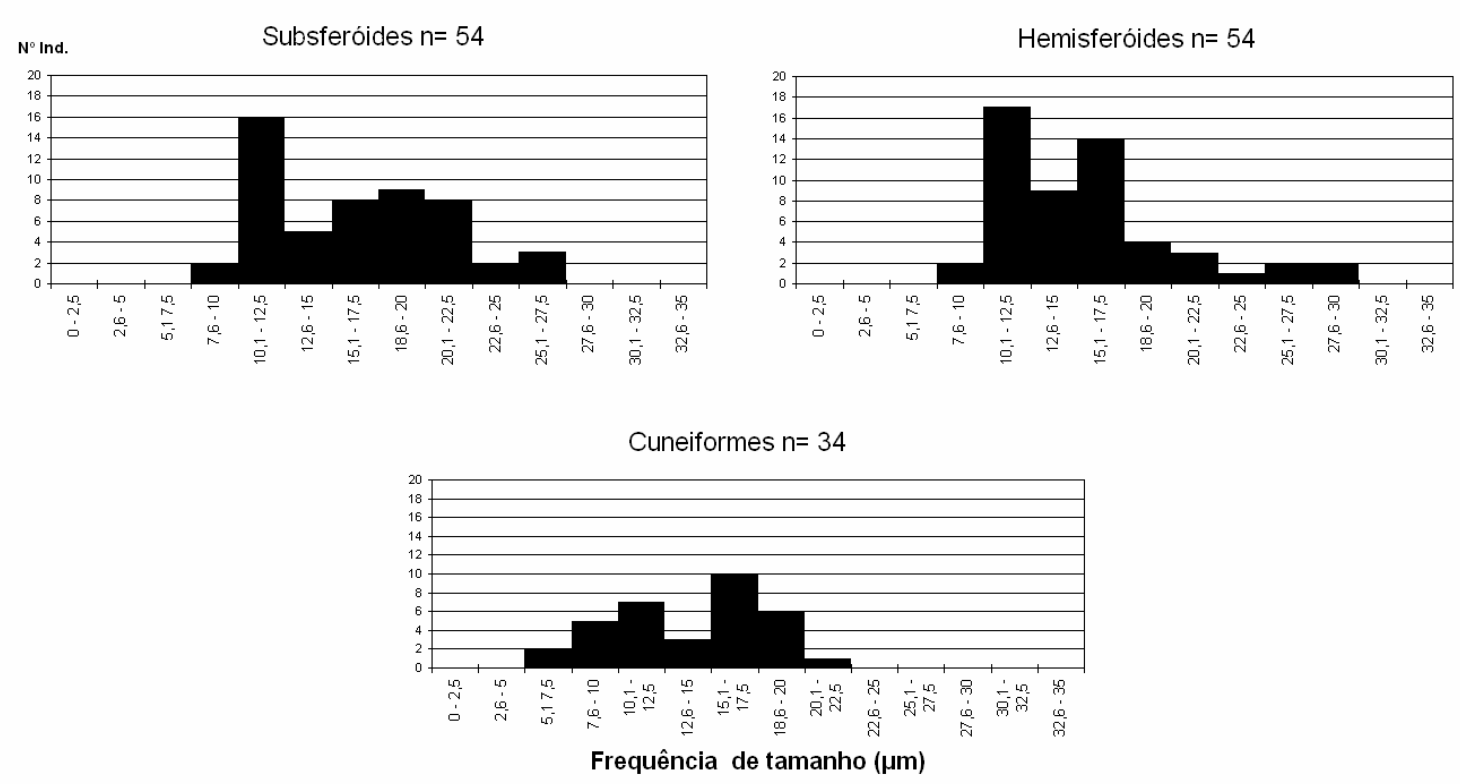

Figura 24: Histogramas com coleta de dados substitutos, nos quais foram plotados dados escolhidos aleatoriamente e em igual número, referentes às freqüências de classes de tamanho da Gloeodiniopsis sp 1 e da Espécie 2, simulando a situação de que os dados representassem apenas uma espécie. Assim, para os gráficos das formas subesféricas e memisferóides, por exemplo, que têm 54 indivíduos mensurados, 27 pertencem à Gloeodiniopsis sp 1 e outros 27 a Espécie 2. Observa-se que nenhum apresenta distribuição normal (monomodal).

\section{3 - Espécie 3: Reconhecimento de uma espécie polimórfica}

O terceiro problema comum a praticamente toda investigação de microorganismos fósseis em sílex envolve o reconhecimento de relações ontogênicas entre os diversos morfotipos presentes na assembléia. A questão básica é se o número de morfotipos seria igual, menor ou maior que o número de espécies biológicas na comunidade original. A caracterização de diversos morfotipos é uma maneira prática de lidar com a variedade evidente em qualquer tafocenose microbiana, e para fins operacionais, o paleontólogo pode batizar cada um com o nome formal que quiser. Foi esse o sistema adotado por Barghoorn \& Tyler (1965), Schopf (1968) e Schopf \& Blacic (1971) nos estudos iniciais de microbiotas pré-cambrianas. Naquela época, pensava-se que cada morfotipo corresponderia, a grosso modo, a uma espécie biológica. Como discutido acima na seção 4.4, estudos posteriores demonstraram que associação constante de determinados morfotipos permitia reconhecer conjuntos de morfotipos que poderiam representar diferentes estágios de desenvolvimento 
do ciclo de vida de uma espécie biológica. O exemplo clássico deste tipo de abordagem é de Knoll \& Golubić (1979), que emendaram a diagnose do gênero Gloeodiniopsis Schopf, 1968, para englobar os gêneros Bigeminococcus Schopf \& Blacic, 1971, Eozygion Schopf \& Blacic, 1971, Eotetrahedrion Schopf \& Blacic, 1971, e parte do gênero Caryosphaeroides Schopf, 1968. De maneira análoga, reconheceu-se na microbiota da Formação Assistência a espécie polimórfica Espécie 3, constituída pelos morfotipos D, E e F.

Considera-se que os três morfotipos (Figura 13) são variantes de uma única espécie porque (i) os Morfotipos E e F ocorrem nas lâminas GP/L-6E 8 e GP/L-6E 23, juntamente com o Morfotipo D, o mais abundante dos três, e (ii) porque os três se assemelham, cada um a um fase da ontogênia da ordem de clorófitas Chlorococcales (Lee 1980, Tappan 1980, Daugbjerg et al. 2000, Shubert 2003, Bicudo \& Menezes 2005) (Figura 25).

Uma das características desta ordem é a presença de zoósporos e gametas, que são células reprodutivas móveis, e que, na maioria das vezes, são morfologicamente indistinguíveis. Em muitas espécies, estas células são formadas por múltiplas clivagens protoplasmáticas dentro de uma parede celular comum (Shubert 2003), formando estruturas como os aplanosporos (Lee 1980), que são esporos não móveis (Reviers 2006). Morfotipo E têm morfologia indicativa de origem a partir de células reprodutivas móveis de Chlorococcales que devem ter perdido os flagelos e o protoplasma devido à degradação e com aplanosporos. Já a espessura e a abertura na parede do Morfotipo F indicam que os espécimes representem aplanosporos.

Considerando a delicadeza, é muito pouco provável que o protoplasma ou flagelos sejam preservados. Francis et al. (1978) relataram células flageladas do gênero Pyramimonas artificialmente silicificadas, processo presumivelmente muito mais rápido do que qualquer processo natural de silicificação. Mesmo assim não foram todos os espécimes que conservaram os flagelos.

Portanto, a região achatada do Morfotipo E (Figuras 13 g-j) pode corresponder à região de inserção do flagelo, que não teria sido preservado. Interpretação semelhante foi proposta por Bernardi-Campesi et al. (2004) para os microorganismos fósseis cretáceos silicificados, classificados no gênero Chlorella, também esféricos com uma região mais achatada, que teriam possíveis flagelos. Conforme reconstituição apresentada na Figura 26, muitos táxons da ordem Chlorococcales têm células vegetativas esféricas e solitárias, bem como variantes reprodutivas flageladas e aplanósporos, como por exemplo Bracteacoccus, Dictyochloropsis e Chlorococcum. Já o gênero Neochloris, alem destas características, tem zoósporos biflagelados que tomam a forma esféricas durante quiescencia. Como as células 
reprodutivas inferidas da Espécie 3 são esferóides (Morfotipo E), este parece ser o gênero moderno morfologicamente mais próximo à Espécie 3.

\section{Aplanosporo Célula Reprodutiva Célula vegetativa}

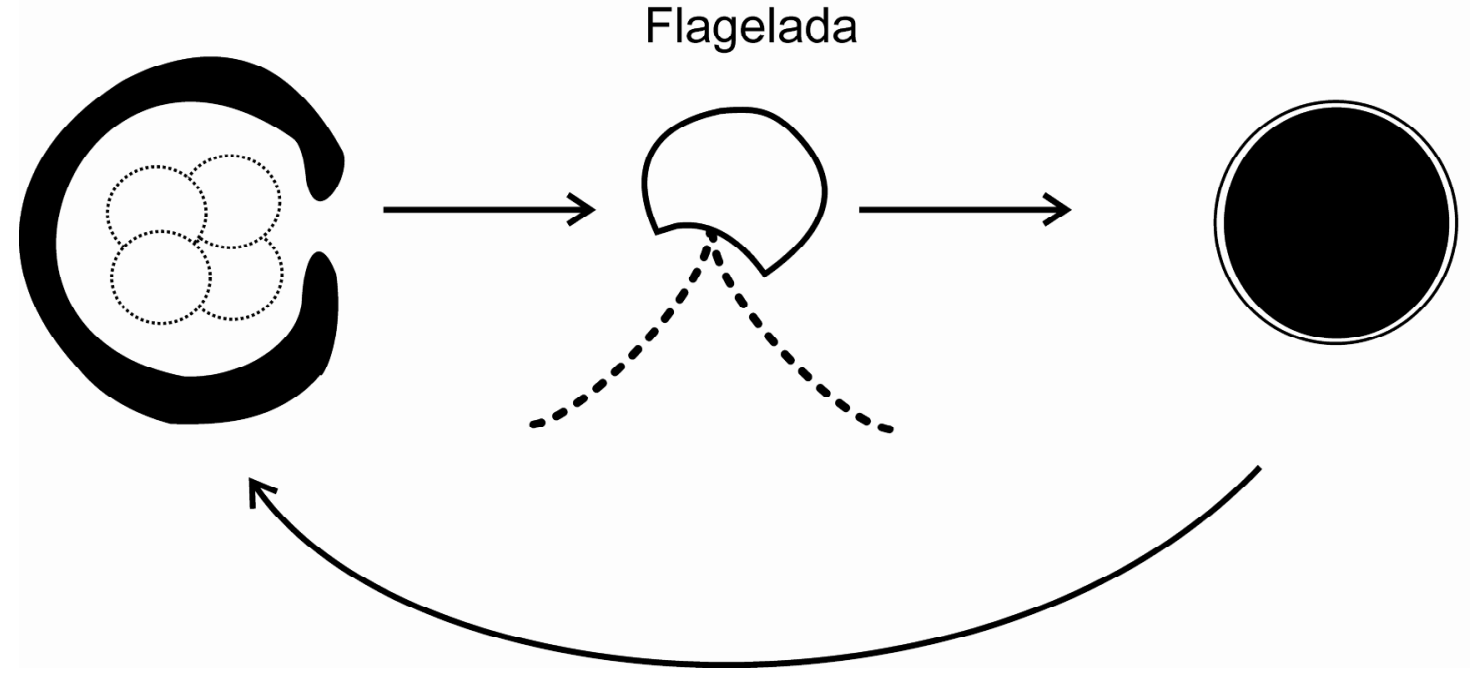

Figura25: Reconstituição do ciclo ontogenético para Espécie 3, que demonstra a formação de zoósporos a partir de possíveis quatro células filhas durante reprodução assexuada. Estruturas listradas não observadas, apenas inferidas. 


\section{7 - PALEONTOLOGIA SISTEMÁTICA}

Todos os microfósseis descritos aqui ocorrem em lâminas delgadas de sílex da Formação Assistência, de idade permiana (Série Cisuraliano, Andar Artinskiano), depositadas na coleção do Laboratório de Paleontologia Sistemática do IGc-USP, São Paulo, sob as siglas GP/L-G6 1 a 69. As localidades de coleta e a distribuição estratigráfica das amostras laminadas estão listadas nas Tabelas 2 e 3. A sistemática adotada aqui é baseada nos trabalhos de Komárek \& Hauer (2004) e Woese \& Fox (1977).

Reino Eubacteria Woese \& Fox, 1977

Filo CyAnobacteria Stanier et al., 1978

Classe Coccogoneae Thuret, 1875

Ordem Chroococcales Wettstein, 1924

Família ?EnTophysalidaceAe Geitler, 1925

Espécie 1

Figura 10, 16, 17, 18 Tabela 3, 4 Seção 6.1

\section{Descrição}

Espécie unicelular polimórfica, predominantemente colonial, composta pelos morfotipos A, B e C. Morfotipos A e B têm invólucro translúcido de coloração marromalaranjada. Morfotipo C apresenta bainha fina, bem definida e coloração variada. Morfotipo A é colonial de forma irregular, com limites dos invólucros individuais comumente indistintos. Morfotipo B é composto por células subesférica, solitárias ou em grupos de até 8 unidades. Morfotipo C consiste de células cuneiformes até esferóides, em colônias densamente agregadas, de 2 a 14 indivíduos. Médias dos diâmetros máximos das células nos três morfotipos variam entre 13,6 e 18,6 $\mu \mathrm{m}$.

Material: Localidade Paraisolândia 1, Camada das Dobras Enterolíticas, Níveis 1-3. Camada Bairrinho, Nível 8, Camada de Ritmitos Superiores, Níveis 19 e 21. Lâminas: GP/L-G6 2, GP/L-G6 4, GP/L-G6 6, GP/L-G6 7, GP/L-G6 9, GP/L-G6 10, GP/L-G6 11. 
Morfotipo A (Figuras 10 a-f)

Colônias com formas não muito definidas, algumas mais cilíndricas, lembrando fileiras (Figuras $13 \mathrm{a}-\mathrm{c}$ ), e outras mais globulares (Figuras $10 \mathrm{~d}$-f). Limites celulares indistintos. Superfície colonial aparentemente lisa. Diâmetro colonial de 23,7 a 122,9 $\mu \mathrm{m}$, com média de 50,3 $\mu \mathrm{m}(\mathrm{N}=37)$

Morfotipo B (Figuras $10 \mathrm{~g}-\mathrm{j}$ )

Células subesférica, solitárias ou em colônias de até oito unidades. Superfície celular aparentemente lisa. Diâmetro celular de 7,5 a 39,4 $\mu \mathrm{m}$, com média de 18,6 $\mu \mathrm{m}(\mathrm{N}=35)$.

Morfotipo C (Figuras $10 \mathrm{k}-\mathrm{o})$

Células subesféricas, hemisferóides ou cuneiformes, agregadas em duplas, quartetos ou conjuntos de até quatorze unidades. Colônias densamente agregadas, muitas com mais de uma forma e arranjo celular. Bainha fina e conspícua em muitos exemplares, formando envelope que engloba duas, três ou quatro células. Diâmetro máximo das células subesféricas de 9,2 a 29,7 $\mu \mathrm{m}$, com média de 13,6 $\mu \mathrm{m}(\mathrm{N}=66)$; diâmetro máximo das células hemisferóides de 6,4 a 28,0 $\mu \mathrm{m}$, com média de 15,0 $\mu \mathrm{m}(\mathrm{N}=232)$; diâmetro máximo das células cuneiformes de 8,7 a 16,5 $\mu \mathrm{m}$, com média de 15,8 $\mu \mathrm{m}(\mathrm{N}=71)$.

\section{$\underline{\text { Discussão }}$}

Como discutido na Seção 6.1, os três morfotipos foram considerados o mesmo táxon porque, na maioria das vezes, observou-se estas variantes juntas na mesma lâmina, e poucas vezes com outros microorganismos fósseis. Em nenhuma lâmina que continha espécimes do Morfotipo $\mathrm{C}$ se observou outro tipo de microorganismos que não fossem os Morfotipos $\mathrm{A}$ e B.

O Morfotipo B apresenta coloração, tamanho, contorno e resíduos internos muito semelhantes a microorganismos fósseis já reconhecidos como B. braunii (Silva \& Cornneford, 1985) ou como organolitas (Rodrigues \& Amaral 1983)

Considera-se o gênero atual Gloeocapsopsis Geitler 1925 equivalente morfológico mais próximo da Espécie 1, pois apresenta colônia envolta por uma bainha fina e com 
limites bem nítidos, e células subesférica, hemisferóides e irregulares (Komárek 2003; Komárek \& Hauer; 2004).

Família ChroOcocCACEAe Nägeli 1849

Gênero Glozodiniopsis Schopf, 1968, emend. Knoll \& Golubić, 1979

Espécie-tipo: Gloeodiniopsis lamellosa Schopf, 1968, emend. Knoll \& Golubić, 1979

Descrição genérica (traduzida livremente de Knoll \& Golubić, 1979, p. 147): Esferóides e elipsóides com contornos únicos, duplos ou múltiplos, solitários ou em grupos de 2, 3, 4, ou até 8 indivíduos dentro de uma bainha comum. Contornos externos predominantemente arredondados; contornos internos arredondados, constritos no meio ou poliédricos.

Gloeodiniopsis aff. Gloeodiniopsis lamellosa Schopf, 1968, emend. Knoll \& Golubić, 1979

Figuras 14 a-d Tabelas 3, 4

\section{$\underline{\text { Descrição }}$}

Células hemisferóides em duplas, com aspecto delicado, sem parede preservada, bainha mucilaginosa colonial espessa. Aparentemente número de células por colônia múltiplo de 2 (2, 4, 8 etc.). Algumas colônias com arranjo planar, com envelope unilamelar. Diâmetro máximo das células de 9,9 a 18,8 $\mu \mathrm{m}$, com média de 12,8 $\mu \mathrm{m}(\mathrm{N}=6)$. Bainha celular com espessura entre 3,5 e 4,4 $\mu \mathrm{m}$ e média de $4,0 \mu \mathrm{m}(\mathrm{N}=2)$.

Material: Localidade Estrela, Camada de Dobras Enterolíticas, Nível 3, lâminas GP/L-G6 21, GP/L-G6 22.

\section{Discussão}

Schopf \& Blacic (1971) descreveram duas espécies deste gênero Eozygion (Neoproterozóico - Austrália) que são morfologicamente muito parecidas com Gloeodiniopsis aff. G. lamellosa. Eozygion grande Schopf \& Blacic 1971 e Eozygion minutum Schopf \& Blacic 1971, compreendem duplas de células hemisferóides envoltas por uma espessa bainha comum, sem evidencias da parede celular. Estas espécies diferem apenas em tamanho, com médias de diâmetro máximo de $13,4 \mu \mathrm{m}$ e $8,2 \mu \mathrm{m}$ e bainhas com 
espessuras entre 1,5 e $4 \mu \mathrm{m}$ e 1,7 e $1,8 \mu \mathrm{m}$, respectivamente, valores parecidos com os obtidos no presente trabalho (diâmetro médio de $12,8 \mu \mathrm{m}$ e bainhas entre 3,5 e 4,4 $\mu \mathrm{m}$ de espessura).

Exemplares de E. minutum descritos do Paleoproterozóico do Canadá por Hofmann (1976) também consistem de duplas de células exclusivamente hemisferóides envolvidas por um envelope comum, o que é parecido com o material da Formação Assistência. Diferem, contudo, dos microorganismos fósseis descritos aqui por serem um pouco menores (tamanho celular máximo de $9 \mu \mathrm{m}$ ), e apresentarem bainha mais fina.

O arranjo planar de alguns dos exemplares do presente trabalho diferencia o táxon descrito aqui não somente de E. grande e E. minutum, como também de todos os Gloeodiniopsis lamellosa já descritos. Alem disso, caracteres comuns em muitas descrições de G. lamellosa (p ex. Schopf 1968, Knoll e Golubić 1979, Nyberg \& Schopf 1984; Kumar \& Srivastava 1992), como células subesférica, bainhas multilameladas e parede celular conspícua, não foram observados nos exemplares da Formação Assistência. Algumas duplas com células hemisferóides de G. lamellosa descritos por Sergeev (1994) do (Mesoproterozoico - Russia) também estão envolvidas por um envelope unilamelar, porém com a parede celular opaca presente e circundada por uma bainha aparentemente menos espessa (medidas não relatadas) do que no material daqui.

Cabe lembrar aqui que Knoll \& Golubić (1979) suprimiram o gênero Eozygion como sinônimo do gênero Gloeodiniopsis, o que justifica esta comparação com membros deste gênero. Pelo exposto fica evidente que o material da Formação Assistência é comparável à espécie Gloeodiniopsis lamellosa, mas provavelmente não pertence a ela.

\section{Gloeodiniopsis sp 1}

Figuras 11, 18, 20, 21, 22, 23, 24 Tabelas 3, 4, 5 Seção 6.2

\section{Descrição}

Espécie unicelular colonial, com células subesféricas, hemisferóides e cuneiformes, solitárias ou em conjuntos de 2, 3, 4, 6 ou 8 indivíduos. Algumas colônias aparentam ter arranjo cubóide (Figuras 11 j-1, n-o). Parede celular lisa, nítida, de coloração marrom a negra. Bainha ausente ou pouco evidente. Diâmetro máximo das células subesféricas de 14,3 a 39,3 $\mu \mathrm{m}$, com média de 22,8 $\mu \mathrm{m}(\mathrm{N}=78)$. Diâmetro máximo das células hemisferóides de 
10,9 a 29,3 $\mu \mathrm{m}$, com média de 17,8 $\mu \mathrm{m}(\mathrm{N}=58)$. Diâmetro máximo das células cuneiformes de 6,6 a $22,3 \mu \mathrm{m}$, com média de $14,4 \mu \mathrm{m}(\mathrm{N}=17)$.

Material: Localidade Estrela, Paraisolândia 1, Soldeira Estrada, Camada de Dobras Enterolíticas, Localidade Assistência, Camada Bairrinho. Níveis 1-3, 7 lâminas delgadas GP/L-G6 21, GP/L-G6 22, GP/L-G6 23, GP/L-G618, GP/L-G6 19, GP/L-G6 60, GP/L-G6 3, GP/L-G6 4 , GP/L-G6 7, GP/L-G6 13, GP/L-G6 30.

\section{$\underline{\text { Discussão }}$}

A presença de conjuntos celulares com formas subesférica, hemisferóides e cuneiformes, com número de células normalmente igual a 2, 3, 4, 6 ou 8, são os caracteres que permitem atribuir os espécimes ao gênero Gloeodiniopsis Schopf, 1968, emend. Knoll \& Golubić, 1979.

A maioria das espécies classificadas neste táxon tem bainha espessa ou mesmo multilamelada (p.ex. Schopf, 1968; Knoll et al 1991; Sergeev 1994). Muitas são solitárias (p.ex. Knoll \& Golubić 1979, Sergeev 1994, Kumar \& Srivastava 1992). Gloeodiniopsis sp. 1 diferencia-se destas por não apresentar uma bainha conspícua. Kumar \& Srivastava (1992), (Proterozóico Médio a Superior - Índia) descreveram espécimes de Gloeodiniopsis gregaria Knoll \& Golubić, 1979, que, da mesma forma que Gloeodiniopsis sp. 1, têm bainha pouco evidente, células hemisferóides (consideradas pelos autores elipsóides) e 4 a 10 unidades por conjunto celular. Porém, os diâmetros celulares do material da Formação Assistência são muito maiores do que o material de Kumar \& Srivastava (1992), que tem diâmetro médio de $19 \mu \mathrm{m}$, variando entre 12 a $21 \mu \mathrm{m}$. Alem disso, G. gregaria não apresenta células subesférica e cuneiformes.

Gloeodiniopsis sp 1 apresenta semelhanças com alguns espécimes de Gloeodiniopsis lamellosa ilustrados por Sergeev (1994) (Mesoproterozoico - Rússia) no que diz respeito à variedade celular dentro das colônias e à bainha pouco evidente. Outros espécimes de $G$. lamellosa no material de Sergeev (1994), porém, possuem bainhas mais espessas ou multilameladas. 


\section{Espécie 2}

Figuras, 12, 18, 20, 21, 22, 23, 24 Tabelas 3, 4, 5 Seção 6.2

\section{$\underline{\text { Descrição }}$}

Colônias com aspecto delicado, compostas de células subesféricas, hemisferóides e cuneiformes, na maioria das vezes sobrepostas entre si, agregadas em conjuntos irregulares ou em pacotes. Número variável de células por colônia, podendo ser mais que 20. Células na mesma colônia podem apresentar grande variedade de tamanho e forma. Invólucro celular fino e transparente, e em muitos exemplares rugoso. Bainha celular ausente ou pouco evidente. Porém o espaço conspícuo entre indivíduos próximos pode ser indício da existência de bainha. Diâmetro máximo das células subesféricas de 9,0 a 21,8 $\mu \mathrm{m}$, com média de 14,9 $\mu \mathrm{m}(\mathrm{N}=27)$. Diâmetro máximo das células hemisferóides de 9,3 a 21,6 $\mu \mathrm{m}$, com média de 15,1 $\mu \mathrm{m}(\mathrm{N}=62)$. Diâmetro máximo das células cuneiformes de 6,4 a 32,8 $\mu \mathrm{m}$, com média de $14,7 \mu \mathrm{m}(\mathrm{N}=135)$.

Material: Localidades: Estrela e Paraisolândia 1. Camada das Dobras Enterolíticas, Níveis 13, 7. Lâminas: GP/L-G6 3, GP/L-G6 10, GP/L-G6 13, GP/L-G6 8, GP/L-G6 19, GP/L-G6 22, GP/L-G6 23.

\section{$\underline{\text { Discussão }}$}

A grande variação de dimensões celulares em uma única colônia e a presença de conjuntos irregulares ou em pacotes são bastante característicos do gênero moderno Cyanosarcina Kováćik (1988) (Cyanobacteria). Alem disso, as diferenças dos conjuntos celulares da Espécie 2, quando comparadas à descrição do padrão de divisão celular de Anagnostidis \& Komárek (1988) para Cyanosarcina (Figura19), tornam a analogia entre as morfologias da duas espécies ainda mais aceitável.

Reino: Plantae Haeckel, 1866

Filo: ChLorophyta Pascher, 1914

Classe: ChLOROPhyCEAe Kützing, 1943

Ordem: ChLoRococcales Pascher 1915

Família: ChLOROCOCCACEAE Blackman \& Tansley, 1902 


\section{Espécie 3}

Figuras 13, 18, 25 Tabelas 3, 4 Seção 6.3

\section{$\underline{\text { Descrição }}$}

Espécie unicelular e polimórfica, representada pelos Morfotipos D, E e F. Células relativamente grandes (diâmetros médios de 31,1 $\mu \mathrm{m}$, e 50,4 $\mu \mathrm{m}$, respectivamente), esféricas, geralmente solitárias, algumas agrupadas em conjuntos sem padrão geométrico. Morfotipo E tem uma região achatada e invólucro nítido. Bainha conspícua em Morfotipo D, inconspícua ou ausente em Morfotipo E e ausente em Morfotipo F. Morfotipo F apresenta um espécime com uma possível abertura.

Material: Localidades: Estrela e Paraisolândia 1, Camada de Dobras Enterolíticas. Níveis 1 e 2, Lâminas: GP/L-G6 17, GP/L-G6 18, GP/L-G6 19, GP/L-G6 21, GP/L-G6 22, GP/L-G6 23, GP/L-G6 3.

Morfotipo D (Figuras 13 a-f)

Células esféricas, solitárias. Bainha celular fina, conspícua, delimitada por superfícies opacas. Em alguns espécimes o limite interno da bainha é rugoso (Figuras 13 b e f). Diâmetro das células de 8,6 a 44,6 $\mu \mathrm{m}$ com média de 31,1 $\mu \mathrm{m}(\mathrm{N}=45)$. Espessura da bainha celular varia entre 0,8 e 3,9 $\mu \mathrm{m}$, com média de $2,1 \mu \mathrm{m}(\mathrm{N}=28)$.

\section{Morfotipo E (Figuras 13 g-i)}

Células esféricas com uma região achatada, a maioria em conjuntos sem padrão geométrico (Figuras 13 h-i), outras solitárias (Figuras 13 g). Parede fina. Um exemplar apresenta região externa mais translúcida, provavelmente uma bainha, com $2,2 \mu \mathrm{m}$ de espessura, mas que não engloba toda a célula (Figuras 13 j). Diâmetro das células de 11,9 a 48,3 $\mu \mathrm{m}$ com média de 24,0 $\mu \mathrm{m}(\mathrm{N}=8)$.

Morfotipo F (Figuras 13 k-1)

Células solitárias, esféricas, com invólucro espesso e opaco. Um dos espécimes apresenta abertura no invólucro. Somente duas células foram medidas, uma com diâmetro de 
50,8 $\mu \mathrm{m}$ (Figuras 13 k) e outro com 57,2 $\mu \mathrm{m}$ (Figuras 13 1) (média de 54,0 $\mu \mathrm{m}$ ). Espessura do invólucro 5,8 $\mu \mathrm{m}$ em um exemplar (Figuras $13 \mathrm{k}$ ) e $6,6 \mu \mathrm{m}$ no outro (Figuras 13) (média de 6,2 $\mu \mathrm{m}$ ).

\section{Discussão}

Como discutido na seção 6.3, os três morfotipos foram agrupados em um mesmo táxon porque os Morfotipos E e F ocorrem nas lâminas GP/L-6E 8 e GP/L-6E 23, juntamente com o Morfotipo D, e porque cada morfotipo se assemelha a uma fase da ontogênia da ordem de clorófitas Chlorococcales com aplanósporos (Lee 1980, Tappan 1980, Daugbjerg et al. 2000, Shubert 2003, Bicudo \& Menezes 2005) (Figura 26).

O Morfotipo D e o Morfotipo E têm muitas características semelhantes aos espécimes do conjunto de células classificado por Bernardi-Campesi et al. (2004) (Cretáceo - México) como Chlorella, embora esta últimas sejam menores (diâmetros que variam de 15-25 $\mu \mathrm{m})$ e ocorrem em grupo, também são unicelulares e esféricas, têm bainhas finas, conspícuas e entre finas superfícies opacas, que variam de 1 a $3 \mu \mathrm{m}$.

O Morfotipo D apresenta e invólucro semelhantes aos de Gloeodiniopsis lamellosa e Scissilisphaera gradata descritos por Green et al. (1989) (Proterozóico Superior Groelândia), que são constituídos por células esféricas com bainhas finas, conspícuas e entre finas superfícies opacas. Porem diferem do Morfotipo D porque ocorrem em grupo.

Mesmo assim, a Espécie 3 apresenta correspondências morfológicas a alguns táxons atuais. O Morfotipo D é muito parecido com cistos de Dunaliella. Estes últimos, apesar de comumente serem menores, são solitários e esféricos, têm bainha celular fina e conspícua. Porém Dunaliella não apresenta cistos com parede espessa (aplanósporos), e suas variantes flageladas são elipsóides, e não esferóides com o Morfotipo E.

Por outro lado, conforme reconstituição da Figura 26, muitos táxons da ordem Chlorococcales têm células vegetativas esféricas e solitárias, bem como variantes reprodutivas flageladas e formam aplanosporos (p. ex. Bracteacoccus, Dictyochloropsis, Chlorococcum). Já o gênero Neochloris, alem destas características, tem zoósporos biflagelados, que em situações de quiescência, são esferoidais (Shubert 2003). Como as possíveis células reprodutivas da Espécie 3 são esferóides (Morfotipo E), este parece ser o gênero moderno morfologicamente mais próximo à Espécie 3. 


\section{Incertae sedis}

\section{$\underline{\text { Morfotipo G }}$}

Figuras 14 e-f Tabelas 3, 4

Espécie-tipo: (Figuras 14 e)

\section{$\underline{\text { Descriç̧ão }}$}

Células esféricas, irregularmente sobrepostas, formando agregados cubóides, aparentemente com dois conjuntos de células adjacentes em si (Figuras 14 e). Parede celular espessa. Bainha ausente ou pouco evidente. Células envoltas por resíduos orgânicos em forma de grânulos. Células têm 15,2 $\mu \mathrm{m}$ de média de diâmetro máximo, que varia entre 14,5 e $17,1 \mu \mathrm{m}(\mathrm{N}=7)$.

Material: Localidade Estrela. Camada de Dobras Enterolíticas Nível 1-2, Lâminas: GP/LG6 21, GP/L-G6 17.

\section{Discussão}

A raridade deste táxon (apenas dois exemplares de colônias) e a peculiaridade do arranjo impossibilitaram qualquer inferência precisa quanto à afinidade biológica do Morfotipo G.

Glenobotrydion aenigmatis Schopf 1968, descrito originalmente do Neoproterozóico da Austrália, talvez seja o táxon morfologicamente mais parecido com o Morfotipo G, pois apresenta células esféricas, envoltas por resíduo orgânico granular, sem evidência de bainha. Porém, G. aenigmatis é um pouco menor (diâmetro médio de 9,0 $\mu \mathrm{m}$, variando entre 7,1 e $12,0 \mu \mathrm{m})$.

Schopf (1968) e Hofmann (1976) descreveram exemplares de Myxococcoides minor Schopf 1968 que também apresentam células esféricas envoltas por resíduos orgânicos granulares e parede celular espessa. Diferenciam-se do Morfotipo G porque muitos conjuntos de Myxococcoides minor podem ter maior número de células (aproximadamente 40). Os diâmetros celulares médios são ligeiramente menores, 13,5 $\mu \mathrm{m}$ em Schopf (1968), 
variando entre 8,8 e $10,5 \mu \mathrm{m}, \mathrm{N}=25$, e de $8,2 \mu \mathrm{m}$ em Hofmann (1976), variando entre 6,3 e $11,5 \mu \mathrm{m}, \mathrm{N}=12$.

Por fim, Knoll (1982) descreveram Myxococcoides cantabrigiensis que também consiste de células esféricas, com parede espessa e bem definida, ausência de bainha e algumas com resíduo orgânico intracelular granular. Porém é diferente do Morfotipo G pois inclui células solitárias, as colônias são menos empacotadas e o diâmetro médio das células é um pouco menor $(12,5 \mu \mathrm{m}$, variando entre 7 e $19 \mu \mathrm{m}, \mathrm{N}=447)$.

\section{Morfotipo H}

Figuras $14 \mathrm{~g}$ Tabelas 3, 4

\section{$\underline{\text { Descrição }}$}

Colônias de células irregularmente sobrepostas, aparentemente arranjadas em fileira. Células com bainha individual espessa, com superfície externa bem distinta. Parede celular nada ou pouco evidente. Ao redor das células há matéria orgânica amorfa de coloração marrom. Resíduo intracelular quase opaco, granular, com coloração de marrom a negra, fazendo com que as limites celulares sejam pouco nítidos. Por isso não foi possível mensurar os parâmetro morfométricos das células. Colônias variam entre 39,2 e 78,3 $\mu \mathrm{m}$ em diâmetro, com média de 54,9 $\mu \mathrm{m}(\mathrm{N}=6)$.

Material: Localidade Assistência, Camada de Ritmitos Superiores. Localidades Estrela e Paraisolândia 1, Camada de Dobras Enterolíticas, Níveis 2-3, 19. Lâminas:

GP/L-G6 60, GP/L-G6 3, GP/L-G6 22.

\section{Discussão}

As afinidades biológicas deste táxon são incertas porque, alem de ocorrer em baixo número (somente seis colônias), tem arranjo celular peculiar, tanto que nenhum equivalente morfológico atual ou fóssil foi encontrado até o presente momento. 


\section{Morfotipo I}

Descrição

Figuras 14 h-j Tabelas 3, 4

Espécimes constituídos somente por resíduos orgânicos irregularmente agregados, que lembram conjuntos de células subesféricas, hemisferóides, cuneiformes ou cilindricocurvadas, com coloração bege escura a negra. Diâmetro máximo das colônias entre 21,9 e 474,3 $\mu \mathrm{m}$, com média de $71,8 \mu \mathrm{m}(\mathrm{N}=34)$. Uma vez que as unidades celulares são demasiadamente degradadas, os diâmetros celulares não foram medidos.

Material: Localidades: Estrela e Paraisolândia 1, Soldeira Estrada - Camada das Dobras Enterolíticas, Nível 1-2. Lâminas: GP/L-G619, GP/L-G6 21, GP/L-G6 22, GP/L-G6 23, GP/L-G6 10, GP/L-G6 12, GP/L-G6 16, GP/L-G6 30.

\section{$\underline{\text { Discussão }}$}

O fato de que os agregados serem compostos por inúmeros conjuntos de resíduos intracelulares empacotados, que são encontrados onde a maior parte da microbiota fóssil da unidade está presente, levanta a hipótese de que o morfotipo possa ser variante tafonômica da Espécie 1, Gloeodiniopsis sp.1 ou da Espécie 2. Devido à ausência de caracteres de importância taxonômica, a afinidade biológica é incerta.

\section{Morfotipo J}

Figuras 14 k-1. Tabelas 3, 4

Descrição

Conjuntos de inúmeras células elipsóides, agrupadas aleatoriamente. Bainha celular espessa e descontínua. Limites celulares pouco nítidos. Resíduo intracelular negro, com aspecto granular. Uma vez que as unidades celulares demasiadamente degradadas, os diâmetros celulares não foram medidos.

Material: Localidade Estrela - Camada das Dobras Enterolíticas, Nível 1. Lâmina GP/L-G6 19. 


\section{$\underline{\text { Discussão }}$}

A bainha espessa e descontínua torna estes microfósseis bem distintos dos demais táxons da microbiota. Oehler et al. (1979) (Proterozóico Superior - Austrália) apresentam microfósseis não identificados com bainhas e resíduos intracelulares semelhantes. O fato das células estarem aparentemente murchas pode indicar afinidade biológica com cianobactérias, que não têm parede celular constituída de celulose (Knoll \& Golubić 1979). A ausência de mais caracteres de importância taxonômica não permite o estabelecimento de afinidade biológica mais precisa.

\section{Morfotipo K}

Figuras 14 m-n. Tabelas 3, 4

\section{$\underline{\text { Descrição }}$}

Colônia única composta de dezenas de células romboidais, comprimidas entre si em arranjo frambóide. Diâmetro da colônia 35 m.

Material: Localidade Paraisolândia 1 - Camada das Dobras Enterolíticas. Nivel 1. Lâmina GP/L-G6 2.

\section{Discussão}

Formas com arranjo frambóide semelhante são encontradas em alguns táxons modernos, como nas cianobactérias Cyanosarcina (Cyanophyta) (ver Komárek 2003) e Coelomoron (Komárek 2003) e na clorófita Astrephomene (Nozak 2003).

É possível também que o aspecto delicado das células da Espécie 2, que também tem invólucro transparente, seja indicativo de que o Morfotipo $\mathrm{K}$ represente uma fase da ontogenia desta espécie, ou que ambos apresentem o mesmo tido preservação.

Superfícies celulares quase totalmente transparentes é um caracter também encontrado em dúbiomicrofósseis da própria Formação Assistência, como na Figuras 2 c-d. Por isso, juntos podem constituir diferentes fases do desenvolvimento de um único táxon.

Como somente um exemplar foi encontrado, a afinidade deste táxon é incerta, bem como análises paleobiológicas mais profundas não são possíveis. 


\section{8 - DISCUSSÃO}

\section{1 - CONTRIBUIÇÃO DA UTILIZAÇÃO DE LÂMINAS DELGADAS AO ESTUDO DE MICROFÓSSEIS DA FORMAÇÃO ASSISTÊNCIA}

Em trabalhos visando zoneamento bioestratigráfico com microfósseis orgânicos (palinomorfos), é praxe utilizar resíduos orgânicos derivados de rochas siliciclásticas finas, isso porque muitos palinomorfos são bons fósseis-guia. Exemplos disso são os acritarcas em rochas marinhas e os grãos de pólen e esporos em rochas continentais. Este material também fornece valiosas informações paleobiológicas sobre o fitoplâncton e a vegetação terrestre adjacente ao sítio deposicional. No entanto, os resíduos orgânicos têm as limitações de (i) serem misturas de matéria orgânica derivada de todas as diversas lâminas ou camadas presentes na amostra de rocha dissolvida; e (ii) de conterem assembléias fósseis quase que exclusivamente de microfósseis resistentes aos processos tafonômicos e ao agressivo ataque químico que os liberou da rocha. Por isso, a avaliação tafonômica e ontogênica de seus constituintes fica comprometida, e qualquer abordagem paleoecológica do material se torna muito limitada.

Por outro lado, o exame petrográfico de microorganismos fósseis em lâminas delgadas de sílex pode revelar (i) a forma tridimensional das células dos microorganismos presentes; (ii) a distribuição dos microfósseis in situ na rocha, (iii) as disposições dos microfósseis entre si e (iv) com outros elementos petrográficos, como textura, petrotrama, mineralogia, laminação e feições secundárias (fraturas, compactação, alteração intempérica, etc.) (Figura $15 \mathrm{~b})$.

As lâminas delgadas trazem à luz justamente os tipos de feições raramente presentes em exame de resíduos orgânicos, esclarecendo, por exemplo, aspectos da paleoecologia e os processos de deposição e fossilização. Mas talvez a diferença mais significativa entre os dois materiais seja o fato de que as lâminas petrográficas permitem a observação de microestruturas orgânicas delicadas, dificilmente presentes em preparações palinológicas, como, por exemplo, resquícios de material intracelular, células vegetativas, bainhas mucopeptídicas e outros (Figura 26).

Os protocolos de estudo de folhelhos (ataque químico) e de sílex (exame petrográfico) apresentam, portanto, resultados distintos, mas que se complementam. Assembléias de microfósseis em resíduos extraídos de folhelhos são compostos principalmente por palinomorfos planctônicos e/ou esporos e pólen de plantas terrestres 
transportados pelo vento ou correntes de água, enquanto os microorganismos permineralizados em sílex comumente incluem restos de microbiotas bentônicas, especialmente quando associados a microbialitos (esteiras micobianas, oncóides ou estromatólitos), podendo incluir também elementos planctônicos parautóctones (acritarcas e microalgas), ou alóctones (esporos, grãos de pólen, fitoclastos). Nesses casos, mesmo que sejam raros, o estudo petrográfico do sílex microfossilífero oferece grande potencial para complementar pesquisas palinológicas tradicionais, especialmente no que diz respeito à morfologia tridimensional dos palinomorfos, alem de assinaturas tafonômicas, abundância e distribuição estratigráfica de detalhes.

Por isso a escolha de um destes métodos de análise depende da abordagem da pesquisa. Ambos são úteis em trabalhos com taxonomia de palinomorfos. Já para pesquisas bioestratigráficas, os resíduos orgânicos são mais indicados, pois geralmente concentram maiores quantidades de fósseis-guia. Por outro lado, para estudos paleobiológicos e paleoecológicos de microorganismos bentônicos preservados por permineralização em sílex (ou outras substâncias como fosfato, calcita ou pirita), recomenda-se o exame de lâminas delgadas.

A aplicação de lâminas delgadas na Formação Assistência revelou um conteúdo paleobiológico ausentes nas preparações palinológicas observadas anteriormente, permitindo:

- Trazer a luz a existência de sua microbiota fóssil com seus 10 táxons descritos (4 de cianobacterias interpretadas como bentônicas, 1 de um clorófita e 5 incertae sedis), mas também:

- Revelar que esta microbiota possui distribuição geográfica relativamente ampla;

- Observação dos palinomorfos em 3 dimensões, o que será ferramenta para melhor entender sua a morfologia.

- Revelar que há microfósseis, nas 9 localidades estudadas, nos 21 níveis com sílex diageneticamente precoce.

- Inferir que a co-ocorrência dos morfotipos A, B e C indica que os três devem ser variantes tafonômicas de uma única espécie

- Inferir processos diagenéticos e o padrão de divisão celular e reprodução de alguns táxons, o que auxiliou nas inferências taxonômicas e tafonômicas. 

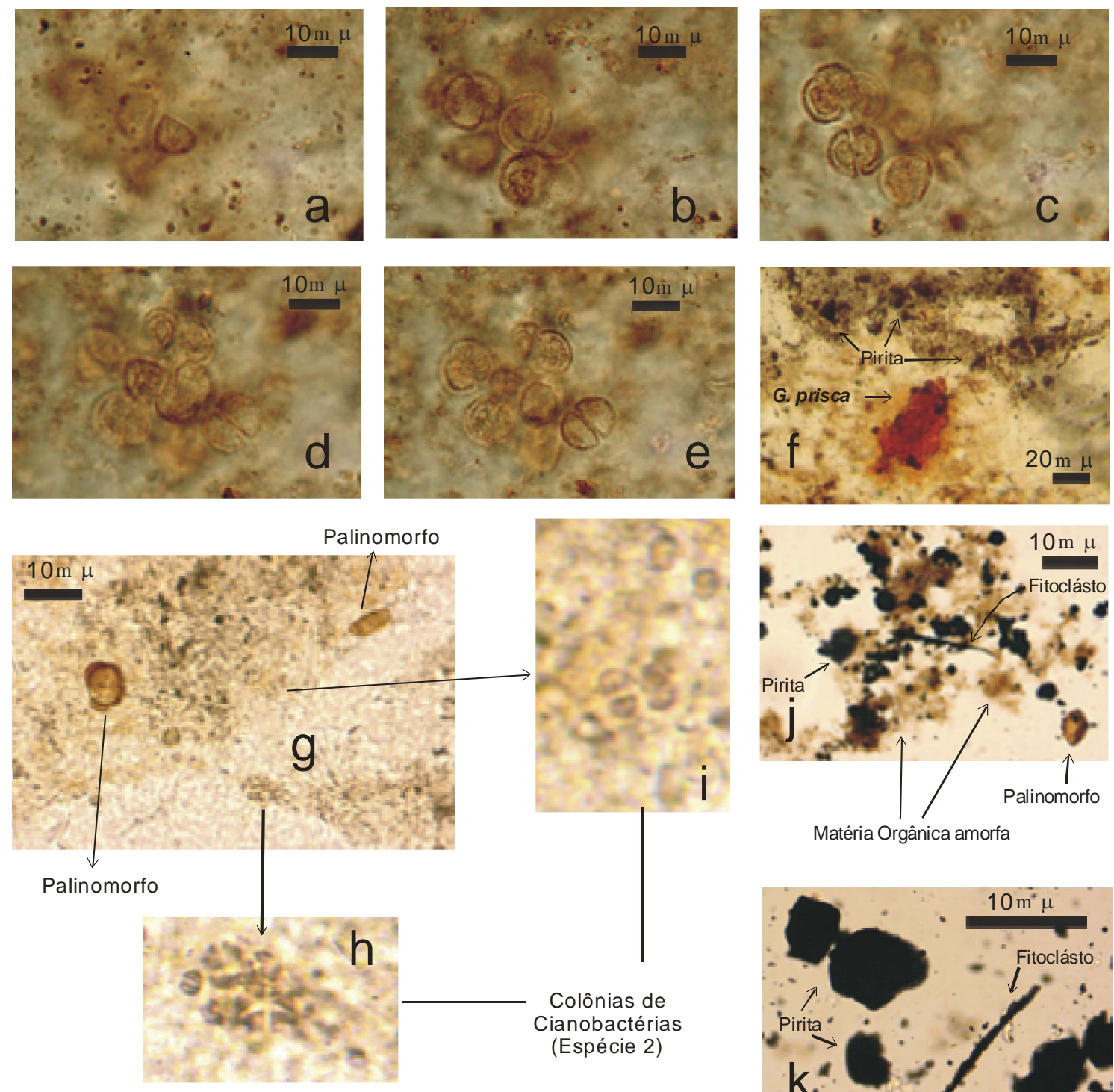

Matéria Orgânica amorfa

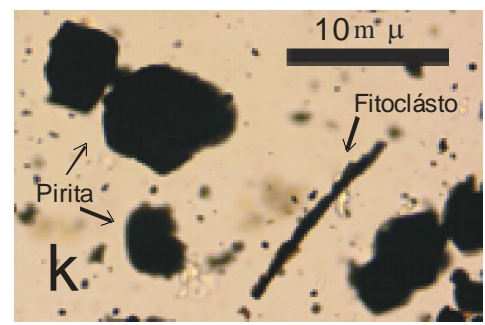

Figura 26: Imagens de microscopia petrográfica de sílex negro da Formação Assistência. Aspecto marrom da maior parte da área é decorrente da matéria orgânica amorfa, todas da localidade Paraisolândia 1 .(a-i): imagens de lâminas delgadas, nas quais as microestruturas encontram-se in situ, permitindo a observação de materiais mais frágeis. (j-k): imagens obtidas de resíduos orgânicos, ilustrando as microestruturas resistentes ao tratamento químico, como fitoclástos, grãos de pólen e pirita. Lâminas temporárias. (a-e): Diferentes níveis ópticos de uma mesma colônia, imagens que permitem a reconstituição do padrão de divisão celular da espécie. Lâmina GP/L-6E 4. (f): espécime de Morfotipo A e grãos de pirita, envoltas com matéria orgânica amorfa. Lâmina GP/L-6E 16. (g-i): dois palinomorfos (grãos de pólen bissacados de gimnospermas, em diferentes vistas) e colônias de cianobactérias. Lâmina GP/L-6E 3 (h-i): Detalhe das colônias de cianobactérias.

\subsection{Processo de silicificação}

\subsection{1 - Cronologia da litificação}

Há diversos indícios de que a microbiota fóssil da Formação Assistência foi permineralizada por sílica em um estágio muito precoce de diagênese. É relativamente 
comum que lâminas da porção carbonática tenham maior compactação em torno dos nódulos e lentes de sílex (Figura 7), evidenciando que o nódulo foi litificado antes do sedimento encaixante. A própria preservação tridimensional, somente no sílex, de microorganismos, compostos por material orgânico muito delicado, como celulose e mucopolipepitídios, em grande quantidade e com detalhes morfológicos (Figuras 10 - 15) é forte indício de que a permineralização ocorreu muito cedo, antes mesmo que agentes físicoquímicos e microbianos pudessem afetar significativamente a estrutura e os componentes da comunidade microbiana original.

Golubić (1976) sugeriu que a escala de tempo na qual microorganismos podem permanecer com morfologias pouco alteradas na registro litológico pode ser comparada ao exemplo de uma turfa microbiana nos sedimentos do sabkha de Abu Dhabi (Golfo Pérsico), com tem aproximadamente 8000 anos, que ainda conserva parcialmente a pigmentação e estruturas celulares dos componentes de esteiras microbianas soterradas a poucas dezenas de centímetros da superfície.

Bartley (1996) demonstrou que, devido à rápida degradação de microorganismos mortos, a silicificação precoce pode preservar, simultaneamente, indivíduos em diferentes estágios tafonômicos. A microbiota da Formação Assistência exemplifica este fenômeno, pois nela há tanto células fósseis com invólucros muito semelhantes a superfícies de microorganismos vivos, quanto microorganismo fósseis com morfologias bastante alteradas (p.ex. Figuras 10 - 15). Tais microorganismos são encontrados muitas vezes no mesmo nível estratigráfico e, não menos comum, na mesma lâmina delgada.

\subsection{2 - Origem da sílica}

A sílica em sílex pode ter origem biológica ou química. No primeiro caso, a remobilização de sílica biogênica gera depósitos silicosos secundários, o que pode ser inferido pela presença de fósseis silicosos na pilha sedimentar (Riech \& $\operatorname{Rad} 1979$, Greensmith 1989, Hesse 1990a, b). Com relação ao Subgrupo Iratí, Amaral (1971) sugeriu que a fonte da sílica pudesse ser espículas silicosas de esponjas, e Eilert (2001) aventou a presença de radiolários, outro microfóssil silicoso, nesta unidade. Porém, em ambos casos, nunca houve re-estudo ou confirmação destas afirmações, o que sugere que esponjas e radiolários deveriam ter sido, no máximo, muito raros na época, a ponto de não conterem sílica suficiente para formar o grande volume de sílex conhecido na unidade (Yamamoto et al. 2004). 
Nas lâminas delgadas da Camada de Dobras Enterolíticas os microorganismos fósseis comumente ocorrem em massas tão volumosas que devem ter constituído parte significativa do arcabouço sedimentar, deixando pouco espaço para sedimento carbonático ou siliciclástico. Geralmente, estão preservados em sílica criptocristalina, sob a forma de cristais equidimensionais, extremamente pequenos, que apresentam um aspecto "sal-epimenta" quando observados com nicóis cruzados. Fenestras (espaços abertos no sedimento original) apresentam preenchimento de calcedônia fibrosa nas bordas e microquartzo no centro.

Muitas destas feições ocorrem também em praticamente todas as mais importantes unidades com microorganismos fósseis silicificados do Proterozóico (p. ex. Schopf, 1968; Schopf \& Blacic, 1971; Barghoorn et al.; 1977; Hofmann, 1976; Knoll \& Golubić, 1979). Há indícios de que os modos de silicificação mudaram significativamente desde o Proterozóico até os dias de hoje, graças à irradiação, no Fanerozóico, dos organismos capazes de secretar sílica. É mais comum no Fanerozóico o predomínio de sílex diageneticamente tardio, derivado de sílica biogênica (Maliva et al. 1989; Kidder \& Erwin 2001). Assim, o sílex da Formação Assistência foge a este padrão, se assemelhando mais às ocorrências de sílex microfossilífero, diageneticamente precoce, do Pré-Cambriano.

Yamamoto et al. (2004) argumentam que a sílica do Subgrupo Iratí poderia ter se originado a partir da alteração de argilominerais provocada pela alternância cíclica entre climas fortemente úmidos e secos. O caráter marcadamente rítmico (folhelho/calcário) da Formação Assistência (Hachiro 1993), fortalece esta interpretação.

Há uma outra possibilidade sugerida pela recente percepção da presença significativa e importância geocronológica de finas camadas de cinzas vulcânicas na Bacia do Paraná. Coutinho \& Hachiro (2005) descreveram 23 ocorrências deste material em rochas permianas da bacia, e Santos et al. (2006) analisaram cristais de zircão em três níveis de cinzas nos folhelhos pirobetuminosos do Subgrupo Irati na região de São Mateus do Sul, PR. Evidentemente, cinzas vulcânicas também devem ter alcançado o Estado de São Paulo durante a deposição da Formação Assistência. Nas águas mais rasas e aparentemente mais alcalinas do estado de São Paulo, as cinzas vitroclásticas seriam mais facilmente dissolvidas do que nas águas mais profundas de São Mateus do Sul. Assim, as águas intersticiais dos sedimentos da época poderiam ter ficado supersaturadas em sílica. Ao entrar em contato com o microambiente mais ácido gerado em torno de matéria orgânica (esteiras e massas microbianas) nos estágios iniciais de degradação, a sílica em solução se precipitaria como sílica amorfa, preservando os microfósseis em grande detalhe (Iler 1979). Com o tempo, a 
sílica amorfa se transformaria em calcedônia e quartzo. Uma vez que os paleoambientes mais ao norte da bacia eram mais rasos, muitos deles deveriam ser restritos, com formação de evaporitos (Faure \& Cole 1999). Assim, a salinidade alta aceleraria a silicificação (Iler 1979).

\section{3 - Distribuição estratigráfica da microbiota fóssil}

Embora fossem detectados microfósseis em lâminas de sílex de 21 níveis diferentes, representando todas as camadas da Formação Assistência, menos o Laje Azul, e diversas localidades no Estado de São Paulo, a microbiota da Formação Assistência, objeto de estudo do presente trabalho, foi encontrada principalmente na localidade Paraisolândia 1, Estrela e Soldeira Estrada, e está altamente concentrada na Camada de Dobras Enterolíticas (Figura 2, Tabela 1), unidade basal da formação.

Este nível é composto por folhelhos escuros, carbonato e sílex, comumente em camadas convolutas. Tanto na região de Fartura, como na localidade de Paraisolândia 1, o sílex negro está associado a estas camadas perturbadas, principalmente às partes antiformes, onde forma grandes massas de dimensões decimétricas (Figuras 3-4).

Segundo Hachiro (1997), o aspecto convoluto destas rochas seria consequiência da precipitação de uma camada de mineral evaporítico (anidrita ou gipsita). Esta camada pode ter se formado ou na interface água/sedimento ou a partir de água intersticial dentro dos sedimentos ainda inconsolidados. No primeiro caso, a camada evaporítica, uma vez soterrada de baixo de sedimentos mais densos, poderia ter iniciado um fluxo diapírico que teria deformado os sedimentos sobrejacentes. No segundo caso, a precipitação de sais, teria levado à formação de uma camada de evaporitos, inicialmente em múltiplos pontos no mesmo nível dentro dos sedimentos. A medida em que esta camada aumentava, a força de cristalização dos minerais dentro dos sedimentos inconsolidados teria distorcido a própria camada até parecer as dobras intestinais, dando origem ao termo "dobras enterolíticas" para esta feição.

Para Riccomini (1992), no entanto, estas perturbações foram causadas por tectonismo sindeposicional, pois interpreta a orientação das dobras na região do Alto Estrutural de Pitanga como uniforme. Evidentemente, é possível que as duas interpretações sejam possíveis, pois nada impediria que camadas deformadas por evaporitos possam também ter sido deformadas por tectônismo sindeposicional. 
De qualquer maneira, os dois autores reconhecem que o dobramento ocorreu penecontemporaneamente em relação à deposição. Dada as diferenças gritantes na competência reológica entre evaporitos (ou calcários) por um lado, e sílex, pelo outro. É bastante provável que o dobramento também tenha antecedido a silicificação das camadas e a permineralização da microbiota bentônica descrita aqui. Dessa forma, o dobramento também teria ocorrido extremamente cedo na história geológica da camada.

A concentração da microbiota na camada basal da Formação Assistência levanta duas hipóteses: (i) houve maior produção de biomassa ficológica e/ou diversidade de microorganismos no início da deposição da formação ou (ii) os fatores sedimentológicos e tafonômicos eram mais propícios para preservação na camada basal do que nas camadas superiores.

Os vestígios de atividade biológica ao longo de toda a formação, como a presença de biomarcadores orgânicos (p. ex. Faure \& Cole 1999), fósseis microscópicos (p. ex. Amaral 1971) e fósseis macroscópicos (p. ex. Mussa 1982; Fairchild et al. 1985; Oelofsen \& Araújo 1987), desfavorecem a primeira hipótese, demonstrando que o cenário paleoecológico não deveria ter sido substancialmente menos complexo nos demais níveis da unidade.

Já a segunda hipótese é fortalecida pelo acamamento convoluto desta camada, que a destaca em relação às demais. Como discutido acima, esta feição pode ter origem devido a formação de evaporitos. Se o paleoambiente foi mesmo hipersalino, seus sedimentos provavelmente devem ter sido depositados em condições mais marginais que as demais da formação. Este cenário ajuda a compreender porque os microorganismos fósseis são tão abundantes e bem preservados nesta camada. Microorganismos adaptados a ambientes hipersalinos são naturalmente mais resistentes à dessecação, o que aumenta seu potencial de preservação (ver Knoll \& Barghoorn 1977; Francis et al 1978; Knoll \& Golubić 1979). Nessas condições, colônias e comunidades de microorganismos poderiam ser englobadas pela rápida precipitação de minerais evaporíticos (Knoll \& Golubić 1979). Ou águas intersticiais, com salinidade muito alta, podem retardar a degradação microbiana dos microorganismos e favorecer a permineralização precoce (Iler 1979). 


\section{4 - Hábito e habitat da microbiota}

Dada à importância e abundância de microfósseis filamentosos nas microbiotas preservadas em sílex, talvez a feição mais descomunal na Formação Irati seja a exclusividade de microrganismos unicelulares. Como regra geral, assembléias de microorganismos fósseis são compostas tanto por formas filamentosas quanto por organismos unicelulares, como nas formações Gunflint (Barghoorn \& Tyler 1965) Bitter Springs (Schopf 1968; Knoll \& Golubić; 1979) e do grupo Paranoá (Fairchild et al. 1996).

Alem disso, são raras as comunidades atuais onde todas as microalgas e cianobactérias são unicelulares. Um dos poucos ambientes onde isso ocorre são desertos onde cianobactérias endolíticas penetram em arenitos e, mais raramente, evaporitos (Rothschild et al. 1994). Friedmann (1982) menciona que somente líquens e organismos unicelulares podem penetrar poros estreitos em rochas. Bhatnagar \& Bhatnagar (2005) e Komárek (2003) comentam que estas comunidades são compostas quase totalmente por cianobactérias unicelulares dos gêneros Chroococcidiopsis e Gloeocapsa.

Outro exemplo atual ocorre em eflorescências microbianas, quando uma população de microorganismos aquáticos de baixa diversidade (quase sempre uma única espécie) produz uma elevada biomassa (Wehr \& Sheath 2003; Estrada et al. 2004). Ambientes estressantes favorecem este processo (Estrada et al. 2004), como águas eutrofizadas de baixa turbulência (Komárek 2003; Zohary \& Breen 1989).

Finalmente, alta salinidade também pode ser responsável pela exclusividade de formas unicelulares. Embora não haja muitos exemplos modernos de ambientes hipersalinos com microbiotas sem filamentos, é verdade que as formas unicelulares predominam em muitos corpos d'água com altas concentrações de sal. Ulukanli \& Diğrak (2002) demonstraram o predomínio de espécies unicelulares dos gêneros cianobacterianos Chroococcus, Synechococcus e Synechocystis no lago hipersalino como Lake Magadi, (Quênia). Bauld (1981) cita a dominância de cianobactérias unicelulares nos sistemas salinos de South Bonaire (Caribe), de Dry Creek e Port Alma, na Austrália, e de Long Island, nas Bahamas. Rothschild et al. (1994) encontraram somente microorganismos unicelulares em comunidade endoevaporítica na Laguna Guerrero Negro, na costa pacífica da Baja Califórnia, no México.

Não há nenhuma evidência de que a microbiota da Formação Assistência teria sido endolítica, penetrando sedimentos já litificados num ambiente desértico. De fato, os dados sedimentológicos apontam para um ambiente aquoso, não desértico. Mesmo com as fortes 
evidências de evaporitos na camada basal, nenhum dos microorganismos observados exibe hábito endoevaporítico, pois não há feições que pudessem ser interpretadas com fraturas ou poros preexistentes, e nenhuma prova de que os microorganismos tivessem incrustado ou penetrado em superfícies. Alem disso, as colônias de microorganismos comumente constituem massas volumosas e compactas que apontam para um modo de vida bentônico fotossintetizante, na forma de biofilmes ou esteiras soterradas in situ.

Já a possibilidade de eflorescências microbianas encontra indícios favoráveis. A aparente riqueza original da assembléia de microorganismos é coerente com esta proposta. A grande quantidade de hidrocarbonetos de origem microbiana (betúmem, pirobetúmem e querogêneo) presente ao longo de toda a Formação Assistência (Amaral 1971; Silvia \& Cornford 1985; Faure \& Cole 1999) indica que houve grande produção de biomassa ficológica na unidade. Faure \& Cole (1999) atribuem isto a repetidas eflorescências de Botryococcus brauni. Segundo os autores, o fracionamento isotópico entre $\mathrm{o}_{\mathrm{CO}_{2}} \mathrm{em}$ folhelhos de unidades permianas do supercontinente Gondvana indica ocorrência de eflorescências de microorganismos análogos a Entophysalis atuais. A presença de pirita nos diversos níveis do Subgrupo Irati é indicio de condições de fundo freqüentemente redutores, possivelmente associadas à condições eutróficas, o que favorece a hipótese de eflorescências.

Contudo, mesmo que a produção de grande biomassa ficológica no Subgrupo Irati tenha sido demonstrada por Faure \& Cole (1999), os autores exploraram folhelhos do município de São Mateus do Sul, que fica ao sul do Arco de Ponta Grossa, onde o paleoambiente do Subgrupo Irati é representado por corpos d'água mais profundos. Assim, a microbiota do presente trabalho não deve ter participado destas eflorescências. Alem disso, a raridade de microorganismos fóssil nos demais níveis da formação leva à conclusão de que o processo de eflorescência não deve ter sido o responsável pela exclusividade de formas unicelulares, uma vez que a matéria orgânica amorfa e os hidrocarbonetos de origem microbiana não estão concentrados na Camada de Dobras Enterolíticas, enquanto a microbiota fóssil está (Tabela 3). Por fim, A diversidade taxonômica relativamente alta da microbiota fóssil da Formação Assistência, demonstrada no presente trabalho, deve ser maior que a encontrada em eflorescências.

O modelo de ambiente hipersalino parece ser o mais coerente com as evidências disponíveis. A presença da microbiota em estromatólitos na camada basal da Formação Assistência (Figura 16, ver também Fairchild et al. 1985) fortalece a idéia de um ambiente deposicional aquoso hipersalino, que seria portanto inóspito a maioria dos seres vivos, com 
exceção de muitas comunidades microbianas fotossintetizantes (Walter 1976). Segundo Silva et al. (2004), microorganismos unicelulares formadores de estromatólitos modernos, em geral, são mais tolerantes às altas salinidades do que formas filamentosas. Bauld (1981), Oren (2000) e Ulukanli \& Diğrak (2002) citam a dominância de cianobactérias unicelulares em esteiras microbianas de salinas atuais. Aparentemente, a razão deste predomínio está na maior velocidade, em comparação aos microorganismos filamentosos, de resposta metabólica destes organismos face às mudanças ambientais (Borowitzka 1981; Friedmann 1982; Thomas et al 2005).

Algumas feições de outras microbiotas fósseis, embora não totalmente análogas, apresentam importantes similaridades com a assembléia microbiana da Formação Assistência: Horodyski \& Donaldson (1983) relataram a maior abundância de microfósseis de cianobactérias unicelulares em ambientes deposicionais interpretados como hipersalinos no Grupo Dismal Lakes (Mesoproterozóico do Canadá); Knoll \& Golubić (1979) aventaram que algumas concentrações de microorganismos unicelulares na Formação Bitter Springs (Neoproterozóico da Austrália) representariam comunidades adaptadas a poços pequenos, onde a salinidade variaria constantemente graças à evaporação da água.

Deduz-se assim que o modelo de ambiente hipersalino com variação de salinidade seja o que melhor explique a exclusividade de microfósseis unicelulares. Como neste tipo de ambiente não é possível se produzir grande quantidade de biomassa sem um aporte de água, a hipótese de ambiente hipersalino e eflorescência são mutuamente excludentes (L. J. Rothschild, comunicado pessoal, 2006). Por tudo isso, conclui-se que a microbiota preservada na Camada de Dobras Enterolíticas não representa eflorescências, mas sim uma comunidade bentônica que viveu em um corpo d'água raso e hipersalino.

\section{9 - CONCLUSÕES}

O trabalho apresentado aqui demonstrou a utilidade do uso de lâminas delgadas em estudos micropaleontológicos de sílex diageneticamente precoce na Formação Assistência (Neopermiano da Bacia do Paraná). Esta técnica tem a vantagem de permitir a observação de microorganismos fósseis delicados, bem como palinomorfos, todos em três dimensões, exatamente como foram preservados. No caso da microbiota fóssil aqui descrita, as lâminas delgadas revelam relações tafonômicas, ontogênicas e paleoecológicas impossíveis de observar em estudos palinológicos de resíduos orgânicos. Desta maneira, esta técnica 
complementa os estudos palinológicos tradicionais e oferece oportunidades de observar detalhes estruturais e de ornamentação de palinomorfos, que em resíduos orgânicos palinológicos praticamente sempre consistem de compressões bidimensionais.

A escolha entre a utilização de lâminas delgadas ou de resíduos orgânicos depende dos materiais disponíveis (rochas terrígenas finas vs. sílex) e do propósito da pesquisa. Tanto uma como outra poderão ser úteis em trabalhos de taxonomia de palinomorfos. Já para estudos bioestratigráficas, os resíduos orgânicos são mais indicados, pois permitem exame de um volume maior de rocha. Para trabalhos com fins paleobiológicos, paleoecológicos e tafonômicos de tafofloras microbianas fósseis, preservadas in situ, recomenda-se a observação em lâminas delgadas.

A aplicação de lâminas delgadas no estudo micropaleontológico do sílex da Formação Assistência, procedimento até agora inédito, revelou aspectos paleobiológicos desconhecidos desta formação, principalmente a presença de uma microbiota fóssil abundante e volumosa na base da formação e os palinomorfos preservados tridimensionalmente em todos os níveis examinados, alem de proporcionar seguintes observações e conclusões:

i. A co-ocorrência dos morfotipos A, B e C, considerados como variantes tafonômicas de uma única espécie biológica;

ii. Os padrões de divisão celular e reprodução de alguns táxons, que auxiliou na diferenciação entre Gloeodiniopsis sp. 1 e Espécie 2 e na atribuição, em alguns táxons, de possíveis afinidades com as cianobactérias e clorofíceas;

iii. A exclusividade de microorganismos unicelulares, ora solitários, ora coloniais, sem nenhum vestígio de filamentos.

Por fim, dessas e outras observações apresentadas nesta dissertação, pode-se concluir também que:

i. Os microfósseis delicados na Camada de Dobras Enterolíticas, na base da Formação Assistência, ocorrem como massas volumosas e densas de microorganismos fotossintetizantes bentônicos preservados in situ, capazes de formar esteiras microbianas e construir pequenos estromatólitos.

ii. Mesmo que esta microbiota seja formada apenas por organismos unicelulares, tem variedade morfológica relativamente grande. Novos táxons poderão ser revelados futuramente.

iii. Características como ampla extensão geográfica, hábito, abundância e caráter exclusivamente unicelular dos microorganismos fósseis, aliadas às interpretações 
sedimentológicas e às inferências paleoambientais implícitas nas semelhanças morfológica da microbiota fóssil com outras atuais análogas, são coerentes com interpretação de que habitat desta comunidade foi aquoso raso de salinidade alta, talvez com variação de salinidade.

iv. A exclusividade de formas unicelulares na microbiota é um fenômeno original e não causado por processos tafonômico, e é interpretado como decorrente da hipersalinidade do paleoambiente.

v. A microbiota fóssil foi permineralizada por sílica num estágio muito precoce da diagênese, antes da degradação significativa dos microorganismos, antes da compactação dos sedimentos, mas depois da deformação que formou as "dobras enterolíticas" da camada basal da formação.

\section{BIBLIOGRAFIA}

ALVES, L. S. R. 2001. Lenhos fósseis das Formações Irati e Serra Alta (Permiano Superior), São Paulo e Rio Grande do Sul: Considerações estratigráficas e inferências paleoclimáticas. In: Correlação de Seqüências Paleozóicas Sul-americanas. Petróleo Brasileiro S/A, PETROBRAS, Brasil. 203-208.

AMARAL, S. E. 1971. Geologia e petrologia da Formação Iratí (Permiano) no Estado de São Paulo. Boletim IGA, 2: 8 - 81 .

AMENÁBAR, R. C.; OTTONE, E. G. 2003. La aplicación de Botryococcus (Chlorococcales) como indicador paleoambiental en el Triásico de Argentina. Revista Española de Micropaleontología. 35: 25-35.

ANAGNOSTIDIS, K.; KOMÁREK, J. 1988. Modern approach to the classification system of cyanophytes. 2. Chlroococcales. Hydrobiologie Algological Studies. 43: 157-226.

BARGHOORN, E. S.; KNOLL, A. H.; DEMBICKI, H.; MEINSCHEIN, W. G. 1977. Variation in stable carbon isotopes in organic matter from the Gunflint Iron Formation. Geochimica et Cosmochimica Acta. 41: 425-430.

BARGHOORN, E. S.; TYLER, S. A. 1965. Microorganisms from the Gunflint chert. Science. 147: 563-577.

BARTLEY, J. K. 1996. Actualistic taphonomy of cyanobacteria: Implications for the Precambrian fossil record. Palaios. 11: 571-586. 
BAULD, J. 1981. Occurrence of benthic microbial mats in saline lakes. Hydrobiologia. 81: 87-111.

BERKALOFF, C. E.; CASADEVALL, C.; LARGEAU, C.; PERACCA M. S.; VIRLET J. 1983. The resistant polymer of the walls of the hydrocarbon-rich alga Botryococcus braunii. Phytochemistry. 22: 389-397.

BERKalofF, C.; ROUSSEAU, B.; COUTÉ, A.; CASADEVAll, E.; METZGER, P. CHIRAC, C. 1984. Variability of cell wall structure and hydrocarbon type in different strains of Botryococcus braunii. Journal of Phycology. 10: 377-389.

BERNARDI-CAMPESI， H.; CEVALLOS-FERRIZ， S. R. S. 2005. Diversidad de microfósiles en la Formación Tarahumara, Sonora. Revista Mexicana de Ciencias Geológicas. 22: 261-271.

BERNARDI-CAMPESI, H.; CEVALLOS-FERRIZ, S.R.S.; CHACÓN-BACA, E. 2004. Microfossil algae associated with Cretaceous stromatolites in the Tahahumara Formation, Sonora, México. Cretaceous Research. 25: 249-265.

BHATNAGAR, A.; BHATNAGAR, M. 2005. Microbial diversity in desert ecosystems. Current Science. 89: 91-100.

BICUDO, C. E. M.; MENEZES, M. 2005. Gêneros de Algas de Águas Continentais do Brasil, Chave de Identificação e Descrições. Ed. RiMa. São Carlos. 489 pp.

BLOKKER, P.; BERGEN, P. V.; PANCOST, R.; COLLINSON, M. E.; LEEUW, J. W.; DAMSTÉ, J. S. S. 2001. The chemical structure of Gloeocapsomorpha prisca microfossils: Implications for their origin. Geochimica et Cosmochimica Acta. 65: 885900.

BOROWITZA, L. J. 1981. The microbiota, adaptations to life in extremely saline lakes. Hydrobiologia. 81: 34-46.

BURJACK, M. I. A. 1984. Caracterização da matéria orgânica dispersa na Formação Assistência, Permiano Superior da Bacia do Paraná. Programa de Pós-graduação em Geociências, Universidade Federal do Rio Grande do Sul, Tese de Doutorado. 231 p. Inédita.

BURNS, D. J. 1982. A transmission electron microscope comparison of modern Botryococcus braunii with some microfossils previously referred to that species. Revista Española de Micropaleontologia. 14: 165-188.

BUTTERFIELD, N. J.; CHANDLER, F. W. 1992. Paleoenvironmental distribution of Proterozoic microfossils, with an example from the Agu Bay Formation, Baffin Island. Palaeontology. 35: 943-957. 
CALÇA, C. P.; FAIRCHILD. T. R. 2005. Uso de lâminas delgadas no estudo da microbiota fóssil da Formação Assistência (Subgrupo Irati, Permiano), Estado de São Paulo. Resumo: XIX Congresso Brasileiro de Paleontologia e VI Congresso Latino-Americano de Paleontologia. Aracajú. Meio digital.

CLOUD, P., MORRISON, K. 1979. On the microbial constaminants, micropsardofossils, and the oldest records of life. Precambrian Research. 9 (1/2): 81-91.

COUTINHO, J. M. V.; HACHIRO, J. 2005. Distribution, mineralogy, petrography, provenance and significance of Permian ash-carrying deposits in the Paraná Basin. Revista do Instituto de Geociências USP - Geologia USP, Série Científica. 9: 29-36p.

DAEMON, R.F.; QUADROS, L. P. 1970. Bioestratigrafia do Neopaleozóico da Bacia do Paraná. Anais do Congresso Brasileiro de Geologia. Brasília. 34: 355-412.

DASSARMA, S.; ARORA, P. 2001. Halophiles. Encyclopedia of Life Sciences. Secondary article. Wiley, Manhattan Press: http://els.wialey.com: 1-9.

DAVIS, J. S. 2001. Structure, function, and management of the biological system for seasonal solar saltworks. Global Nest: The International Journal. 2: 217-226.

DELLAZZANA, J. G. 1976. Contribuição à palinologia da Formação Irati (Permiano) Rio Grande do Sul, Brasil. Revista de la Asociación Paleontológica Argentina. 8: 1-42.

DERENNE, S.; METZGER, C.; LARGEAU, C.; VAN BERGEN, P. F.; GATELLIER, J. P.; DAMSTÉ, J. S. S.; LEEUW, J. W.; BERKALOFF, C. 1992. Similar morphological and chemical variations of Gloeocapsomorpha prisca in Ordovician sediments and cultured Botryococcus braunii as a response to changes in salinity. Organic Geochemistry 19: 299-312.

EILERT, V. P. 2001. Past and current radiolarian investigation in Brazil. Radiolaria: Newsletter of International Association of Radiolarian Paleontologists. 19: 5-5.

ESTRADA, M.; HENRIZSEN, P.; GASOL, J. M.; CASAMAYOR, E. O.; PEDRÓS-ALIÓ, C. 2004. Diversity of planktonic photoautotrophic microorganisms along a salinity gradient as depicted by microscopy, flow cytometry, pigment analysis and DNA-based methods. FEMS Microbiology Ecology. 49: 281-293.

FAIRCHILD, T.R.; 1983. Size criterion for distinguishing probable eukaryotic unicells in silicified Precambrian microbiotas. In: VIII Congresso Brasileiro de Paleontologia. Rio de Janeiro. 27: 315-320.

FAIRCHILD, T. R.; COIMBRA, A. M.; BOGGIANI, P. C. 1985. Ocorrência de estromatólitos silicificados na Formação Irati (Permiano) na borda setentrional da bacia do Paraná (MT, GO). Anais da Academia Brasileira de Ciências. 57: 117. 
FAIRCHILD, T. R.; SUBACIUS, S. M. R.; 1986. Microfossils associated with silicified Stratifera undata Komar 1966 from the late Proterozoic Bambui Group, south-central Brazil.. Precambrian Research. 33: 323-339.

FAURE, K.; COLE, D. 1999. Geochemical evidence for lacustrine microbial blooms in the vast Permian Main Karoo, Paraná, Falkland Islands and Huab basins of southwestern Gondwana. Palaeogeography, Palaeoclimatology, Palaeoecology. 152: 189-213.

FOSTER, C. B.; REED, J. D.; WICANDER, R. 1989. Gloeocapsomorpha prisca Zalessky 1917: A new study. Part I: Taxonomy, geochemistry, and paleoecology. Geobios. 22: 735-759.

FOSTER, C. B.; REED, J. D.; WICANDER, R. 1990. Gloeocapsomorpha prisca Zalessky 1917: A new study. Part II: Origin of kukersite, a new interpretation. Geobios. 22: 735759.

FOWLER, M. G.; STASIUK, L. D.; HEARN, M.; OBERMAJER, M. 2004. Evidence for Gloeocapsomorpha prisca in Late Devonian source rocks from southern Alberta, Canada. Organic Geochemistry. 35: 425-441.

FRANCIS, S.; MARGULIS, L.; BARGHOORN, E. S. 1978. On the experimental silicification of microorganisms, II. On the time of appearance of eukaryotic organisms in the fossil record. Precambrian Research. 6: 65-100.

FRIEDMANN, E. I.; 1982. Endolithic microorganisms in the Antarctic cold desert. Science. 215: $1045-1053$.

GAUCHER, C.; SPRECHMANN, P.; SCHIPILOV, A. 1996. Upper and Middle Proterozoic sedimentary sequences of the Nico Pérez Terrane of Uruguay: Lithostratigraphic units, paleontology, depositional environment and correlations. Neues Jahrbuch für Geologie und Paläontologie, Abhandlungen, 199: 339-367.

GOLUBIĆ, S.; BARGHOORN, E. S. 1977. Interpretation of microbial fossils with special reference to the Precambrian. In: FLÜGEL, E. (ed.). Fossil Algae, Recent Results and Developments. Berlin-Heidelberg (Springer). 1-14.

GREEN, J. W.; KNOLL, A. H.; SWETT, K. 1989. Microfossils from silicified stromatolitic carbonates of the Upper Proterozoic Limestone-Dolomite 'Series', central East Greenland. Geological Magazine 126: 567-585.

GREENSMITH, J. T. 1989. Siliceous deposits. In: FOLK R. L. (ed.) Petrology of Sedimentary Rocks. Academic Press. London. 2: 153-163. 
GRICE, K.; SCHOUTEN, S.; BLOZZER, P.; DERENNE, C. L.; NISSENBAUM, A.; DAMSTÉ, S. J. S. 2003. Structural and isotopic analysis of kerogens in sediments rich in free sulfurised Botryococcus braunii biomarkers. Organic Geochemistry. 34: 471-482.

GRICE，K.; SCHOUTEN，S.; NISSENBAUM，A.; CHARRACH，J.; SINNINGHE DAMSTÉ, J. S. 1998. A remarkable paradox: freshwater algal (Botryococcus braunii) lipids in an ancient hypersaline euxinic ecosystem. Organic Geochemistry. 28: 195-216. HACHIRO, J. 1991. Litotipos, associações faciológicas e sistemas deposicionais da Formação Irati no Estado de São Paulo. Universidade de São Paulo, Instituto de Geociências, Dissertação de Mestrado, 175p. Inédita.

HACHIRO, J. 1997. O Subgrupo Irati (Neopermiano) da Bacia do Paraná. Universidade de São Paulo, Instituto de Geociências, Tese de Doutoramento, 196 p. Inédita.

HACHIRO J.; COIMBRA, A. M.; MATOS, S. L. F. 1993. O caráter cronoestratigráfico da unidade Iratí. $1^{\circ}$ Simpósio sobre cronoestratigrafia da Bacia do Paraná - IGCE/UNESP, Resumos, 62-63.

HART, G. F. 1971. The Gondwana Permian palynoflora. Anais da Academia Brasileira de Ciências. 43: 145-185.

HENLEY, W. J.; MAYOR, K. M.; HIRONAZA, J. L. 2002. Response to salinity and heat stress in two halotolerant chlorophyte algae. Journal of Phycology. 38: 757-766.

HESSE, R. 1990a. Origin of chert: Diagenesis of biogenic siliceous sediments. In: McILREATH, I. A.; MORROW, D.W. (eds.). Diagenesis. Geological Association of Canada, Geoscience Canada Reprint Series. 4: 227-251.

HESSE, R. 1990b. Silica diagenesis: Origin of inorganic and replacement cherts. In: McILREATH, I. A.; MORROW, D.W. (eds.). Diagenesis. Geological Association of Canada, Geoscience Canada Reprint Series. 4: 253-275.

HOFMANN, H. J. 1976. Precambrian microbiota, Belcher Islands, Canada: significance and systematics. Journal of Paleontology. 50: 1040-1073.

HORODYSKI, R. J.; DONALDSON, J. A. 1983. Distribution and significance of microfossils in chert of the middle Proterozoic Dismal Lakes Group, District of MacKenzie, Northwest Territories, Canada. Journal of Paleontology 57: 271-288.

HORODYSKI, R. J.; VONDER HAAR, S. 1975. Recent calcareous stromatolites from Laguna Mormona (Baja Califórnia) Mexico. Journal of Sedimentary Petrology. 45 (4): 894-906. 
HORODYSKI, R. J.; BLOESER, B.; VONDER HAAR, S. 1977. Laminated algal mats from a coastal lagoon, Laguna Mormona, Baja California, Mexico. Journal of Sedimentary Petrology. 47 (2): 680-696.

HORSTHEMKE, E.; LEDENDECKER, S.; PORADA, H. 1990. Depositional environments and stratigraphic correlation of the Karroo Sequence in northwestern Damaraland. Communications of the Geological Survey of Namibia. 6: 63-73.

ILER. R.K. 1979. The chemistry of silica. New York, John Wiley \& Sons. 687p.

IMBRIE, J. 1959. Biometrical methods in the study of invertebrate fossils. Bulletin of American Museum of Natural History. 1082: 214-252.

JONES, B.; RENAUT, R. W.; ROSEN, M. R. 2003. Silicified microbes in a geyser mound: the enigma of low-temperature cyanobacteria in a high-temperature setting. Palaios. 18: 87-109.

KIDDER, D. L.; ERWIN, D. H. 2001. Secular distribution of biogenic silica through the Phanerozoic: Comparison of silica-replaced fossils and bedded cherts at the series level. Journal of Geology. 109: 509-522.

KNAUTH, L. P.; LOWE, D. R. 2003. High Archean climatic temperature inferred from oxygen isotope geochemistry of chert in the $3.5 \mathrm{Ga}$ Swaziland Supergroup, South Africa. Geology Society of America Bulletin. 155: 566-580.

KNAUTH, M.; KEENER, J. B.; GIESKES, J. M. 1977. Diagenesis of siliceous oozes. I. Chemical controls on the rate of opal-A to opal-CT transformation: an experimental study. Geochimica et Cosmochimica Acta. 41: 1004-1059.

KNOLL, A. H. 1982. Microfossils from the late Precambrian Draken Conglomerate, Ny Friesland, Svalbard. Journal of Paleontology. 56: 755-790.

KNOLL, A. H. 1996. Archean and Proterozoic paleontology. In: JANSONIUS, J.; McGREGOR, D. C. (eds.). Palynology: Principles and Applications. American Association of Stratigraphic Palynological Foundation, Dallas. 51-80.

KNOLL, A. H.; BARGHOORN, E. S. 1977. Archean microfossils showing cell division from the Swaziland system of South Africa. Science. 198: 396-398.

KNOLL, A. H.; GOLUBIĆ, S. 1979. Anatomy and taphonomy of a Precambrian algal stromatolite. Precambrian Research. 10: 115-151.

KNOLL, A. H.; SWETT, K.; MARK, J. 1991. Paleobiology of Neoproterozoic tidal flat/lagoonal complex: the Draken Conglomerate Formation, Spitsbergen. Journal of Paleontology. 65: 531-569. 
KOMÁREK, J. 2003. Coccoid and colonial cyanobacteria. In: WEHR, J. D.; SHEATH, R. G. (eds.). Freshwater Algae of North America - Ecology and Classification. Academic Press. San Diego. 117-196.

KOMÁREK, J.; HAUER T. 2004. CyanoDB.cz - On-line database of cyanobacterial genera. - http://www.cyanodb.cz.

KREMER, B. 2006. Mat-forming coccoid cyanobacteria from early Silurian marine deposits of Sudetes, Poland. Acta Palaeontologica Polonica 51 (1): 143-154.

KUMAR, S.; SRIVASTAVA, P. 1992 Middle to Late Proterozoic microbiota from the Deoban Limestone, Garhwal Lesser Himalaya, India, Precambrian Research. 56: 291318.

MAGALHÃES, M. N.; LIMA, A. C. P. 2001. Noções de probabilidade e estatística. IMEUSP. São Paulo. 3: 391 pp.

MALIVA, R. G.; KNOLL, A. H.; SIEVER, R. 1989. Secular change in chert distribution: A reflection of evolving biological participation in the silica cycle. Palaios. 4: 519-532.

MENDES, J. C.; PETRI, S. 1975. Pré-Cambriano. In: Geologia histórica. Enciclopédia Brasileira, Biblioteca Universitária, Geociências/Geologia. 26-33.

MEZZALIRA, S. 1971. Contribuição ao conhecimento da geologia da subsuperfície e da paleontologia da Formação Iratí no Estado de São Paulo. Anais da Academia Brasileira de Ciências. 43: 273-336.

MILANI, E. J.; FRANÇA, A. B.; SCHNEIDER, R. L. 1994. Bacia do Paraná. Boletim de Geociências PETROBRÁS. 8: 69-82.

MILANI, E. J.; ZALÁN, P. V. 1999. An outline of geology and petroleum systems of the Paleozoic interior basins of South America. Episodes 22: 199-205.

MILANI, E. J. ; THOMAZ FILHO, A. 2000. Sedimentary Basins of South America. In: $31^{o}$ International Geological Congress. Tectonic Evolution of South America. Rio de Janeiro. International Geological Congress. (1) p. 389-449.

MUIR; M. D. 1974. Microfossils from the middle Precambrian McArthur Group, Northern Territory, Australia. Origins of Life and Evolution of Biospheres. 5: 105-118.

MUSSA, D. 1982. Lignitafoflora permiana da Bacia do Paraná, Brasil (Estados de São Paulo e Santa Catarina). Universidade de São Paulo, Instituto de Geociências, Tese de Doutoramento. 463 p. Inédita.

NOZAK, H. 2003. Flagellated green algae. In: WEHR, J.D.; SHEATH, R. G. (eds.) Freshwater Algae of North America - Ecology and Classification. Academic Press. San Diego. 1: 225-252. 
NÜBEL, U.; BATESON, M. M.; MADIGAN, M. T. KÜHL, M.; WARD; D. M. Spatial scale and the diversity of benthic cyanobacteria and diatoms in a salina. Hydrobiologia. 401: 199-206.

NYBERG. A. V.; SCHOPF, J. W. 1984. Microfossils in stromatolitic cherts from the Upper Proterozoic Min'Yar Formation. Journal of Paleontology. 58: 738-772.

OEHLER, D. K. 1977. Pyrenoid-like structures in Late Precambrian algae from the Bitter Springs Formation of Australia. Journal of Paleontology. 51: 885-901.

OEHLER, D. K.; OEHLER, J. H.; STEWART, A. J. 1979. Algal fossils from a late Precambrian, hypersaline lagoon. Science. 205: 388-390.

OEHLER, J. H. 1976. Experimental studies in Precambrian paleontology: structural and chemical changes in blue-green algae during simulated fossilization in synthetic chert. Bulletin of the Geological Society of America. 87: 117-129.

OELOFSEN, B. W.; ARAÚJO, D. C. 1987. Mesosaurus tenuidens and Stereosternum tumidum from the Permian Gondwana of both Southern African and South America. South African Journal of Science. 83: 370-372.

OREN, A. 2000. Salts and Brines. In: WHITTON, B. A.; POTT, M. (Eds.). The Ecology of Cyanobacteria: Their Diversity in Time and Space. Kluwer Academic Publishers. Netherlands. 282-301p.

OREN, A. 2005. A hundred years of Dunaliella research: 1905-2005. Saline Systems. 2: 114.

ORUÉ, D. 1996. Síntese da geologia do Paraguai Oriental, com ênfase para o magmatismo alcalino associado. Universidade de São Paulo, Instituto de Geociências. Dissertação de Mestrado. 100p. Inédita.

PAERL, H. W. 1996. Microscale physiological and ecological studies of aquatic cyanobacteria: Macroscale implications. Microscopy Research and Technique. 33: $47-$ 72.

PAULIPETRO. 1981. In: Relatório de Atividades 1979/1981 da Paulipetro. Consórcio CESP/IPT. 59 p.

PETRI, S., FULFARO, V. J. 1983. Geologia do Brasil (Fanerozóico) - São Paulo: T. A. Queiroz - EDUSP, São Paulo. 631 p.

REED, J. D.; ILLICH, H. A.; HORSFIELD, B. 1986. Biochemical evolutionary significance of Ordovician oils and their sources. Organic Geochemistry. 10: 347-358.

REVIERS, B. 2006. Biologia e Filogenia das Algas. Porto Alegre: Artmed. 208p. 
RICCOMINI, C. 1992 Estilos estruturais da região do alto estrutural de Pitanga, Bacia do Paraná, SP. Boletim do Instituto de Geociências/ IGc-USP. 12: 93-94.

RIECH, V.; VON RAD; U. 1979. Silica diagenesis in the Atlantic Ocean: diagenetic potential and transformations. In: TALWANI, M.; HAY, W.; RYAN, W. B. F. (eds) Deep Drilling Results in the Atlantic Ocean: Continental Margins and Paleoenvironment. American Geophysic Union, Washington (D.C.). 3: 315-340.

ROTHSCHILD, L.J.; GIVER, L. J.; WHITE, M. R.; MANCINELLI, R. L. 1994. Metabolic activity of microorganisms in evaporites. Journal of Phycology. 30: 431-438.

SANTOS R. V.; SOUZA, P. A.; ALVARENGA, C. J. S.; DANTAS, E. L.; PIMENTEL, M. M.; OLIVEIRA, C. G.; LAURY, M. A. 2006. Shrimp U-Pb zircon dating and palynology of bentonitic layers from the Permian Irati Formation, Paraná Basin, Brazil. Gondwana Research. 9: 456-463.

SCHMIDT, S. 2004. The petroleum potential of the passive continental margin of SouthWestern Africa - A basin modeling study. 161p. Inédita.

SCHOPF, J. W. 1968. Microbiota of the Bitter Springs Formation, Late Precambrian, central Australia. Journal of Paleontology. 42: 651-688.

SCHOPF, J.W. 1992a. Proterozoic prokaryotes: affinities, geologic distribution, and evolutionary trends. In: SCHOPF, J. W.; KLEIN, C. (eds.) The Proterozoic Biosphere: a Multidisciplinary Study. Cambridge University Press. New York. 195-218.

SCHOPF, J. W. 1992b. Informal revised classification of Proterozoic microfossils. In: SCHOPF, J. W.; KLEIN, C. (eds.). The Proterozoic Biosphere: a Multidisciplinary Study. Cambridge University Press. New York. 1119-1167.

SCHOPF, J. W. 1995. Ritmo e modo da evolução microbiana pré-cambriana. Estudos Avançados. 23: 195-216.

SCHOPF, J. W. 2000. The fossil record: tracing the roots of the cyanobacterial lineage. In: WHITTON, B. A.; POTT, M. (eds.). The Ecology of Cyanobacteria: Their Diversity in Time and Space. Kluwer Academic Publisher. Cambridge. 13-35.

SCHOPF, J. W.; BLACIC, J. M. 1971. New microorganisms from the Bitter Springs Formation (Late Precambrian) of the north-central Amadeus Basin, Australia. Journal of Paleontology. 45: 925-961.

SERGEEV, V. N. 1994. Microfossils in cherts from the Middle Riphean (Mesoproterozoic) Avzyan Formation, southern Ural Mountains, Russian Federation. Precambrian Research. 65: 231-254. 
SERGEEV, V. N. 2001. Paleobiology of the Neoproterozoic (Upper Riphean) Shorika and Burovaya silicified microbiotas, Turukhansk Uplift, Siberia. Journal of Paleontology. 75: 427-448.

SERGEEV, V. N.; KNOLL, A. H.; GROTZINGER, J. P. 1995. Paleobiology of the Mesoproterozoic Billyakh. Group, Anabar Uplift, Northern Siberia. Journal of Paleontology. 69: 1-37.

SHUBERT, L. E. 2003. Nonmotile coccoid and colonial green algae. In: WEHR, J.D.; SHEATH, R. G. (eds.). Freshwater Algae of North America - Ecology and Classification. Academic Press. New York. pp. 253-309.

SILVA, Z. C. C.; CORNFORD , C. 1985. The kerogen type, depositional and maturity of the Iratí Shale, Upper Permian of Paraná Basin, Southern Brazil. Organic Geochemistry. 8: 399-411.

SILVA, L. H. S.; DAMAZIO, C. M., IESPA, A. A. C. 2005. Identificação de cianobactérias em sedimento da Lagoa Pitanguinha, Estado do Rio de Janeiro, Brasil. Anuário do Instituto de Geociências - UFRJ. (28) 92-100.

SIMONETTI, C.; FAIRCHILD, T. R. 2000. Proterozoic microfossils from subsurface siliciclastic rocks of the São Francisco Craton, south-central Brazil. Precambrian Research. 103: 1-29.

SONEA, S.; PANISSET, M. 1983. The New Bacteriology. In: Boston. 140p.

SOUZA, P. A.; MARQUES-TOIGO, M. 2003. An overview on the palynostratigraphy of the Upper Paleozoic strata of the Brazilian Paraná Basin. Revista del Museo Argentino de Ciencias Naturales. 5: 205-214.

RODRIGUES, S. M.; AMARAL, S. E. 1983. Estudos biogeoquímicos da matéria orgânica em folhelhos pirobetuminosos próximos a soleiras de diabásio - Formação Irati, SP. Anais da Academia Brasileira de Ciências. 55: 45-53.

SUGUIO, K.; FAIRCHILD, T. R.; SOUSA, S. H. M. 1985. Novas descobertas de estromatólitos na Formação Corumbataí (Permiano) em Santa Rosa do Viterbo (SP) e seus significados paleoambientais. Boletim de Resumos do $5^{\circ}$ Simpósio Regional de Geologia da Sociedade Brasileira de Geologia - São Paulo, p. 12.

SUGUIO, K.; SOUZA, S. H. M. 1985. Restos de mesossaurídeos na Formação Corumbataí, Permiano da Bacia do Paraná no Estado de São Paulo. Anais da Academia Brasileira de Ciências. 57: 339-347.

TAPPAN, H. 1980. The Paleobiology of Plant Protists. W. H. Freeman and Company. San Francisco. 1050 pp. 
TAYLOR, N. T.; HASS, H.; KERP, H. 1997. A cyanolichen from the Lower Devonian Rhynie Chert. American Journal of Botany. 84: 992-1104.

THOMAS, D. J.; SULLIVAN, S. L.; PRICE, A. L.; ZIMMERMAN, S. M. 2005. Common freshwater cyanobacteria grown in $100 \% \mathrm{CO}_{2}$. Astrobiology. 5: 66-74.

TOBIN, Z. J. 2004. A survey of Paleozoic microbial fossils in chert. Sedimentary Geology. 168: 97-107.

TSCHUDY, R. H. 1961. Palynomorphs as indicators of facies environments in Upper Cretaceous and Lower Tertiary strata. $16^{\circ}$ Annual Field Conference. Wyoming Geology Association Guidebook. Colorado and Wyoming. 16. 16: 53-59.

ULUKANLI, Z.; DIĞRAK, M., 2002. Alkaliphilic micro-organisms and habitats. Turkish Journal of Biology. 26: 181-191.

UESUGUI, N. 1979. Palinologia: técnicas de tratamento de amostras. Boletim Técnico da Petrobrás. Rio de Janeiro. 22: 229-240.

VERSTEEGH, G. J. M.; BLOKKER, B. 2004. Resistant macromolecules of extant and fossil microalgae. Phycological Research. 52: 325-339.

VINCENT, W. F.; JAMES, M. R. 1996. Biodiversity in extreme aquatic environments: lakes, ponds and streams of the Ross Sea sector, Antarctica. Biodiversity and Conservation. 5: 1451-1471.

WAKE, L. V. 1983. Characteristics of resting state colonies of the alga Botryococcus braunii obtained from a bloom of the organism. Australian Journal of Botany.31: 605614.

WEHR, J.D.; SHEATH, R. G. 2003. Freshwater habitats of algae. In: WEHR, J.D. \& SHEATH, R. G. (Eds.) Freshwater Algae of North America - Ecology and Classification. Academic Press. New York. 11- 45.

WICANDER, R.; PLAYFORD, G.; ROBERSTON, E. B. 1999. Stratigraphic and paleogeographic significance of an upper Ordovician acritarch flora from the Maquoketa shale, northeastern Missouri, USA. Journal of Paleontolology, 73 (Memoir 51): 1-38.

WOESE, C. R.; FOX, G. E. 1977. Phylogenetic structure of the prokaryotic domain: the primary kingdoms. Proceedings of the National Academy of Sciences of the United States of America. 74: 5088-5090.

YAMAMOTO, J. K.; MONTANHEIRO, T. J.; HACHIRO, J. 2004. Trípoli no Subgrupo Irati: a ocorrência de Ipeúna, Estado de São Paulo. Revista Brasileira de Geociências. 34: 35-40. 
ZALÁN, P. V.; WOLF, S.; CONCEIÇÃO, J. C. J.; MARQUES, A.; ASTOLFI, M. A. M.; VIEIRA, L. S.; APPI, V. T.; ZANOTTO, O. A. 1990 - Bacia do Paraná. In: GABAGLIA, G. P. R.; MILANI, E. J. (coordenadores) - Origem e Evolução de Bacias Sedimentares. SNE-PETROBRÁS. 135-168.

ZANG, Y. 1988. Proterozoic stromatolitic micro-organisms from Hebei, north China: Cell preservation and division. Precambrian Research. 38: 165-175.

ZOHARY, T.; BREEN, C. M.. 1989. Environmental factors favouring the formation of Microcystis aeruginosa hyperscums in a hypertrophic lake. Hydrobiologia. 178: 179192. 